\title{
An Innovative Approach to Solving the Ergonomic Problem: Products' Size Adjustment
}

\author{
Ana Velkova*
}

Faculty of Mechanical Engineering, Industrial Design, Ss. "Cyril and Methodius University" of Skopje, Skopje, Republic of Macedonia

\begin{abstract}
Citation: Velkova A. [An Innovative Approach to Solving the Ergonomic Problem: Products' Size Adjustment]. SEE $J$ Archit Des. 2018 May 10; 10035. [MSc] [Mach
http://dx.doi.org/10.3889/seejad.2018.10035

Keywords: Bionic design; Ergonomic design; Eco-design; Size adjuctment; Child bike seat; Contemporary materials *Correspondence: Ana Velkova. Faculty of Mechanical University" of Skopje, Skopje, Republic of Macedonia. Email: velkova_ana@yahoo.com

Received: 06-Apr-2018. Revised: 08-May-2018; Accepted: 10-May-2018; Published: 11-May-2018

Copyright: $\odot 2018$ Ana Velkova. This is an open-access article distributed under the terms of the Creative use, distribution, and reproduction in any medium, provided the original author and source are credited.

Competing Interests: The author has declared that no competing interests exist
\end{abstract}

\section{Abstract}

The use of ergonomic principles is imperative for the design of each contemporary product and its success on the market. Despite the common association of ergonomics with comfort, especially with products related to sitting, this master thesis has its focus on products with adjustable sizes, setting a main goal to make this product durable and adaptable to various physical differences between the users (children at different ages).

In this thesis, the use of bionic methods and principles provide innovative insight and solution to the main issue at hand, adapting the seat to different sizes with application of layers of material. In shaping the layers of material, a fractal design is used, an algorithm method that creates a mathematical dependence in solving the specific problem of different sizes. In this case it solves the correlation between the sizes of layers of the material.

The results of these interdisciplinary researches are implemented and evaluated through a design of a child bike seat, by which they are turned into an ecological, recyclable and modern product. 
Универзитет „Св. Кирил и Методиј“ во Скопје

Машински факултет - Скопје

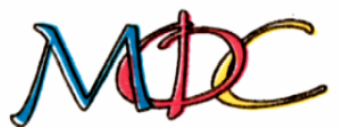

Постдипломски студии - Индустриски дизајн и маркетинг

\title{
Иновативен пристап во решавањето на ергономскиот проблем: прилагодување на големината на производите
}

\author{
Интердисциплинарен проект \\ Магистерска работа
}

Ментор:

Кандидат:

проф. д-р Софија Сидоренко

дипл. инж. инд. Ана Велкова

Скопје, мај 2017 
Ментор:

Членови на комисијата:

Дата на одбрана:

Дата на промоција: проф. д-р Софија Сидоренко

Машински факултет - Скопје

проф. д-р Ристо Ташевски

Машински факултет - Скопје

проф. д-р Јасмина Чалоска

Машински факултет - Скопје 
Голема благодарност до ...

Mоите родители, за нивната љубов и несебична поддршка во текот на целото мое образование, за сите совети, критики и стари решени збирки со задачи;

Mојот ментор профр. Сидоренко, која успешно ми го пренесе прво интересот кон производите инспирирани од природата, а потоа и знаењето потребно за остварување на мојата замисла за бионички дизајн, профресорка која особено ја почитувам затоа што секогаш имаше разбирање за се;

Мојот син Марко, без кој никогаш немаше да бидам мотивирана за да стигнам каде што сум денес. Овој труд му го посветувам нему. 
Кандидат:

\section{Ана Велкова}

Tема:

\section{Иновативен пристап во решавањето на ергономскиот проблем: прилагодување на големината на производите.}

\section{Апстракт:}

Примената на ергономските принципи претставува императив во дизајнот на секој современ производ од кој директно зависи неговиот успех на пазарот. Иако најчесто ергономијата се поврзува со удобноста, особено кај производите наменети за седење, во овој магистерски труд е ставен акцент на производи со прилагодливи големини, со цел да бидат употребливи подолг временски период за деца кои растат, како и за прилагодување кон различните фризички карактеристики на повеќе корисници (деца) кои го употребуваат истиот производ.

Во оваа магистерска работа, примената на бионичките методи и принципи обезбедија иновативен пристап во решавањето на проблемот прилагодување за различни големини на производите со помош на слоеви од материјал. Во обликувањето на слоевите материјал е применет фрактален дизајн, алгоритамски метод кој креира математичка зависност во решавањето на специфичниот проблем на различни големини. Во овој случај тоа е зависноста меѓу димензиите на слоевите од материјалот.

Збирните резултати од овие интердисциплинарни истражувања се применети и проверени преку дизајн на детско седиште за велосипед, со што истите се преточени во дизајн на еколошки, рециклабилен и модерен производ.

Клучни зборови: бионички дизајн, ергономски дизајн, еко дизајн, прилагодување на големини, детско седиште за велосипед, современи материјали 
Candidate:

\title{
Ana Velkova
}

Thesis:

\section{An innovative approach to solving the ergonomic problem: products' size adjustment.}

\begin{abstract}
:
The use of ergonomic principles is imperative for the design of each contemporary product and its success on the market. Despite the common association of ergonomy with comfort, especially with products related to sitting, this master thesis has its focus on products with adjustable sizes, setting a main goal to make this product durable and adaptable to various physical differences between the users (children at different ages).

In this thesis, the use of bionic methods and principles provide innovative insight and solution to the main issue at hand, adapting the seat to different sizes with application of layers of material. In shaping the layers of material a fractal design is used, an algorithm method that creates a mathematical dependence in solving the specific problem of different sizes. In this case it solves the correlation between the sizes of layers of the material.

The results of these interdisciplinary researches are implemented and evaluated through a design of a child bike seat, by which they are turned into an ecological, recyclable and modern product.
\end{abstract}

Key words: bionic design, ergonomic design, eco-design, size adjuctment, child bike seat, contemporary materials. 


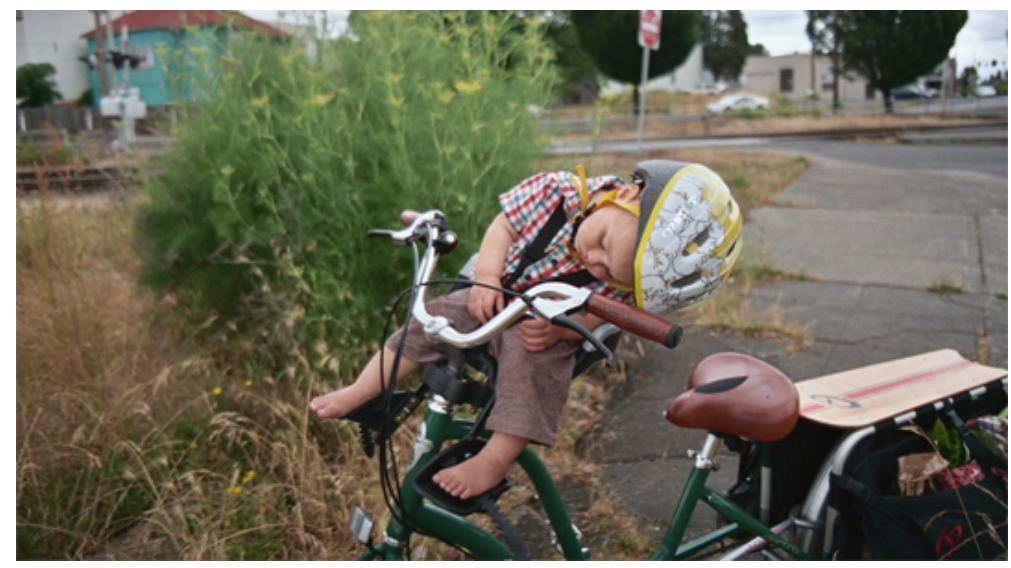

\section{Содржина}

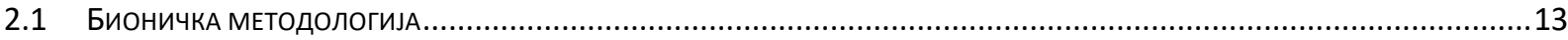

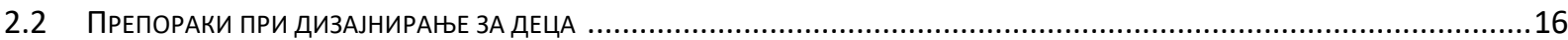

2.3 ЕРГОНОМСКИ ИСТРАЖУВАҢА ЗА ПРИЛАГОДУВАњЕ НА ГОЛЕМИНИТЕ НА ПРОИЗВОДИТЕ СПОРЕД ГОЛЕМИНАТА НА КОРИСНИКОт

2.4 ЗАКЛУЧОЦИ ОД ИСТРАЖУВАњЕТО …………………...........................................................................20

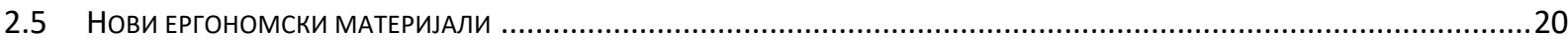

2.6 НЕКОЛКУ ПРИМЕРИ НА ПОДОБРУВАҢЕ НА ЕРГОНОМСКИОТ ДИЗАЈН НА ПРОИЗВОДИТЕ СО УПОТРЕБА НА НОВИ МАТЕРИЈАЛИ

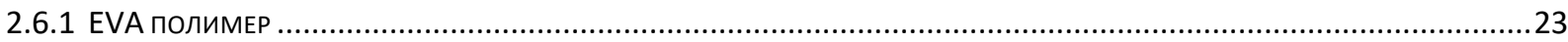

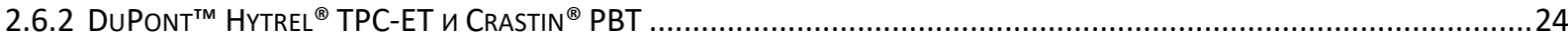

2.7 ЗАКЛУЧОК ОД ИСТРАЖУВАњЕТО

3 АНАЛИЗА НА ПАЗАРОТ - ПОСТОЕЧКИ ВЕЛОСИПЕДСКИ СЕДИШТА ЗА ПРЕВОЗ НА ДЕЦА

3.1 ОСНОВНИ ВИДОВИ НА ДЕТСКИ СЕДИШТА

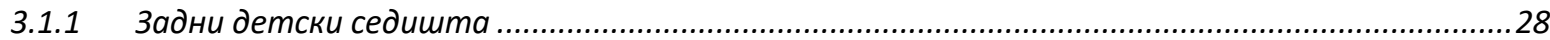

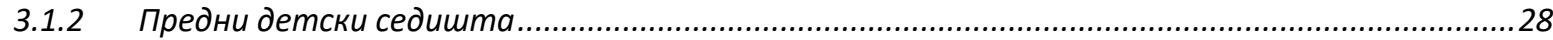

3.2 ПРЕДНОСТИ И НЕДОСТАТОЦИ НА ОСНОВНИТЕ ВИДОВИ НА ДЕТСКИ СЕДИШТА ....................................................29

3.3 ПРЕГЛЕД НА НАЈПОПУЛАРНИТЕ ВЕЛОСИПЕДСКИ СЕДИШТА ЗА ПРЕВОЗ НА ДЕЦА ..................................................30

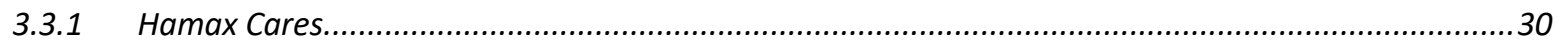

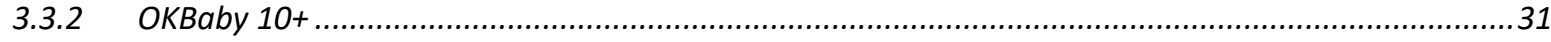

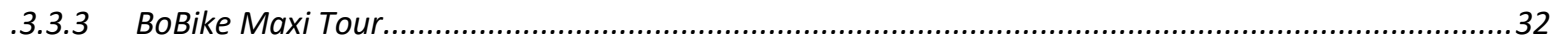




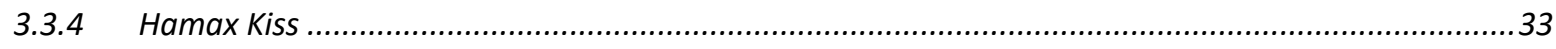

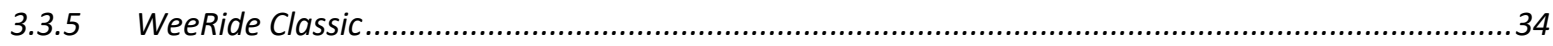

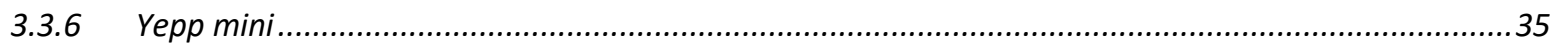

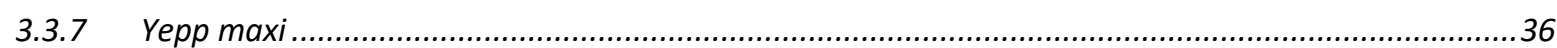

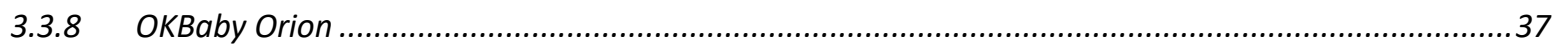

3.4 СПОРЕДБА НА РАЗЛИЧНИТЕ АЛТЕРНАТИВИ ...................................................... ERROR! BOOKMARK NOT DEFINED.

\section{4 ДЕФИНИРАЊЕ НА КАРАКТЕРИСТИКИТЕ НА НОВИОТ КОНЦЕПТ НА ВЕЛОСИПЕДСКО СЕДИШТЕ ЗА}

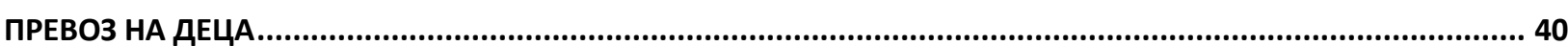

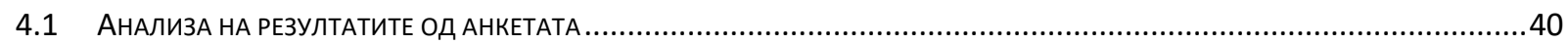

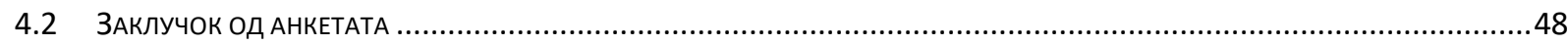

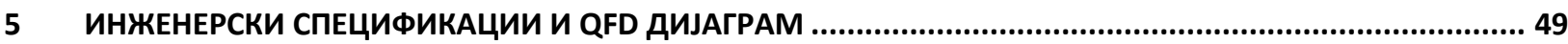

5.1 КОНЕЧНИ ЦЕЛИ ЗА ДИЗАЈН НА ВЕЛОСИПЕДСКО СЕДИШТЕ ЗА ПРЕВОЗ НА ДЕЦА ....................................................

6 АНТРОПОМЕТРИСКИ МЕРКИ НЕОПХОДНИ ЗА ПРАВИЛНО ДИМЕНЗИОНИРАЊЕ НА СЕДИШТЕТО........ 52

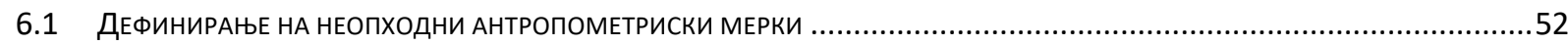

7 ЕРГОНОМСКА АНАЛИЗА НА УДОБНОСТА НА СЕДЕЊЕТО НА ПРОИЗВОДИ НАМЕНЕТИ ЗА ДЕЦА .......... 56

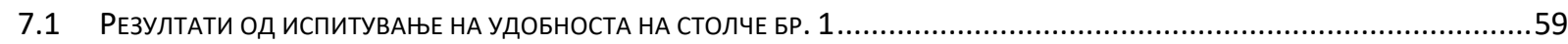

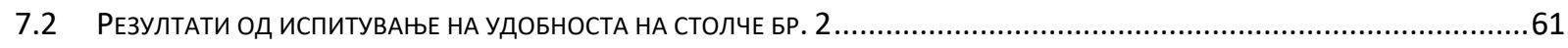

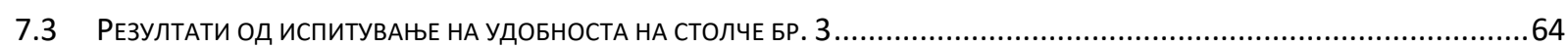

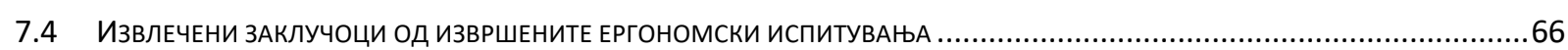

8 ИЗВЛЕКУВАЊЕ ИНСПИРАЦИЈА ЗА РЕШАВАЊЕ НА ОДДЕЛНИТЕ ЗАДАДЕНИ ЦЕЛИ ............................. 67

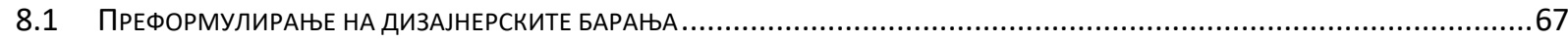

8.2 ИЗНАОЃАЊЕ СООДВЕТНОСТ ПОМЕЃУ ИНЖЕНЕРСКИТЕ ПРОБЛЕМИ И РЕШЕНИЈА ПОНУДЕНИ ОД ПРИРОДАТА .....................68

8.3 ПОДЕТАЛНА АНАЛИЗА НА СЕЛЕКТИРАНИТЕ РЕШЕНИЈАТА ОД ПРИРОДАТА ..............................................................

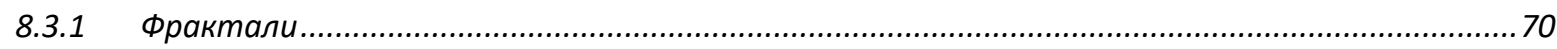

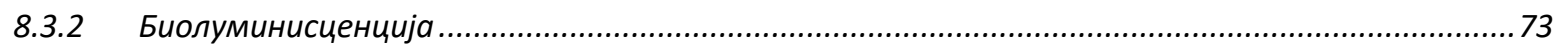

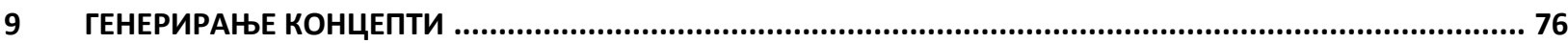

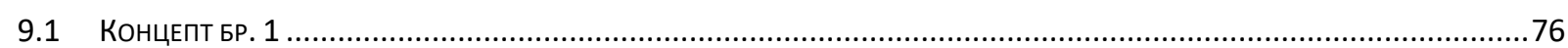

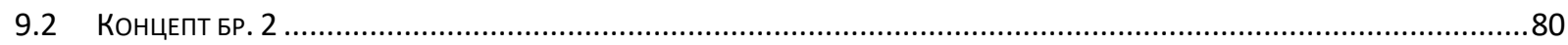

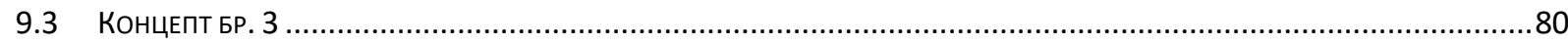

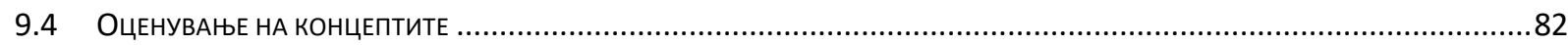

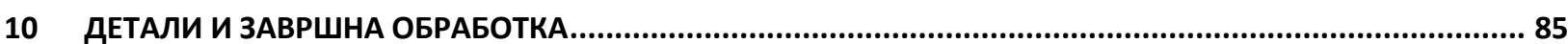

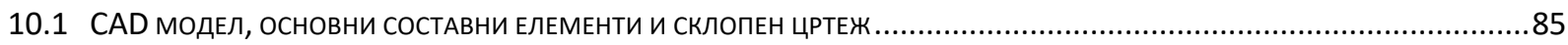

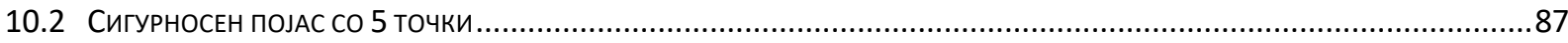




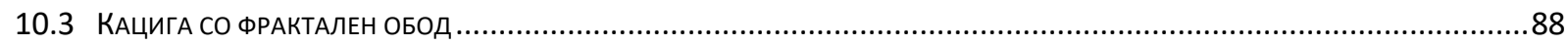

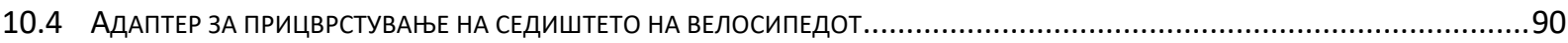

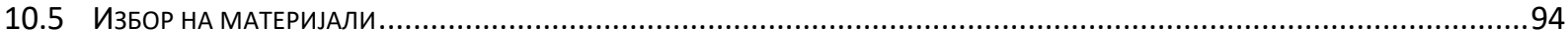

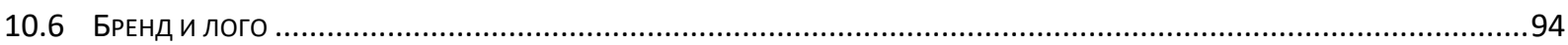

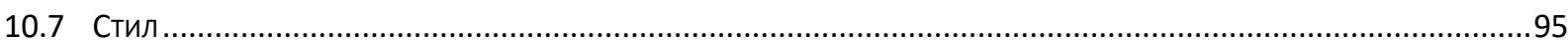

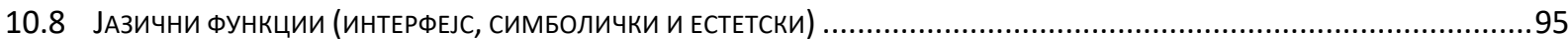

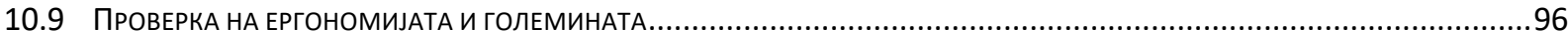

11 ИЗРАБОТКА НА МАКЕТА

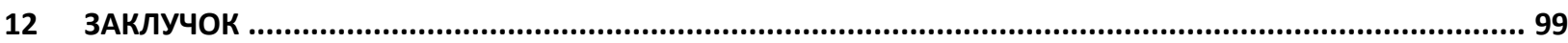

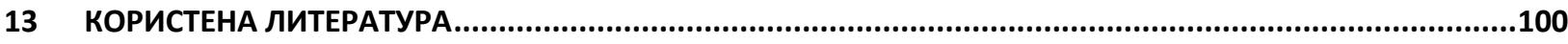

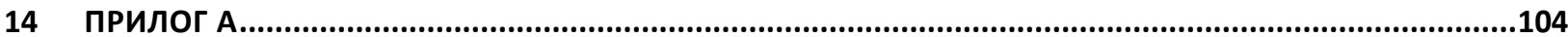




\section{1 Вовед}

Примената на ергономските принципи претставува императив во дизајнот на секој современ производ од кој директно зависи неговиот успех на пазарот. Главната цел на овој магистерски труд е да се даде придонес кон решавањето на конкретен ергономски проблем - прилагодливост на големините на производите заради соодветност со возраста и разликите во фризичките карактеристики на корисниците. Воведувањето на слоевитост во градбата на производите заради решавање на овој проблем е инспириран од френомени во природата.

Во последно време се поголем тренд станува еко дизајнот, масовното производство по мерка, како и намалувањето на штетното влијание врз животната средина. Поради тоа, се повеќе се става акцент на велосипедот како превозно средство кое не испушта штетни издувни гасови, а влијае добро и на здравјето и општата спортска кондиција бидејќи како „гориво“ ги користи масните наслаги на човекот.

Притоа, радува фактот што во последниве неколку години се повеќе луѓе кај нас се одлучија да го избегнат градскиот метеж со тоа што станаа велосипедисти. Велосипедот се користи како превоз до работното место или училиштето, рекреативно возење на кејот на Вардар, малку поекстремно спуштање по козјите патеки на Водно, или за некоја од нашите многубројни cross-country велосипедски тури низ Македонија.

За тоа дека на подобро оди ситуацијата со велосипедизмот и свесноста на народот говори и фактот што во последно време се отворија и многу нови продавници- увозници и професионални сервисери за велосипеди кои до пред неколку години не постоеја во Скопје- опремени со марки како Cube, KTM, Specialized, Giant итн. Фактот што овие велосипеди достигнуваат цени од неколку стотици до неколку илјади евра (со подеднакво скапо одржување и делови) доволно говори за желбата на Македонците и покрај лошата економска состојба во земјата, да инвестираат во квалитетна спортска опрема, односно велосипед со пренос кој максимално го искористува напорот на возачот и не ги оптоварува зглобовите непотребно, а воедно и нуди задоволство при возењето 
како начин на ослободување од секојдневниот стрес на кој сме изложени во околината.

Во овој контекст посебно ранлива група се децата, а нивната безбедност на велосипед - како во сообраќајот, така и во природа е најважна за секој родител. Иако веќе постојат многубројни различни варијанти на детски велосипеди, сепак повеќето се наменети за деца над 6 години, со оглед на нервно-моторната развиеност и контролата која е потребна за возење. Оттука се јавува и потребата за квалитетно детско седиште за велосипед во кое тие би ги сместувале децата со доверба од аспект на безбедност, ергономија, материјалите кои се употребени, итн.

На пазарот веќе постојат голем број понудени велосипедски седишта за превоз на деца. Повеќето варијанти на светскиот пазар се делат на две групи: првите смеат да се користат од 9 месеци, кога детето е веќе способно само да седи, до 2 години. Вторите се наменети од 2 до 5 години.

Мојата главна цел во овој магистерски труд е се обидам да најдам дизајнерско решение за седиште кое би можело да се користи во подолг временски период, со можност за прилагодување на големината во зависност од растот на детето. Инспирација за решение на овој проблем најдов со помош на бионичката методологија. Имено, со примена на бионичката стратегија од дизајн проблем до решение во природата успеав да препознаам дека примената на слоеви, инспирирана од фракталите во природата, преку примерот на кромидот, е многу инвентивно решение. Овој пристап би овозможил со растот на детето да отпаѓa по еден слој од седиштето, така што ќе може да се користи од 0 до 5 години.

Секако дека реализацијата на еден ваков пристап во дизајнот не би била можна без примената на новите материјали и технологии, кои овозможуваат компензација меѓу потребите за крутост на конструкцијата и еластичноста на седиштето која треба да амортизира дел од нерамнините на патот, потоа потребата од стабилност на температурни разлики, а во исто време трајност и отпорност на атмосферски влијанија, со оглед на природата на примената на седиштето за велосипед.

Во оваа магистерска работа се применети современи методи на истражување и дизајнирање, карактеристични за областа на индустрискиот 
дизајн. Со примена на бионичка методологија се проучени принципи кои ги применила природата, со цел од нив да се извлечат суштинските карактеристики како одговор за решавање на проблемот на прилагодливост на големините. Од друга страна, заради ефикасност во примената, безбедноста и удобноста при седењето, применети се соодветни ергономски методи и антропометриски анализи.

Предложениот иновативен пристап во решавањето на проблемот на обезбедување различни големини на производите, инспириран од проучени принципи во природата, е применет и проверен преку дизајн на детско седиште за велосипед кое овозможува адаптибилност за различни големини кои ја следат возраста и големината на децата како корисници. На тој начин е потврден неговиот квалитет и неговата апликабилност за продолжување на периодот на примена на некои производи со што стануваат поекономични и поисплатливи. Конечна цел на овој труд е понудениот принцип да биде применлив и кај други производи за кои е неопходна прилагодливост на големината, или пак како инспирација за постигнување други видови адаптибилност со помош на слоеви. 


\section{2 Современи методологии во дизајнот на производи}

Дизајн методологиите се основни алатки во процесот на дизајнирање кои обезбедуваат насоки, цели и технички упатства за развој на еден производ".

Во истражувачкиот дел од оваа магистерска работа извршено е проучување на расположивата литература и научни трудови од областа на ергономијата, биониката, новите материјали и технологии, маркетиншките стратегии, а заклучоците подоцна се применети во дизајн на конкретен производ - велосипедско седиште за превоз на деца. Главна цел на оваа магистерска работа е истражување на ергономскиот принцип адаптибилност на големините на производите со цел да можат да се користат во подолг период поради промена на димензиите на корисниците, во кокретниот случај децата.

Проучувањето на ергономските методи обезбедува принципи кои овозможуваат дизајнирање на комфорен, функционален, фрлексибилен, безбеден производ, правилно димензиониран и лесен за ракување.

Биониката е релативно нова наука која наоѓа примена во различни сфери на дизајнот со цел да обезбеди инспирација од природата. Облиците, формите, механизмите и начините на фуннкционирање на природните системи се повеќе од фрасцинантни - само треба да се завртиме околу себе и ќе пронајдеме многу решенија на проблеми за кои не сме ни биле свесни дека постојат, а природата ги решила на генијален начин уште пред неколку милијарди години.

Следењето на новините во науката за материјалите и технологиите за нивна примена игра голема улога во чинот на инспирирање во рамките на процесот на дизајнирање. Обликувањето на производот $и$ неговите карактеристики се тесно поврзани со избраниот материјал. Токму затоа, информациите за новините во оваа област, како и познавањето на методите за правилен избор на материјал играат голема улога во процесот на дизајнирање.

Методите за маркетиншки испитувања овозможуваат преку анализа и анкетирање на можните корисници да се добие јасна слика за барањата на корисниците и оправданоста од потребата за развој на еден конкретен производ.

\footnotetext{
${ }^{1}$ Carlos A. M. Versos and Denis A. Coelho, (2011) A Bi-Directional Method for Bionic Design with Examples, Universidade da Beira Interior, Portugal
} 


\section{1 Бионичка методологија}

Биониката е релативно нова наука која наоѓа примена во различни сфери на дизајнот со цел да обезбеди инспирација од природата. Облиците, формите, механизмите и начините на функционирање на природните системи се повеќе од фасцинантни- само треба да се завртиме околу себе и ќе пронајдеме многу решенија на проблеми за кои не сме ни биле свесни дека постојат, а природата ги решила на генијален начин уште пред неколку милијарди години.

Многу истражувачи работеле на развивањето на стратегии и методи за развивање на нови производи инспирирани од природата. Бионичките методологии се водилки и основни алатки во процесот на дизајнирање, на кои дизајнерите можат да се потпрат кога се соочени со некој проблем, но тие сами по себе не гарантираат успех на дизајнираниот производ. ${ }^{2}$

Helms, Vattam и Goel предлагаат организиран пристап во бионичкиот дизајн, кој може да се примени и во двата случаја - на процес кој почнува со проблем и на процес кој почнува со решение/механизам од природата. Carlos A. M. Versos and Denis A. Coelho, од друга страна, советуваат двонасочен метод, каде на почетокот дизајнерот треба да се одбере една од двете насоки: од горе - надолу, кој започнува со технички проблем, а решението се бара во природните системи, и оддолу - нагоре, пристап кој започнува со биолошки френомен и се пренесува на потенцијално техничко решение.

Методот предлага серија чекори во процесот на дизајнирање кој може да се примени во една од алтернативните ориентации наведени во бионичкиот процес на дизајнирање. Заедничките чекори во двете насоки на анализирање се состојат од истите активности, истиот опис и важат за двете насоки. Versos and Coehlo имаат поставено 5 главни цели на процесот на био-инспирација: ефрикасност на комуникацијата, оптимизација на формата (намалување на големината или количината на употребен материјал, стабилност, намален притисок итн.), задоволување на повеќе барања одеднаш - системот да извршува различни задачи или да исполнува неколку функции во исто време,

\footnotetext{
2 Bionics in Engineering-Defining new Goals in Engineering. Education at "Polytehnica" University of Bucharest - Neurohr, R., Dragomirescu, C.
} 
ефикасност на организацијата и иновација за подобрување на фрункционалноста и перформансите.

Во периодот на подготовка и избор на тема за мојата магистерска работа проучував трудови од областа на бионичкиот дизајн. При тоа особено силен впечаток ми оставија можностите на фрракталниот дизајн. Фракталниот дизајн може да се искористи во случаи каде дизајнот се состои од „форма - во фрорма - во форма“. Тоа би значело дека истиот облик на производот се повторува три пати во различни големини. Овој конкретен проблем најсликовито е претставен кај кромидот. Секој следен слој од внатре нанадвор е поголем и поголем, со што со зголемување на бројот на повторувања се зголемува големината и крутоста на целата форма.
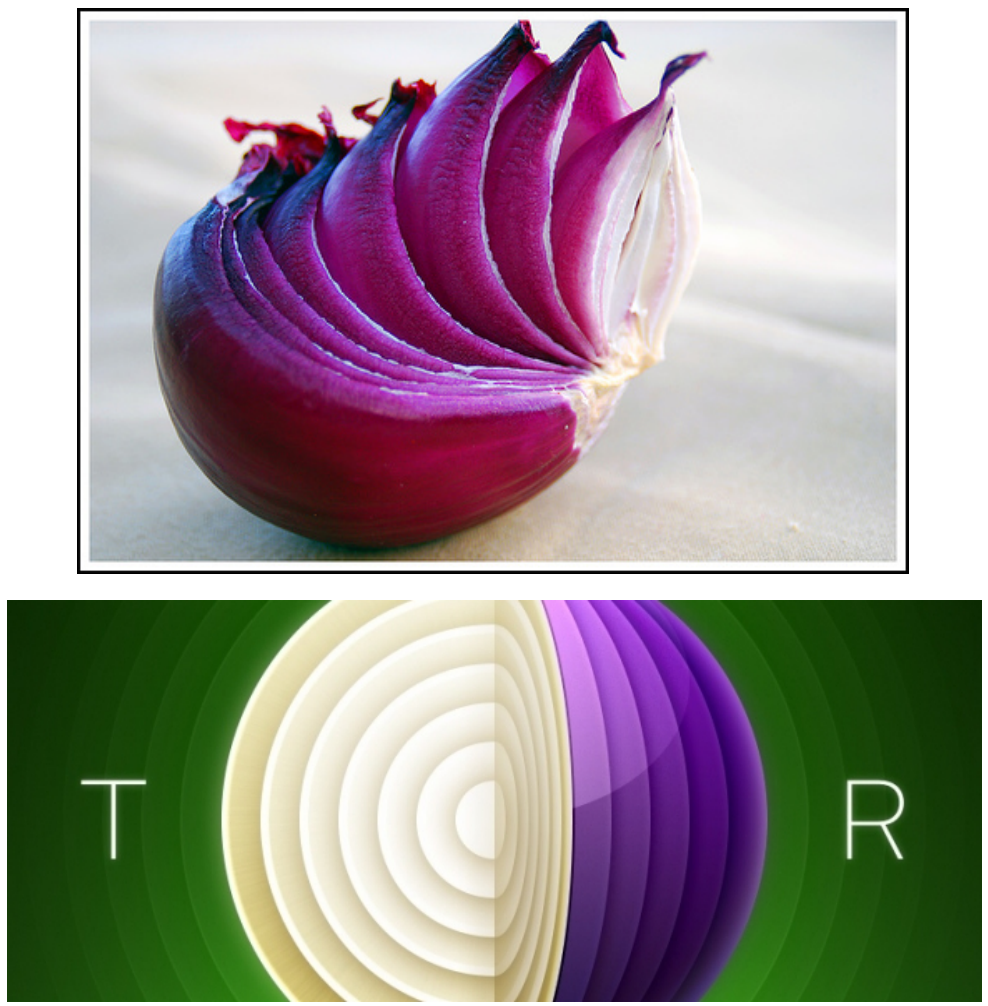

Слики 1 и 2 - Фрактален дизајн на кромидот како урнек за детско седиште

Овој принцип ме наведе на размислување, каде би можел да биде применет во дизајнот на производи. Слоевитата структура асоцира на постепено зголемување на формата на кромидот, што може да биде и реверзибилна операција - додавање и отстранување на слоевите еден по еден.

Со примена на дедуктивниот метод на размислување дојдов до идејата дека овој принцип би бил одлично решение за дизајн на производи каде е 
неопходно прилагодување на големината. По дедуктивен пат барав решенија и одговори на низа последователни прашања:

\begin{tabular}{|l|l|}
\hline \multicolumn{1}{|c|}{ Прашање } & \multicolumn{1}{|c|}{ Одговор } \\
\hline $\begin{array}{l}\text { Кои се тие производи на кои им е } \\
\text { големебно зголемување и намалување на }\end{array}$ & $\begin{array}{l}\text { Производи кои ги користат различни } \\
\text { корисници; } \\
\text { Производи кои ги користат корисници кои } \\
\text { брзо ја менуваат големината на телото. }\end{array}$ \\
\hline $\begin{array}{l}\text { Дали можноста за прилагодување има } \\
\text { економски бенефит? }\end{array}$ & $\begin{array}{l}\text { Производот може да се користи подолго } \\
\text { време и од различни корисници. }\end{array}$ \\
\hline $\begin{array}{l}\text { Кои производи се користат од различни } \\
\text { корисници }\end{array}$ & \begin{tabular}{l} 
Седишта, столчиња, чизми за скијање... \\
\hline $\begin{array}{l}\text { Кои корисници најбрзо ја менуваат } \\
\text { големината на телото? }\end{array}$
\end{tabular} \\
\hline Кои седишта се користат за деца? & $\begin{array}{l}\text { Децата. } \\
\text { велосипедски седишта за превоз на деца, } \\
\text { седишта за столчиња за деца. }\end{array}$ \\
\hline
\end{tabular}

Табела 1 - Клучни прашања и одговори во примена на принципот на модуларност на големината на производите

На овој начин, со примена на бионичкиот пристап оддолу - нагоре, кој започнува со биолошки феномен и се пренесува на потенцијално техничко решение, дојдов до идеја за темата на мојата магистерска работа истражување на ергономскиот проблем прилагодливост на големините на производи наменети за деца. Истовремено одлучив резултатите од ова истражување да ги применам во дизајн на велосипедско седиште за превоз на деца, како најсоодветен пример за експериментално потврдување на сознанијата. Децата брзо растат, па потребно е седиште кое во краток период ќe може да се нагоди во голем опсег на димензии. Со дизајнирање на седиште во кое собира помало седиште, кое содржи во себе уште помало седиште, успешно може да се одговори на барањето за повеќе големини во истиот производ, бидејќи трите седишта би биле интегрирани едно во друго. Со тоа, како што расте детето, би отпаѓала по една форма, се додека детето не достигне 22 кг, или 5-6 години. 


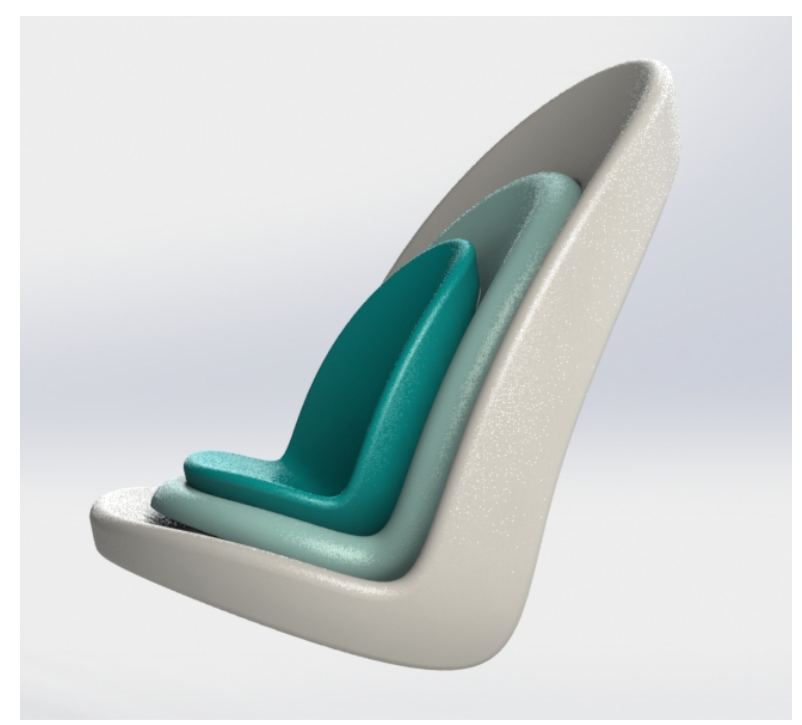

Слика 3 - Сликовит приказ на идејата за примена на решението во конкретен дизајнерски проблем

\section{2 Препораки при дизајнирање за деца}

Речиси сите повреди потекнуваат од незгоди кои би можеле да бидат потенцијално спречени преку подобрен дизајн на производите, просторот, процесите и имплементацијата на едукација за истите преку обуки и програми за надзор. Децата не смеат да се гледаат како возрасни со помал раст. Нивните тела и умови се во фаза на развој, а нивните физички и ментални активности влијаат на нивниот развој. Така, дури и столчињата на кои тие седат можат да влијаат на нивниот раст. Оние кои дизајнираат за деца мора да имаат во предвид каков ефект ќе има нивниот дизајн врз созревањето на детето, што не е случај кога се дизајнираат производи за возрасни. Други важни факти кои треба да се разгледаат се: ${ }^{3}$

○ Децата учат преку проби и грешки, истражување и експерименти;

- Ги користат предметите на неочекувани начини;

○ Покажуваат ризично однесување, често не препознавајќи ја опасноста;

- Не ги разбираат целосно последиците од нивното однесување и

- Не можат точно да ги искажат нивните потреби, желби и неудобности.

Производите наменети за деца треба да се лесни за употреба, но треба да се земе во предвид дека нивниот физички раст брзо се менува, тие немаат искуство во употребата на производи и когнитивниот развој кај децата е

\footnotetext{
${ }^{3}$ Wiley John \& Sons Inc., edit by Salvendy Gavriel, (2012) Handbook of human factors and ergonomic, Fourth edition, Hoboken, New Jersey
} 
нарамномерен. На пример, она што е интуитивно за осум годишно дете може да не е интуитивно за негов врсник кој пораснал во друга околина и услови, со што има различен степен на зрелост.

Родителите очекуваат нивните деца да се вклопат во околината, да се развиваат паралелно со нивните врсници, а понекогаш од производот се очекува само да ги забавува децата. Овие производи со кои децата се во контакт треба да бидат:

○ Безбедни;

○ Да ги поттикнуваат во нивниот развоен напредок;

○ Да им дозволуваат на децата да добијат свесност за околината;

○ Да ги научат важни работи кои ќе им бидат потребни во иднина;

○ Да бидат во согласност со верувањата и вредностите на родителите;

○ Треба да ги развеселат и да им го задржат вниманието.

\section{3 Ергономски истражувања за прилагодување на големините}

\section{на производите во зависност од големината на}

\section{корисниците}

Потребата седиштето да биде дизајнирано со цел да може да се прилагоди во зависност од големината на корисникот значи и сосема поинаков тек на развојот на еден нов производ, особено ако неговата таргет група се децата.

Gregory Jerom Usher ${ }^{4}$ е пронаоѓачот на детско балансирачко столче, прикажано на слика 4. Неговиот патентиран дизајн, претставува интересно истражување од оваа област. Тој го замислил механизмот во вид на метална конструкција со телескопски цевки кои влегуваат една во друга. Како што расте детето, седиштето се поткрева на погорните држачи, и се прицврстува со завртки, додека другите држачи можат комплетно да се отстранат. Седиштето на ова столче може да се поместува и напред - назад, како и да се менува аголот на наклон на потпирачот. Тоа го прави производот корисен: а) за време на развојот на детето, кога тоа континуирано расте; и б) при помагање на навалувањето нанапред и наназад на телото, со што се намалува

\footnotetext{
${ }^{4}$ Jerom Usher, Gregory: (1997) Child's balance seat, US patent, Australia
} 
оптоварувањето на р'бетниот столб, а се префрла на потколениците, кои се наслонети на перничиња.

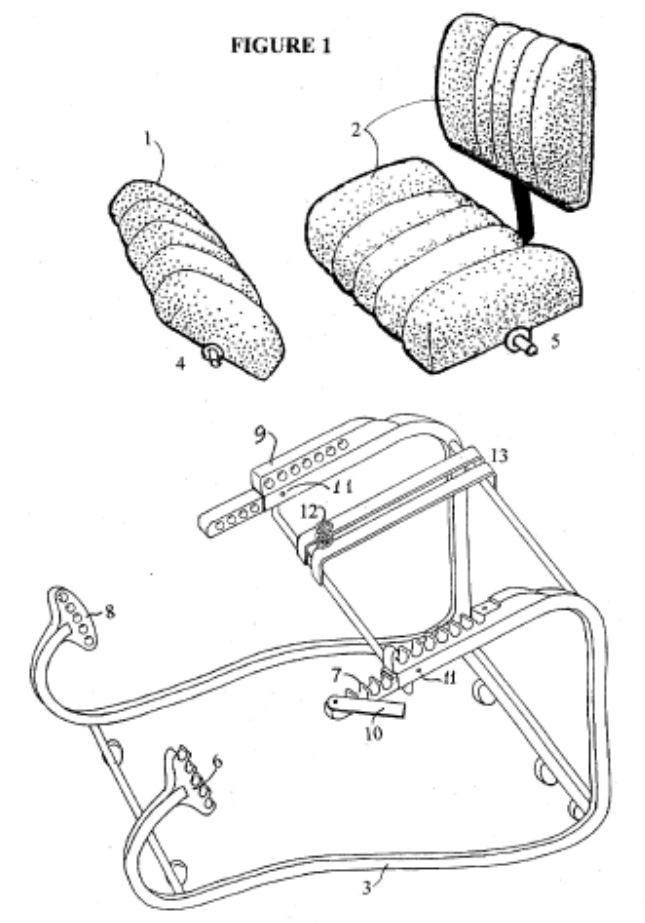

Слика 4 - Детско балансирачко столче

Betina Lindbloom 5 има сосема друг пристап во прилагодувањето на големината на производите. Нејзиниот придонес на ова поле се состои во понудата на голем број различни начини на зголемување на носечкиот простор кај кенгурите за носење на бебиња. Под носечки простор овде се подразбира делот кој го држи р'бетот на бебето исправен и припиен до телото на оној кој го носи. Идејата е со користење на постоечките елементи: патенти, велкро ленти, врвки, полимерни шноли, стеги, ремени и нивна комбинација да постигне полесно нагодување на големината на кенгурот како што детето расте, почнувајќи од најмали бебиња, па се до 4 годишни деца. Овој изум не мора да се ограничи само на понудените решенија, туку и на оние кои би произлегле од нив со истиот начин на размислување - на пр. лентите можат да бидат поврзани со ремен, меѓусебно зашиени, врзани или протнати низ шнола.

\footnotetext{
${ }^{5}$ Lindbloom Betina (2014) Arrangement for adjusting the length of a carrying section of a child carrier, BabyIdea OY, Helsinki, Finland
} 
Крајниот производ овозможува детето да може да се носи на повеќе начини: со лицето кон носителот, завртено нанадвор, на рамена на носителот (како ранец), или странично на едниот колк.
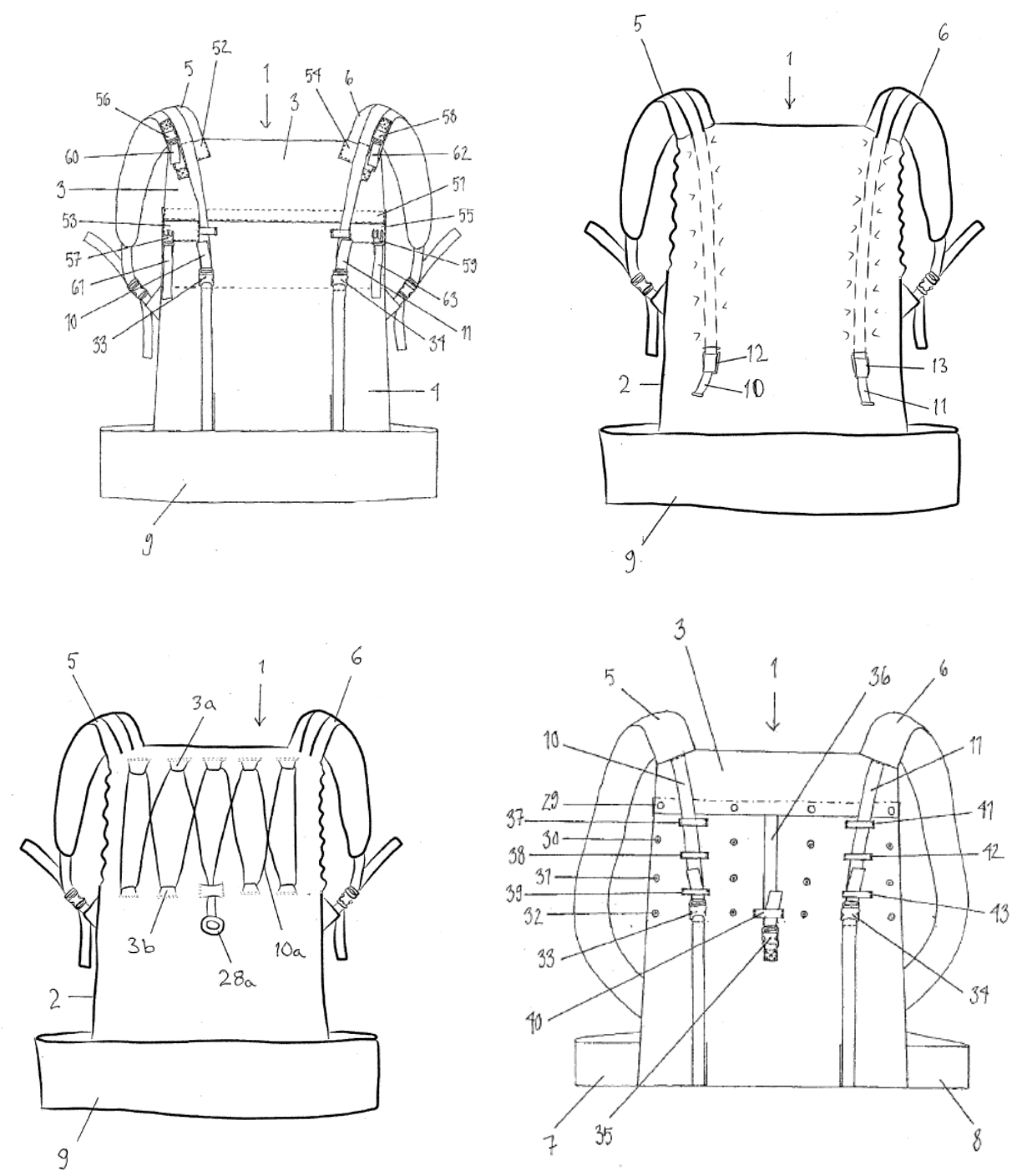

Слика 5 - Неколку варијанти на прилагодување на големината на кенгур за носење на деца од различни возрасти

Позитивната страна на детското балансирано столче е подобрено држење на телото и флексибилност - прилагодливост за голем опсег на различни возрасти на деца, додека негативни страни се тешката и габаритна конструкција, како и потребата од рачен алат за да се нагоди до посакуваната големина.

Вториот случај со прилагодувањето на големината со помош на готови модули, како патенти, велкро ленти, врвки, полимерни шноли, стеги, ремени и 
нивна комбинација е многу попрактичен, и може да биде добра инспирација за мојот дизајнерски проблем, притоа овозможува мала маса, што е особено важно кога на себе ја имате и тежината на детето. Сметам дека е од голема важност да проучиме како други дузајнери решиле сличен проблем на барањето кое е поставено пред нас.

\section{4 Нови ергономски материјали}

Кога станува збор за дизајн на производи не можеме да го занемариме значењето на материјалите. Постојано се појавуваат нови материјали и технологии за нивна обработка, кои нудат подобар квалитет на производите, подобра естетика, подобра ергономија, а стануваат и инспирација за нови трендови во дизајнот. Во продолжение направив преглед на неколку нови материјали кои можат да послужат како добра инспирација за понатамошниот процес на дизајнирање.

Пенестите гуми ${ }^{6}$ користат агенс за надувување, кој создава мали меурчиња во течната смеса. Типично, оваа смеса содржи полиоли, полизоцијанати, вода и адитиви. Постојат многу различни агенси, а пенењето се користи за екструзија и бризгање на гумите.

Полиолите и полизоцијанатите се течни полимери кои, комбинирани со вода, произведуваат егзотермичка реакција која дава топлина. Со комбинација на специфични типови од овие течни полимери, се добиваат крути или еластични гуми. За време на полимеризацијата, пенењето може да се контролира со менување на количеството вода или сурфактанти.
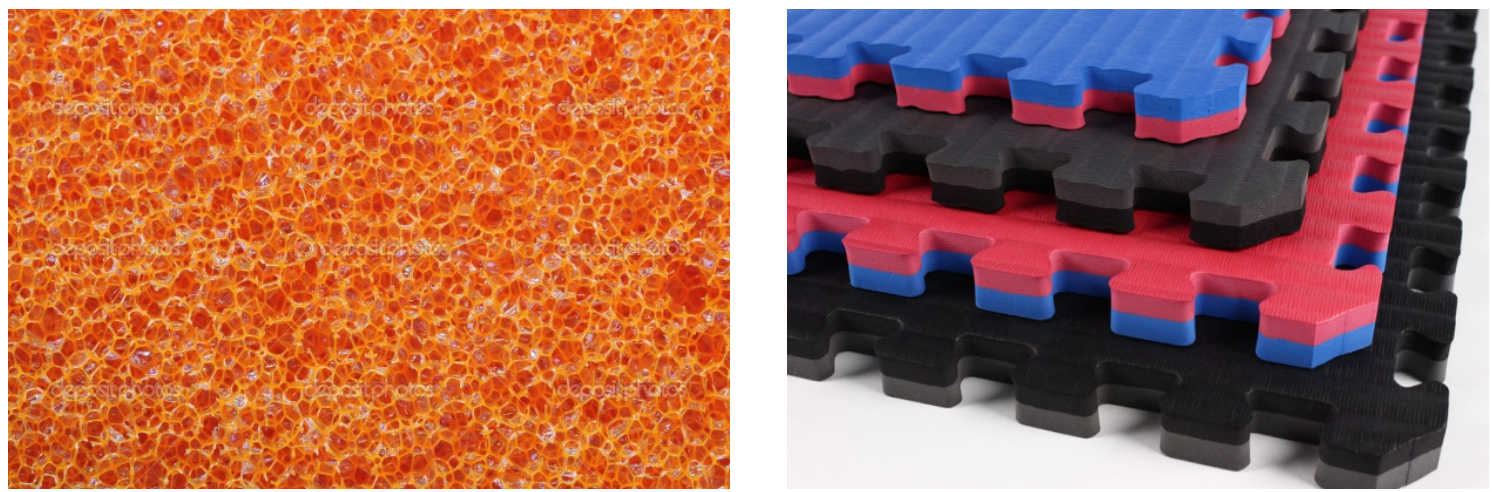

Слики 6 и 7- Микроскопска структура и примена на пенестите гуми

\footnotetext{
${ }^{6}$ Извор: http://www.elastoproxy.com/en/blog/foam-rubber-vs-sponge-rubber-whats-difference/
} 
Сунѓерестите гуми доаѓаат во два вида: со отворени и затворени ќелии. Гумите со отворени ќелии имаат отворени, меѓусебно поврзани џебови кои дозволуваат проток на воздух, вода и други хемикалии кога материјалот не е компресиран. Другите гуми имаат затворени ќелии како балончиња кои се полни со азот, и со тоа спречуваат проток на воздух и вода при ниски притисоци.

За да се произведе сунѓереста гума со отворени ќелии, натриум бикарбонат се додава на другите состојки во загреан алат. Како што сунѓерестата гума нараснува како тесто со квасец, сода бикарбоната создава отворени, поврзани ќелии. За да се направи гума со затворени ќелии, се додава хемиски прашок кој се разложува под дејство на топлина и притисок. Азотот кој се ослободува притоа, придонесува за одличните карактеристики на враќање во првобитната состојба на оваа гума, како и степенот на компресија.

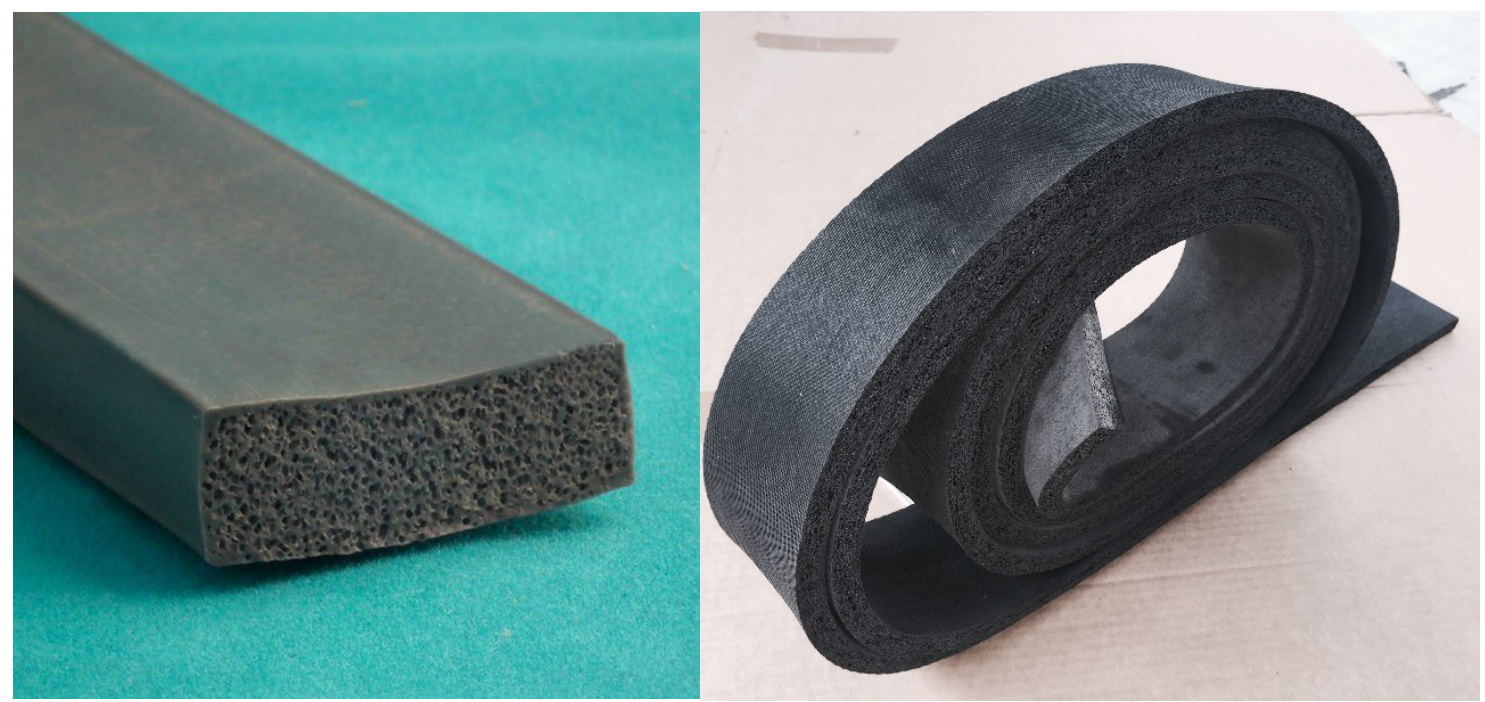

Слики 8 и 9 - Сунѓерести гуми со отворени и затворени ќелии

Иако азотот е гас, тој не произведува пена како агенсите за пенење кои се користат кај пенестите гуми. Пенењето е специфичен процес, а пенестите гуми се најчесто со отворени ќелии. Иако некои нивни ќелии се затворени, сепак овие гумени полимери не можат да го положат ASTM, тестот за апсорпција на вода, кој е стандардно барање во индустријата на материјали со затворени ќелии. 


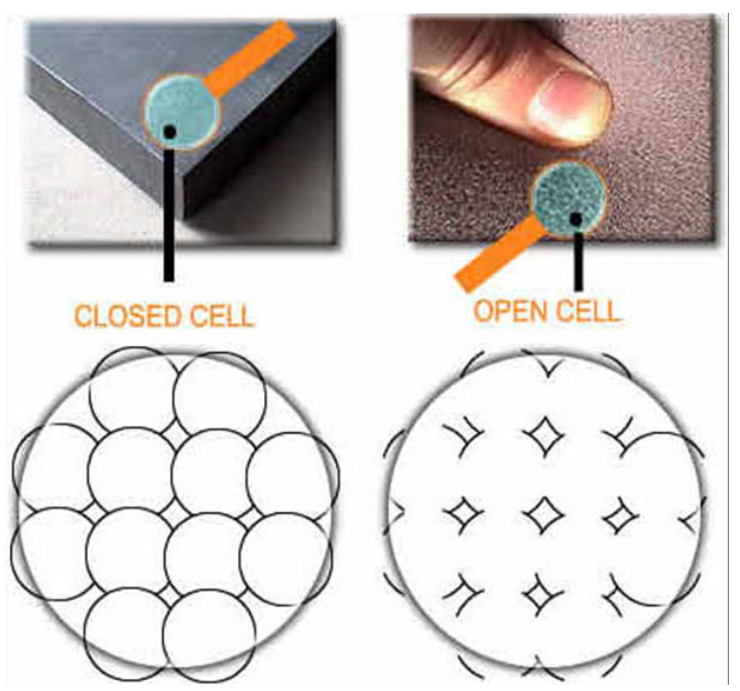

Слика 10- Споредба меѓу типовите сунѓерести гуми

Сунѓерестите гуми со затворени ќелии имаат широк дијапазон на примена ${ }^{7}$, заради отпорноста на стареење и атмосферски влијанија, одличната температурна стабилност и водоотпорноста, и тоа во автомобилска индустрија, кај радијаторските, градинарските и други црева, кај електричните изолации, мембрани на покривите, и примени кај системи изложени на озонот.

Пенестите гуми имаат уште поширока примена, заради отпорноста на УВ зраците, атмосферските влијанија, оксидација, габи, скоро сите растворувачи и хемикалии и можноста да се лепат со адхезиви кои се осетливи на притисок. Се користат кај седиштата за автомобили и мебелот, ѓонови на спортски обувки и изолација кај фррижидери, згради и транспортни возила.

Меѓу другите материјали кои ги истражував, во контекст на дизајнот на детско седиште, вредат да се споменат мешавините од природна и полимерна гума, како: Neoprene/EPDM/SBR, која е одлична за придушување вибрации и амортизација и отпорна на атмосферски влијанија, силиконската гума, како изолатор во машинството, градежништвото, производната индустрија и гумата co заштитен состав Viton®, со екстремни перформанси, применета во вселенските летала.

Се разбира дека компатибилноста на овие материјали со детско седиште лежи само во својствата, не и во исплатливоста, бидејќи тие чинат многу за да може било кој производител да си дозволи да ги примени во седиште за велосипед.

\footnotetext{
${ }^{7}$ Извор: http://www.igmarston.com/rubber-product-materials.html
} 


\section{5 Неколку примери на подобрување на ергономскиот дизајн}

\section{на производите со употреба на нови материјали}

\subsubsection{EVA полимер}

Кога на дизајн студиото од Токио, h220430"8, му доделиле задача да дизајнира столче за во јапонските детски градинки, директорот се изјаснил дека сака парче мебел кое бара интеракција од корисниците. Се покажало дека најдобриот начин да се стимулира детската креативност е да им се дозволи на малечките да учествуваат во целогодишниот дизајн процес. Биле подготвени неколку прототипи од кои се одбирал најдобриот според следните критериуми: леснотија на склопување, продуктивност, ергономија и дизајн.

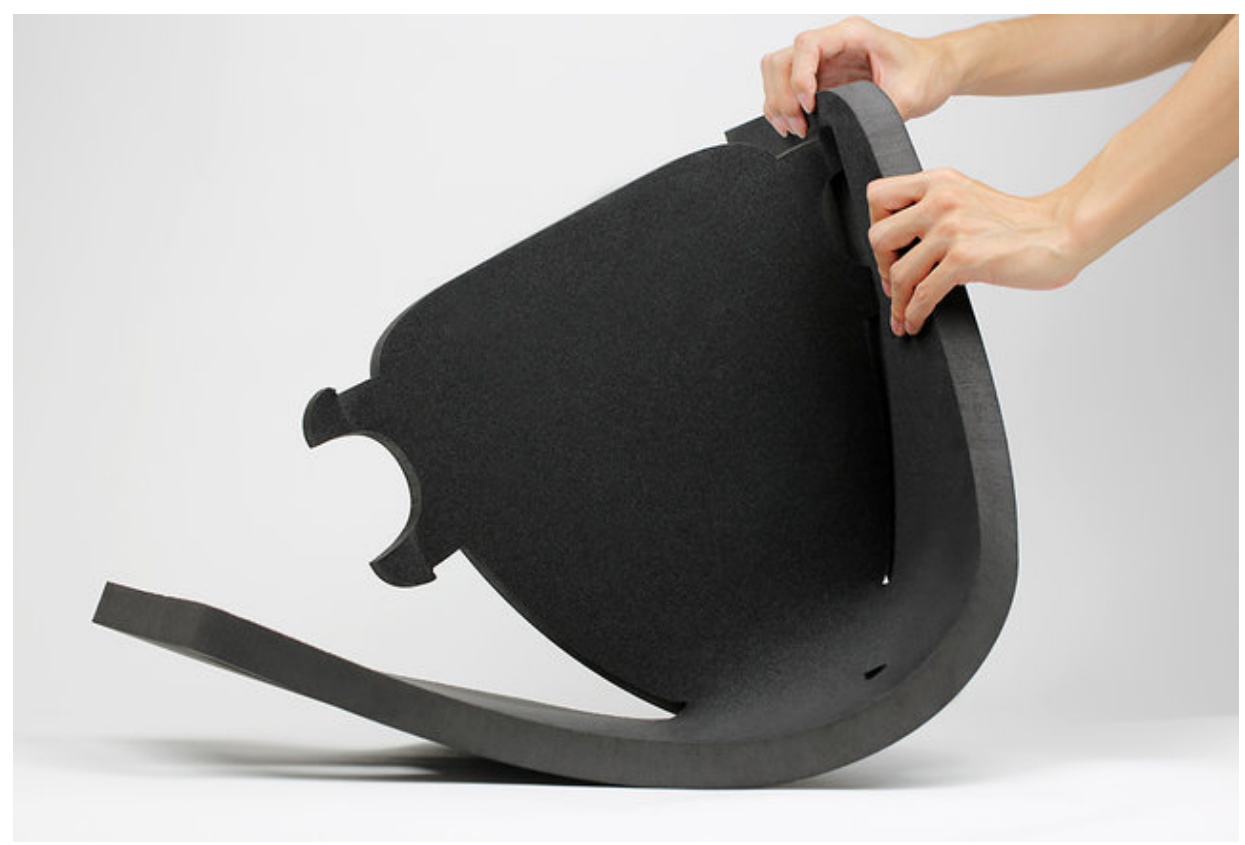

Слика 11- Owl Chair во фаза на склопување

EVA (етилен- винил ацетат) полимерот ги обезбедил идеалните својства како материјал за овој дизајн - меката и флексибилна полимерна пена се однесува како гума, што ја прави лесна за манипулација. Инаку, на ова студио не му било првпат да експериментира со матрилјаот EVA во дизајн на производи за мали дечиња од предшколска возраст. Столчето го добило името според неговата форма, која кога ќе се постави на подот во развиена фрорма, личи на був со раширени крила.

\footnotetext{
${ }^{8}$ Извор: http://www.fastcodesign.com/1671543/an-ingenious-kids-seat-that-encourages-interaction/2
} 


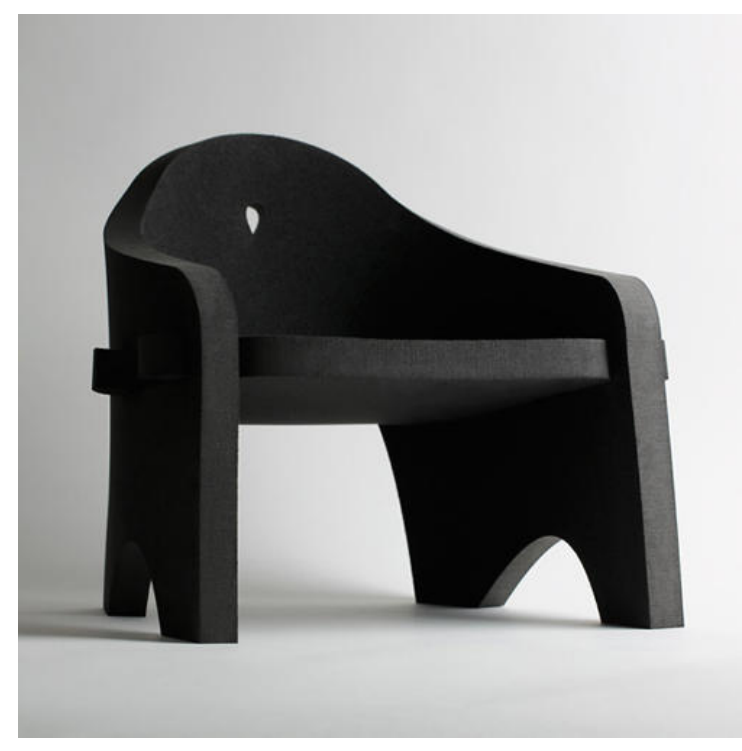

Слика 12 - Owl Chair во конечна фраза

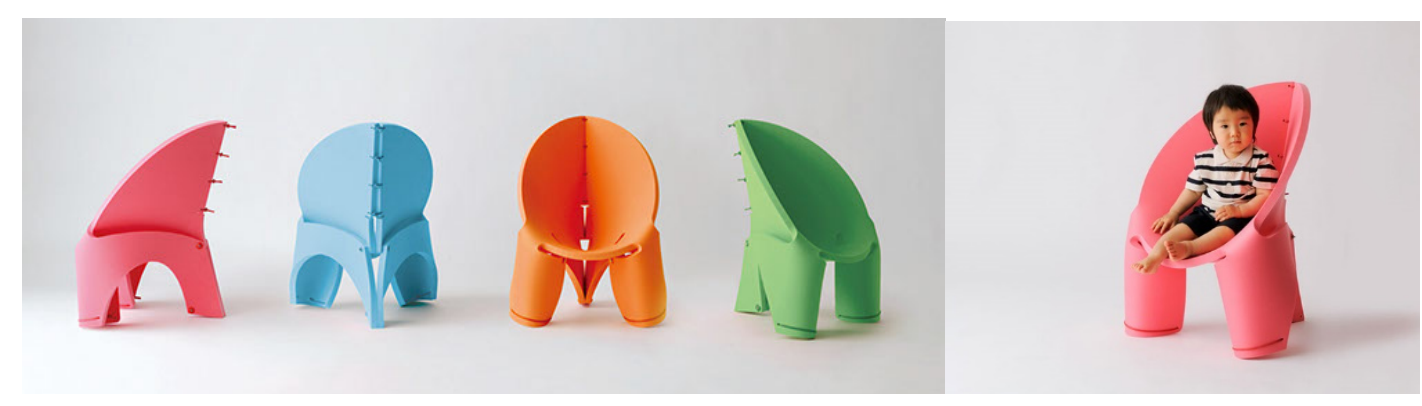

Слика 13 в- Други детски столчиња од истото дизајн студио

\subsubsection{DuPont ${ }^{\mathrm{TM}}$ HytreI® TPC-ET и Crastin® PBT}

Канцелариското столче the Generation на Knoll®, дизајнирано од Formway Design од Нов Зеланд, нуди сосема нова палета на удобност и неограничено движење, со обезбедување повеќе пози и работни стилови кои се типични за денешните динамични работни места. The Generation chair ${ }^{9}$ ce потпира на идејата за еластичен дизајн, каде производот се прилагодува на положбата на корисникот.

Користејќи ги специјалните фрлексибилни својства на DuPont термопластиките со високи перформанси, столчето буквално се свиткува како што корисникот ја менува позицијата, одговарајќи на неговите движења. Клучот на успехот за наградениот дизајн се должи на користењето на материјалите онака како што досега не биле искористени во индустријата за мебел. Флексибилната термопластика зазема значителен број на функционални и

\footnotetext{
${ }^{9}$ Извор: http://www.dupont.com/products-and-services/plastics-polymers-resins/thermoplastics/casestudies/flexible-plastic-in-seating.html
} 
структурални компоненти од столчето, како потпирачот за грб (Flex Back) и контролата на динамичката амортизација (Dynamic Suspension Control), кои се изработени од заштитениот материјал на DuPont ${ }^{\mathrm{TM}}$, Hytrel® TPC-ET и Crastin® PBT.
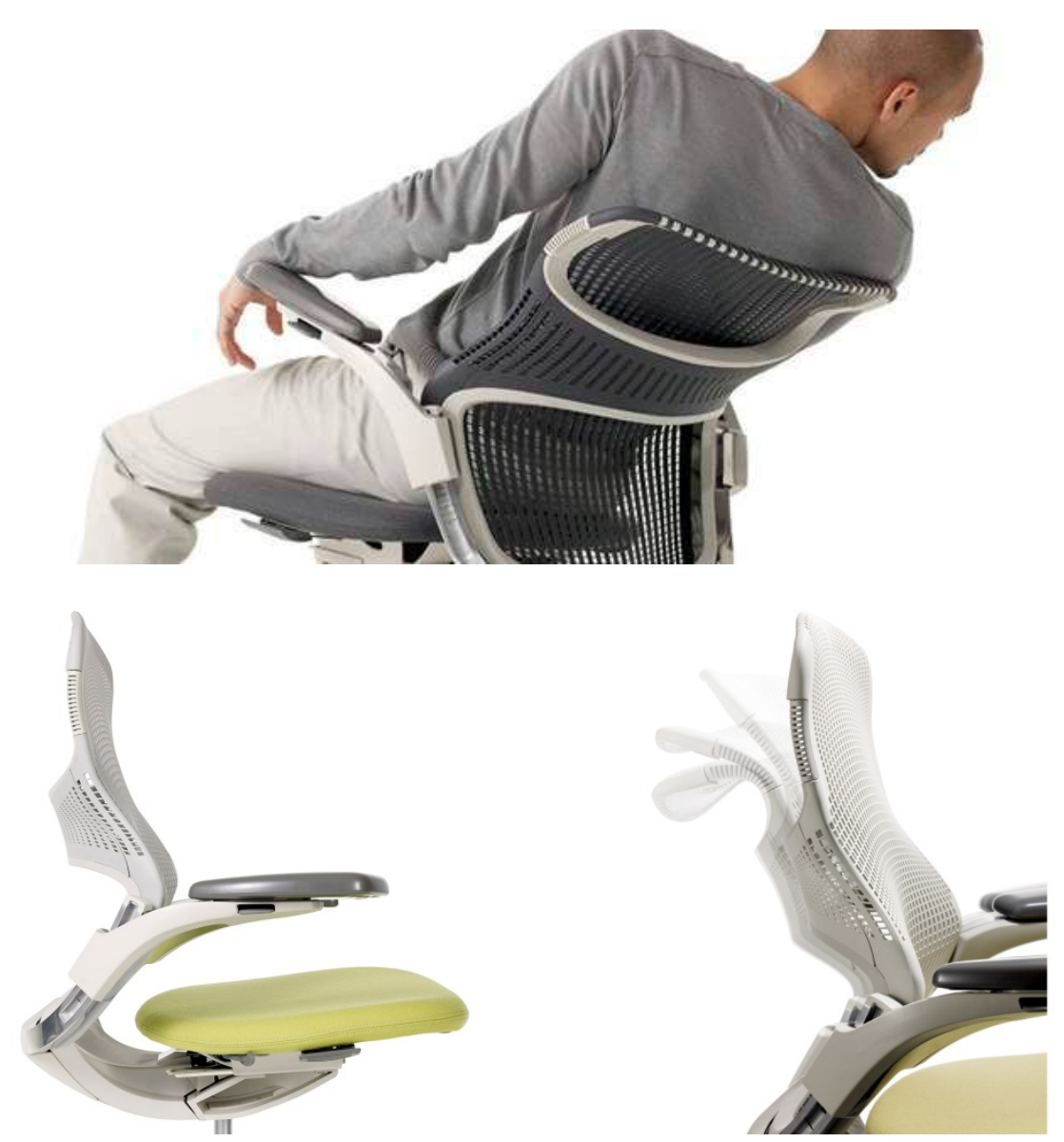

Слика 14 - Generation Chair на Knoll

Дизајнот Flex Back е потпирач без рамка, со мрежа која личи на осумка вклопена во фрормата. Би било погрешно овие две компоненти да ги идентификуваме како скелет и кожа, бидејќи тие се испреплетени - вели Benjamin Pardo, дизајн директорот на Knoll. Иновативната контрола на динамичката амортизација (Dynamic Suspension Control) е едноставна, немеханичка контрола која овозможува мазно поместување, со компензација на тежината. Без комплицираните метални конструкции или пружини, оваа конструкција користи третина од бројот на делови вообичани кај традиционалните механизми за столчиња. Својствата на материјалот, 
издржливост и фрлексибилност, овозможуваат енергизирачко, повеќенасочно движење кое ги спојува формата и функцијата.

Мрежата Flex Back е направена од Hytrel® RS, материјал кој содржи барем 50\% обновливи состојки по единица маса. Тој креира помалку отпад штетен по околината од сите петрохемиски-базирани материјали кои ги заменува, без компромис во перформансите.

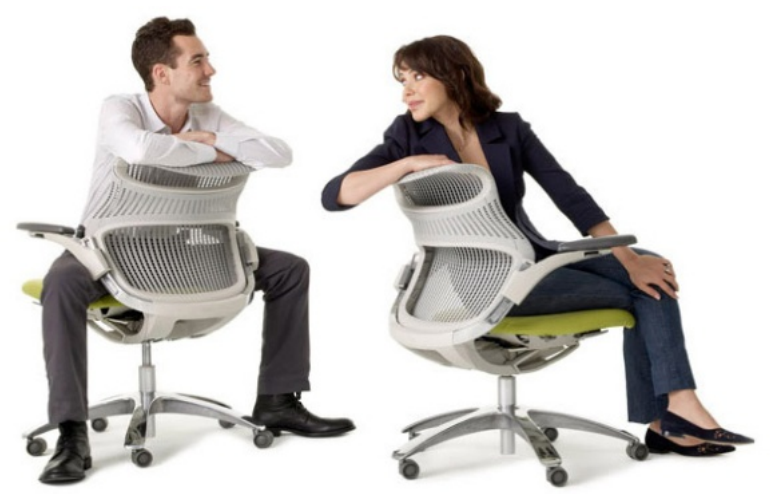

Слика 15 - Generation Chair во реална примена

\section{6 Заклучок од истражувањето}

Претходните истражувања од биониката ми овозможија да дојдам до конкретната тема на мојата магистерска работа. Фракталите во природата и урнекот со слоевитата градба на кромидот ми дадоа идеја да се обидам да предложам иновативен пристап во решавањето на ергономскиот проблем прилагодување на големините кај производите. Со дедуктивен метод дојдов до идеја каде да се примени овој пристап со цел да биде соодветно проверен и презентиран. Имено, велосипедското седиште за превоз на деца е сосема адекватен пример за неопходноста од адаптација на големината со цел да се овозможи што подолга примена.

Ергономските истражувања ми ги помогнаа во откривањето на суштинските принципи и методи за дефинирање на димензиите, но и на големините на производот, како и на обезбедување на удобноста и безбедноста на истиот.

Од природата на дизајнот на детското седиште за велосипед, очигледно е дека материјалот има круцијално значење во успешноста на производот. Истражувањето на новите материјали ми помогна да се насочам кон потрага по 
нови дизајнерски решенија за постоечки производи. Сметам дека извонредните карактеристики на EVA полимерот се многу инспиративни и дека ми овозможија иновативен пристап во решавањето на конкретниот дизајнерски проблем. Материјалите од кои е изработено фрлексибилното столче Generation Chair имаат навистина фрасцинантни својства, но сепак се помалку соодветни за детско седиште, бидеќ децата тешко седат мирни, па би било опасно на велосипед, во сообраќај самото седиште да ја менува својата форма.

Може да се заклучи дека идеалниот материјал за овој вид производ, во овој случај EVA полимерот, ги обезбедува најдобрите својства од пенестите и сунѓерестите гуми, разгледани во ова поглавје: отпорноста на УВ зраците, атмосферските влијанија, оксидација, габи, одличната температурна стабилност, отпорност на стареење и водоотпорност. 


\section{3 Анализа на пазарот - постоечки велосипедски седишта за превоз на деца}

Во последно време сѐ поголем тренд станува еко дизајнот, масовното производство по мерка, како и намалувањето на штетното влијание врз животната средина. Поради тоа, сѐ повеќе се става акцент на велосипедот како превозно средство кое не испушта издувни гасови, а влијае добро и на здравјето и општата спортска кондиција, бидејќи како „гориво“ ги користи масните наслаги на човекот. Во овој контекст посебно ранлива група се децата, а нивната безбедност на велосипед, како во сообраќајот, така и во природа е најважна за секој родител. Оттука се јавува и потребата за квалитетно детско седиште за велосипед во кое тие би имале доверба од аспект на безбедност, ергономија, употребените материјали, итн. Од овие аспекти произлегуваат и критериумите кои имаат одлучувачко значење при компарацијата на различните алтернативи, како дел од анализата на постоечките седишта на пазарот.

\section{1 Основни видови на детски седишта}

Во ова поглавје се разгледани основните поделби на детските седишта за велосипед, поделени според местоположбата на поставување на велосипедот.

\subsection{1 Задни детски седишта}

Задните седишта понатаму ќе бидат обележани со латиничната буква A. Можат да се најдат во три основни дизајни:

I А - Конзолни - поврзани директно со цевката на седиштето на возачот;

II А - Фиксирани на багажникот на велосипедот;

III А - Конзолни - поврзани со рамот на велосипедот.

\subsection{2 Предни детски седишта}

Предните седишта се обележани со латиничната буква В. И тие, исто како и задните, се произведуваат во три основни дизајни:

I В - Фиксирани за конструкција за горниот дел од рамот;

II В - Фиксирани директно на горниот дел од рамот;

III В - Фиксирани директно на стемот од велосипедот. 


\section{2 Предности и недостатоци на основните видови седишта}

Самото возење на велосипед заедно со детето носи низа предности, како што се здравите навики за движење, учење на децата од најмала возраст за заштитата на животната средина, поминување на повеќе време заедно и зближување со децата преку рекреативни активности.

Добрите страни на предните седишта вклучуваат слобода на детето да разгледува наоколу и да има чувство дека е вклучено во управувањето на велосипедот, помала маса и поедноставна монтажа. Задните седишта, од друга страна се компатибилни со повеќе видови велосипеди, имаат поголема искористливост а со тоа се и поисплатлива инвестиција.

Според мислењата на потрошувачите ${ }^{10}$, како општ главен недостаток на предните детски седишта е намалената контрола при возење поради тоа што возачот треба да се напрега за да може да гледа пред него. Поради тоа, повеќето предни седишта најчесто се за деца помали од 2 години, кои се доволно ниски за да може возењето да се одвива непречено.

Од друга страна, задните седишта имаат друг недостаток - возачот мора да вози во неприродна положба бидејќи не може да ги движи нозете кружно како што тоа го бараат педалите, поради колената на детето кое се вози позади. Друг проблем е додатната тежина од детето која треба да се совлада, бидејќи задните седишта најчесто се наменети за постари деца, до 5-6 години, или до 22 кг.

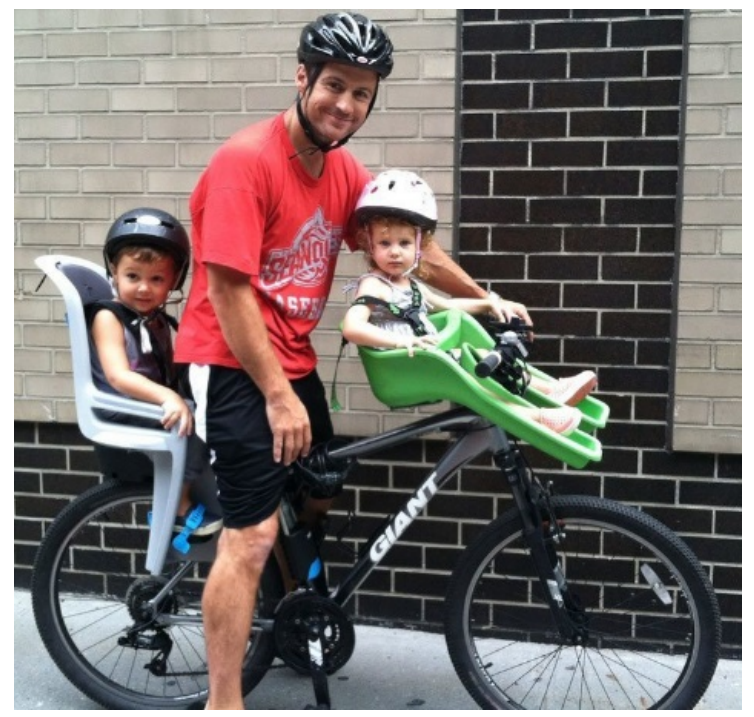

Слика 1 - Предно и задно седиште монтирани на истиот велосипед

\footnotetext{
${ }^{10}$ Извор: http://www.twowheelingtots.com/child-bike-seat-comparison-guide/
} 


\section{3 Преглед на најпопуларните велосипедски седишта за}

\section{превоз на деца}

За потребите на овој труд разгледав осум различни алтернативни концепти кои котираа највисоко на пазарот на детски седишта за 2016 година. Повеќето се димензионирани за деца од 9 месеци до 5 години, или до 22 кг. Направена е и визуелна компарација меѓу нив според шест различни критериуми, од кои некои се технички спецификации, а некои променливи кои зависат од пазарот и мислењето на купувачите.

\subsubsection{Hamax Cares}

Ова седиште е едно од најдобрите од брендот Hamax. Се одликува со лесна монтажа, променлив агол на наклон и променлива висина на потпирачите за грб и нозе. Има и вграден систем за заклучување на велосипедот, за заштита од кражби и фрлуорецентен дел од задната страна за подобра видливост навечер. Овој модел е во исто време од тип IA и IIIA, со тоа што може да се монтира на цевката од седиштето на возачот, и на долниот дел од рамот, во зависност од адаптерот кој е искористен.

Негативната страна кај ова седиште е тоа што појасот е тежок за отклучување, што дополнително го зголемува времето за ракување ако се земе во предвид дека е наменет за мали деца.
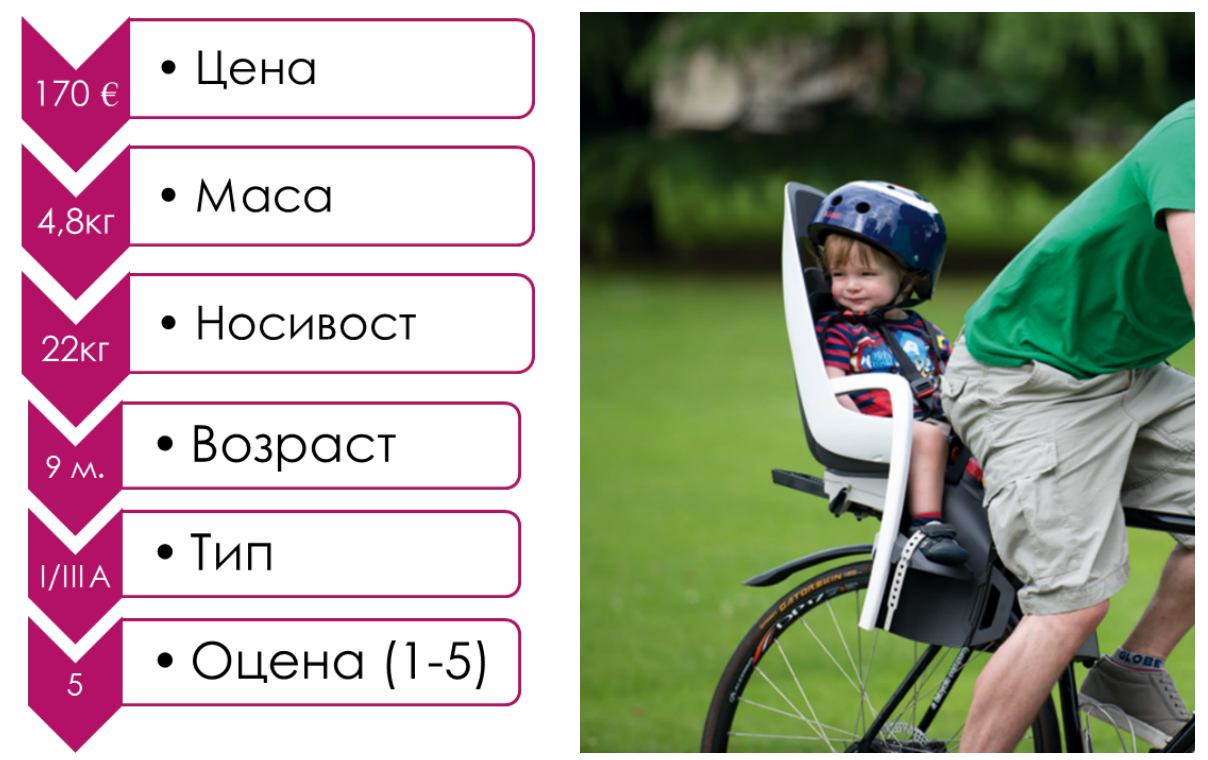

Слика 2 - Спецификации и реална примена на Hamax Cares 


\subsubsection{OK Baby 10+}

Моделот 10+ на италијанскиот бренд OK Baby е оценет како дизајн кој е лесен за поставување и расклопување, а воедно и интуитивен, бидејќи не одзема многу време за да се идентификуваат компонентите. Аголот на наклон е променлив кај потпирачот за грб, а се менуваат и висините на потпирачите за грб и нозе. Седиштето се одликува со добра амортизација и систем за заклучување.

Негативна страна е намалената безбедност, затоа што за разлика од претходното седиште, има многу поголема отворена површина, а со тоа и опасност од удар, особено при возењето во градскиот сообраќај.
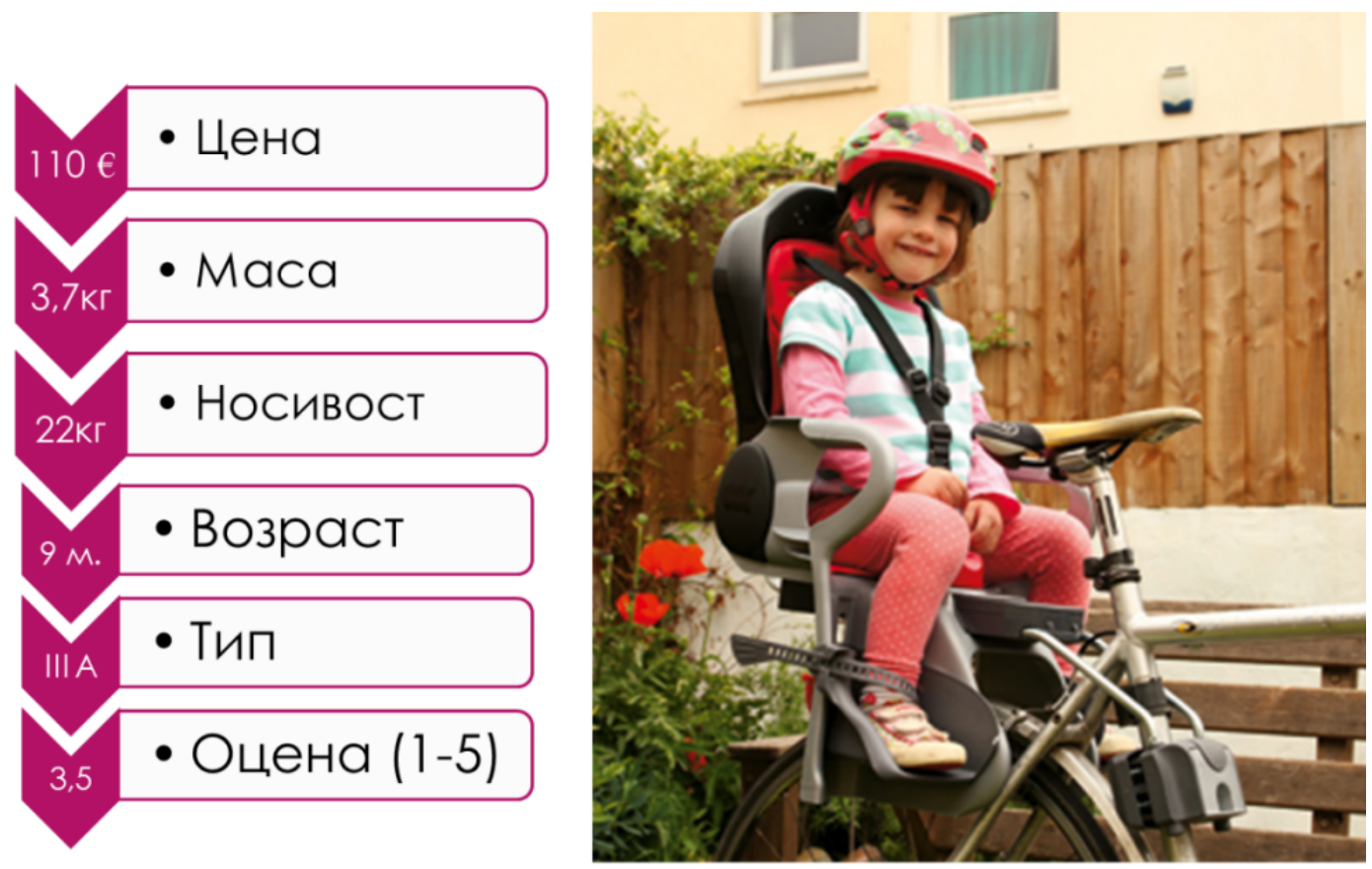

Слика 3- Спецификации и реална примена на OK Baby 10+ 


\subsubsection{Bobike Maxi Tour}

Холандија сама по себе асоцира на велосипедизам, па нема потреба да се дискутира инволвираноста на холандските дизајнери во оваа индустрија. Самото седиште се смета за побезбедно од повеќето модели, заради заштитата за главата, има променлив агол на наклон и висина на нозете за деца од различни возрасти, и вградено ЛЕД светло.

Сепак, негативните страни на кои родителите обрнале внимание се: комплицирано за монтажа, неинтуитивен дизајн и тешко закопчување на појасот. Во продолжение се прикажани оцените, спецификациите и цената на производот.
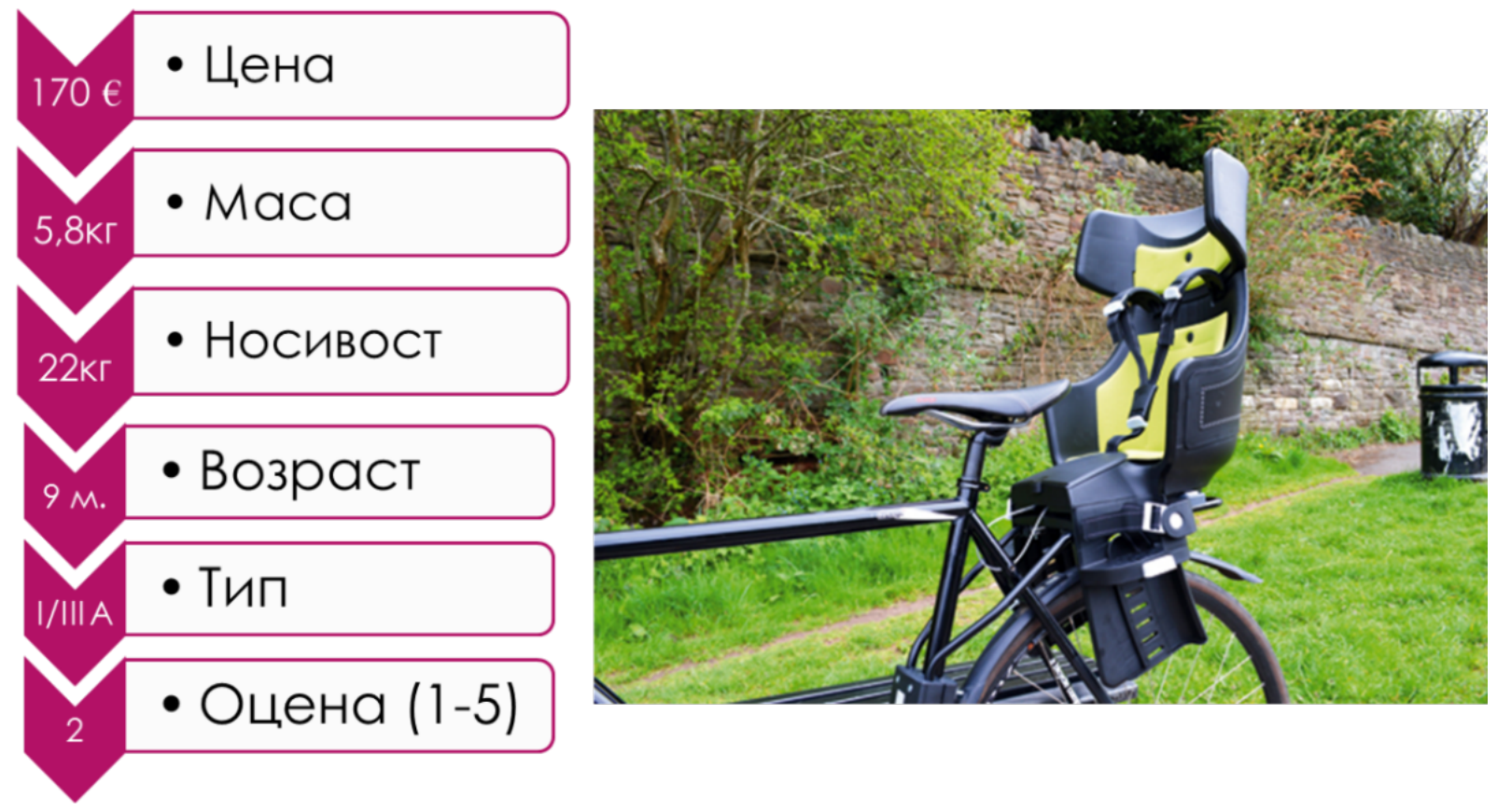

Слика 4 - Спецификации и реална примена на Bobike Maxi Tour 


\subsubsection{Hamax Kiss}

Другата варијанта на седиште од овој производител не е толку квалитетна како првата, но дефинитивно повеќе се исплати за цената. Лесната монтажа, променливиот агол на наклон, променливите висини за потпирачите за грб и нозе и системот за заклучување го прават конкуретно на пазарот во споредба со другите понудени алтернативи. Ова седиште од страна на купувачите се смета за стабилно и безбедно, освен што појасот тешко се откопчува со една рака, што го отежнува качувањето и симнувањето, бидејќи треба седиштето со детето во него да се држи на велосипедот со другата рака.
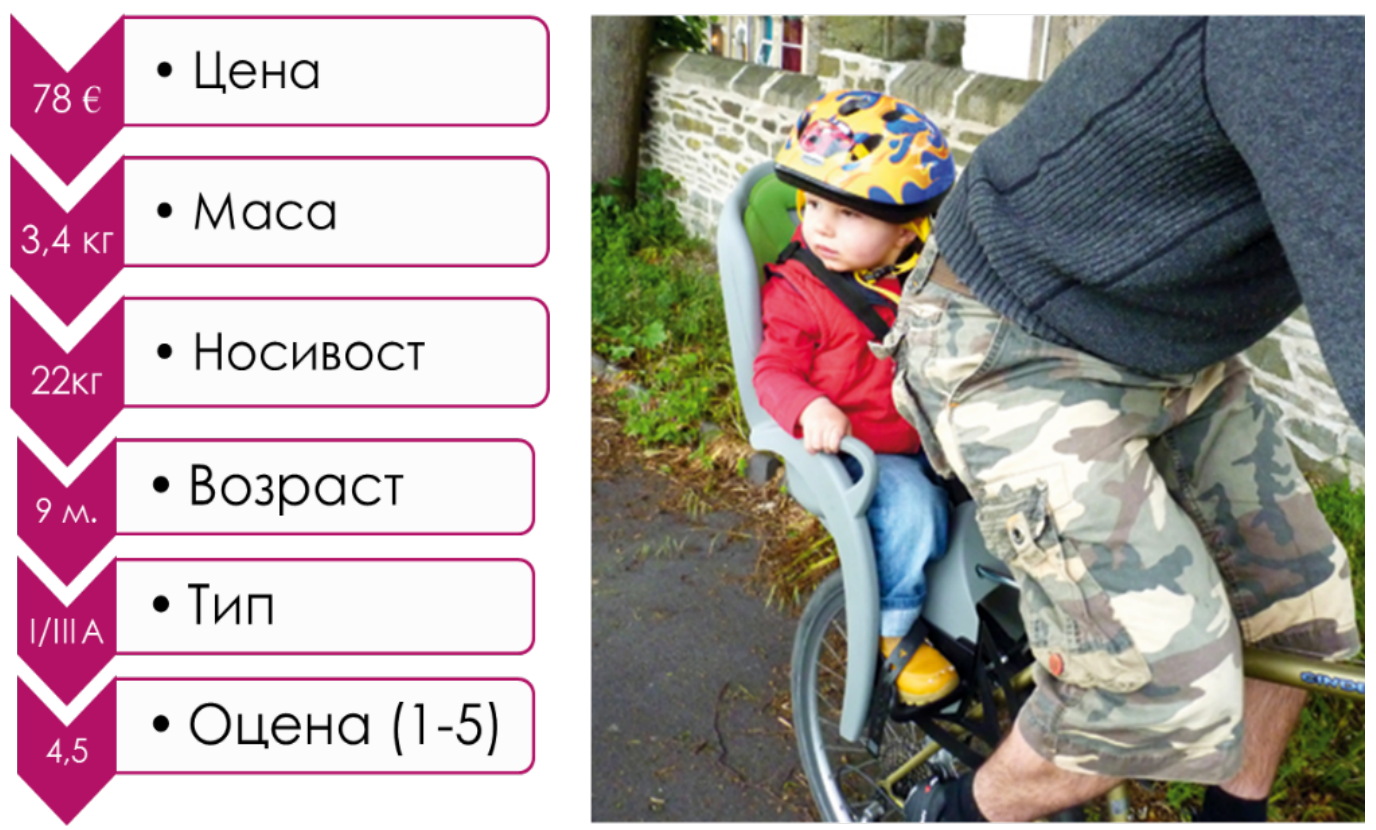

Слика 5 - Спецификации и реална примена на Hamax Kiss 


\subsubsection{WeeRide Classic}

Ова седиште се разликува од останатите наведени претходно поради воланот кој служи за да може детето да се потпира, бидејќи тоа е предно поставено на специјална конструкција над горниот дел од рамот. Позитивната страна се состои во тоа што детето има многу подобар поглед за време на возењето и чувство дека учествува во управувањето. Како и кај другите модели, WeeRide Classic има систем за заклучување и променлива висина на потпирачите за грб и нозе.

Негативните страни се состојат во комплицираната монтажа и сигурносниот појас, кој не е доволно подеслив за различни возрасти на деца и недоволно безбеден бидејќи може да се отклучи за време на возењето.
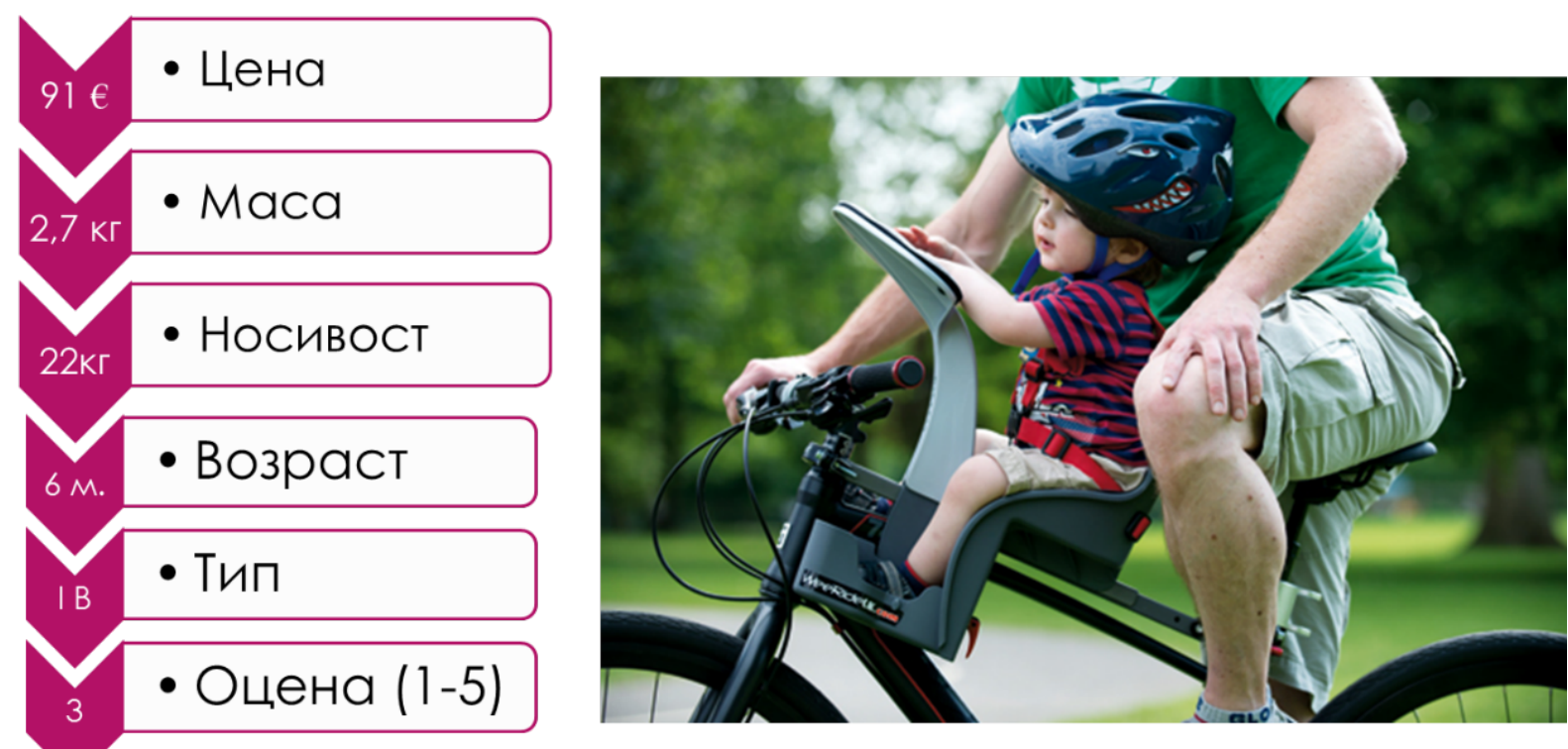

Слика 6 - Спецификации и реална примена на WeeRide Classic 


\subsubsection{Yepp mini}

Ова седиште е едно од моите омилени модели, бидејќи спојува повеќе позитивни особини во атрактивен и едноставен дизајн. Материјалот е EVA полимер, материјал сличен на гума кој е поставен околу тенка челична рамка која го врамува седиштето. Оваа комбинација на полимер и челик дава мекост и амортизација на седењето без да се жртвува издржливоста и трајноста. Се поставува на стемови од велосипедот со дијаметар од 0,8 до 1,1 инч.

Самиот иновативен полимер е водоотпорен, не апсорбира топлина, што е многу важно за возење на високи летни температури и е лесен за чистење. Други одлики се: лесна монтажа, преден потпирач со додатно опционално перниче во случај ако детето заспие, мала маса и систем за заклучување. Има добиено и неколку награди за детски дизајн.

Негативните страни се: тешко качување и симнување, помала безбедност бидејќи седиштето е поотворено и потешко управување со воланот.
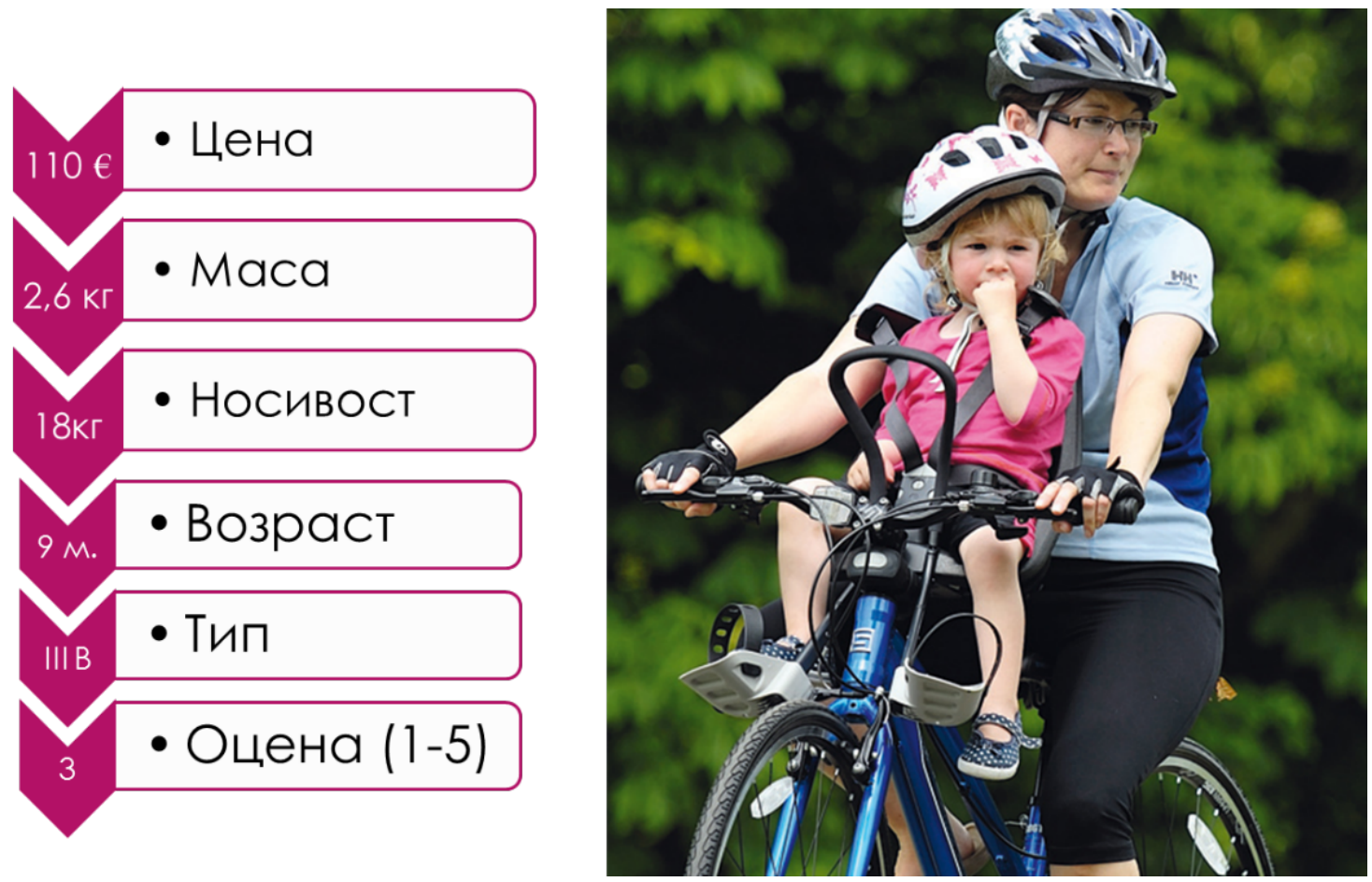

Слика 7 - Спецификации и реална примена на Yepp mini 

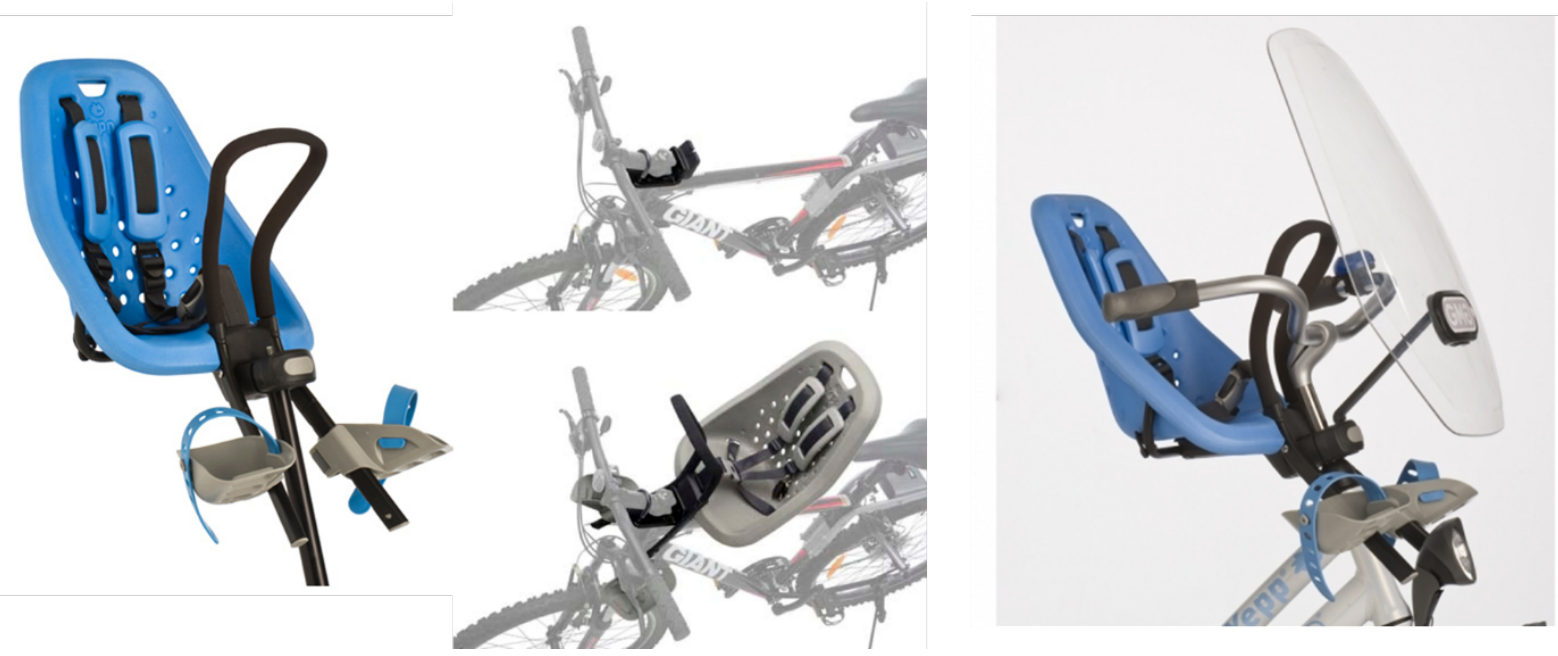

Слика 8 - Поставување на велосипед на Үерр mini со специјалните адаптери за градски и планински велосипед

\subsubsection{Yepp maxi}

Ова е втората варијанта на Холандскиот бренд Үерр, која е наменета за поголеми деца. Ги содржи истите карактеристики како и претходниот модел, со таа разлика што има појачана конструкција заради зголемената маса на детето.
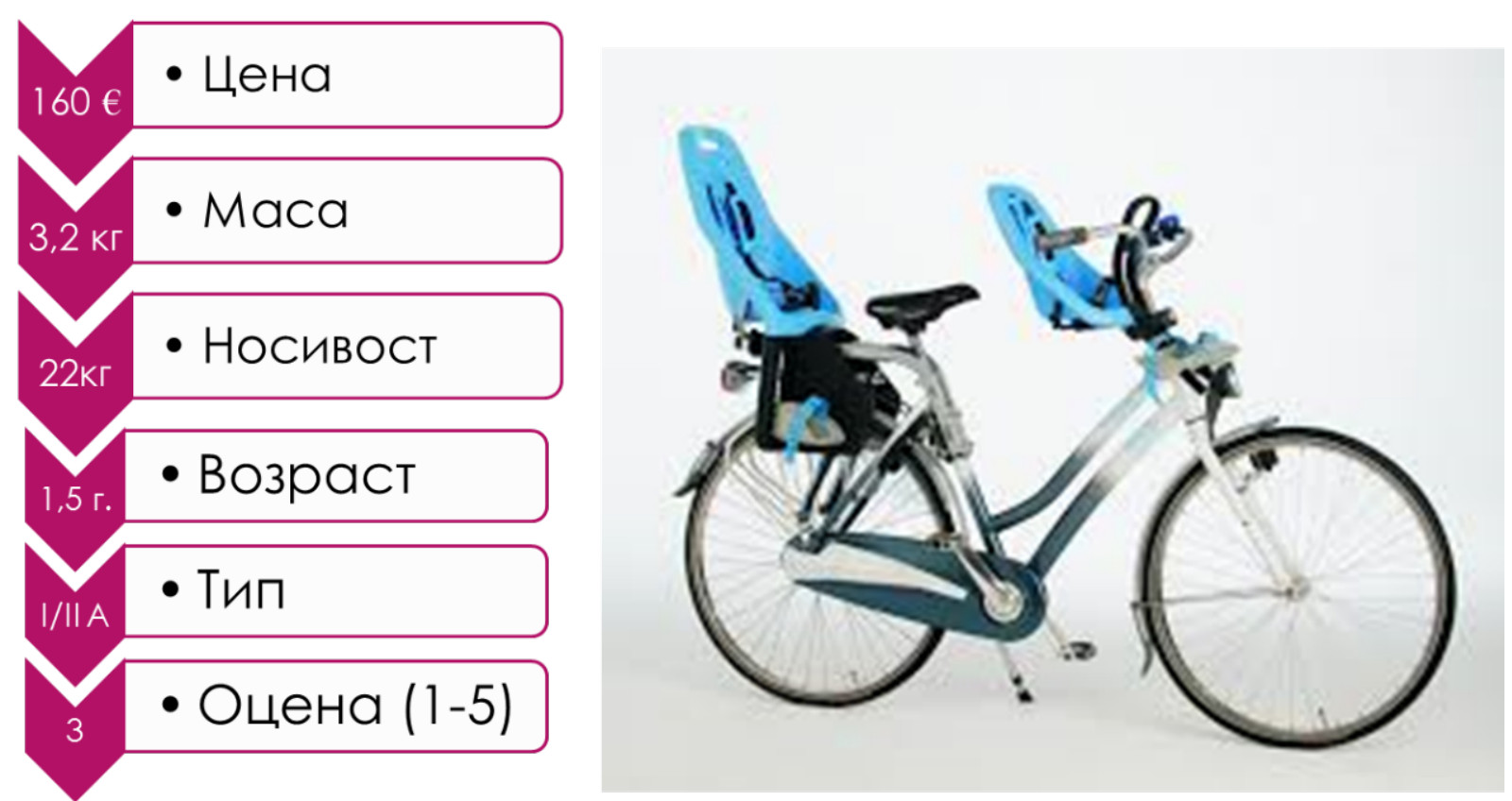

Слика 9 - Спецификации и реална примена на Үерp maxi и mini на истиот велосипед 


\subsubsection{OKBaby Orion}

Преден модел на седиште конкуретно на пазарот со голема безбедност, предно потпирање, променлива висина на потпирачите, мала маса и систем за заклучување.

Негативните страни се состојат во тешката и комплицирана монтажа и отсуството на променлив агол на наклон. Наменето е за деца од 7 месеци, за разлика од повеќето модели кои се за деца постари од 9 месеци.
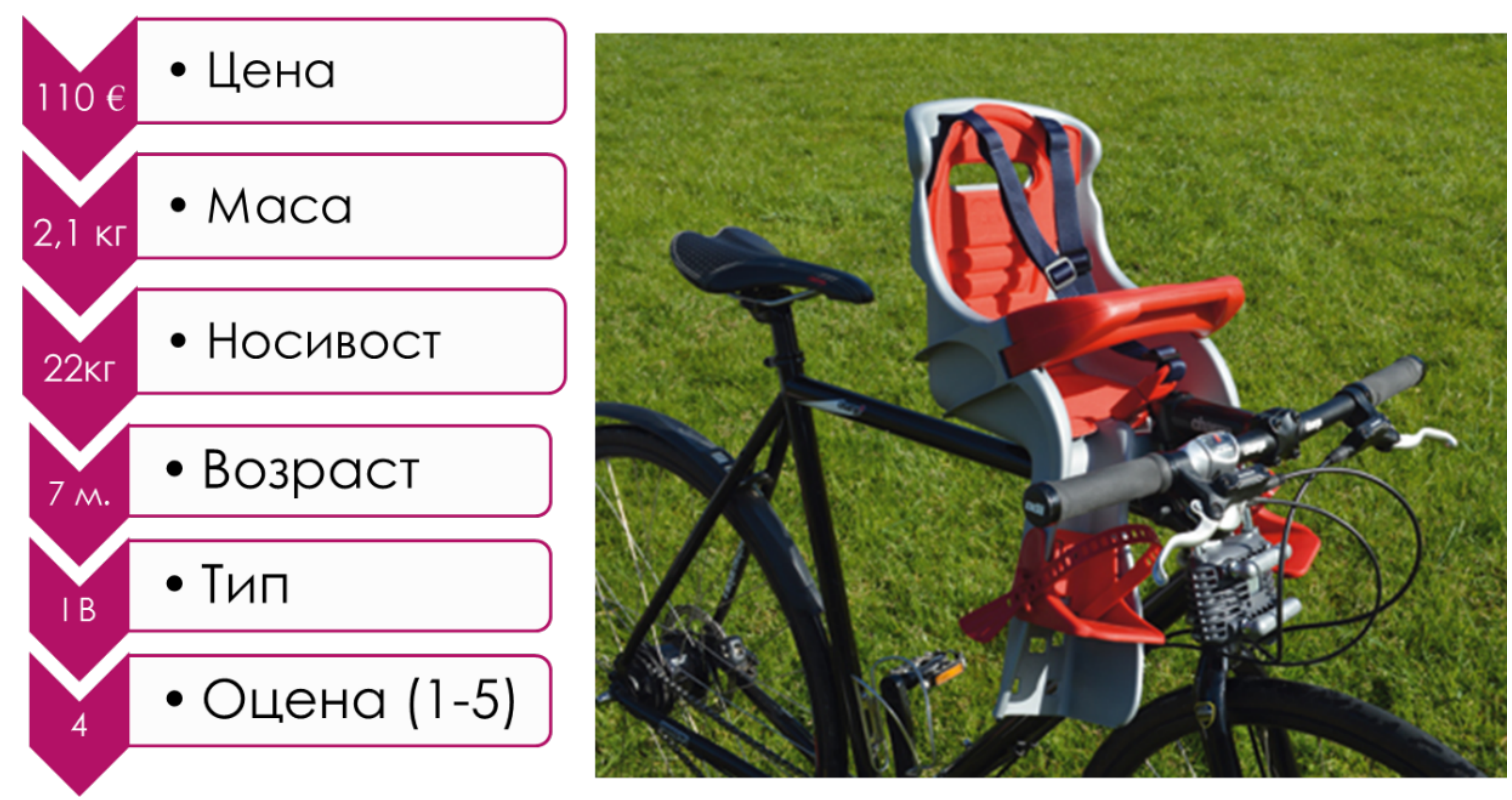

Слика 10 - Спецификации и реална примена на OKBaby Orion

\section{4 Споредба на различните алтернативи}

Како најдобри седишта според родителите - велосипедисти можат да се одвојат Hamax Caress, Hamax Kiss и ОКBaby Orion. Според мене Yерр Mini и Махі исто така би требало да припаѓаат на оваа група, бидејќи имаат незначително полоши карактеристики, во поглед на лесна монтажа, конструкција и удобност при возењето, но котира повисоко во однос на според мене еден од најважните критериуми- задоволството на децата. 


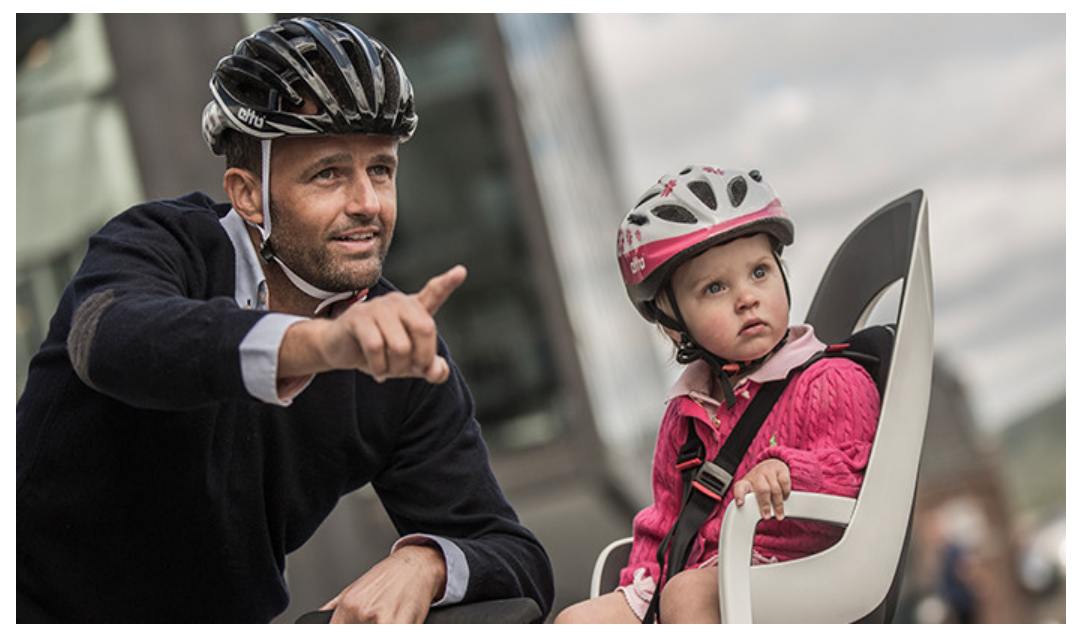

Слика 11 - Hamax Caress

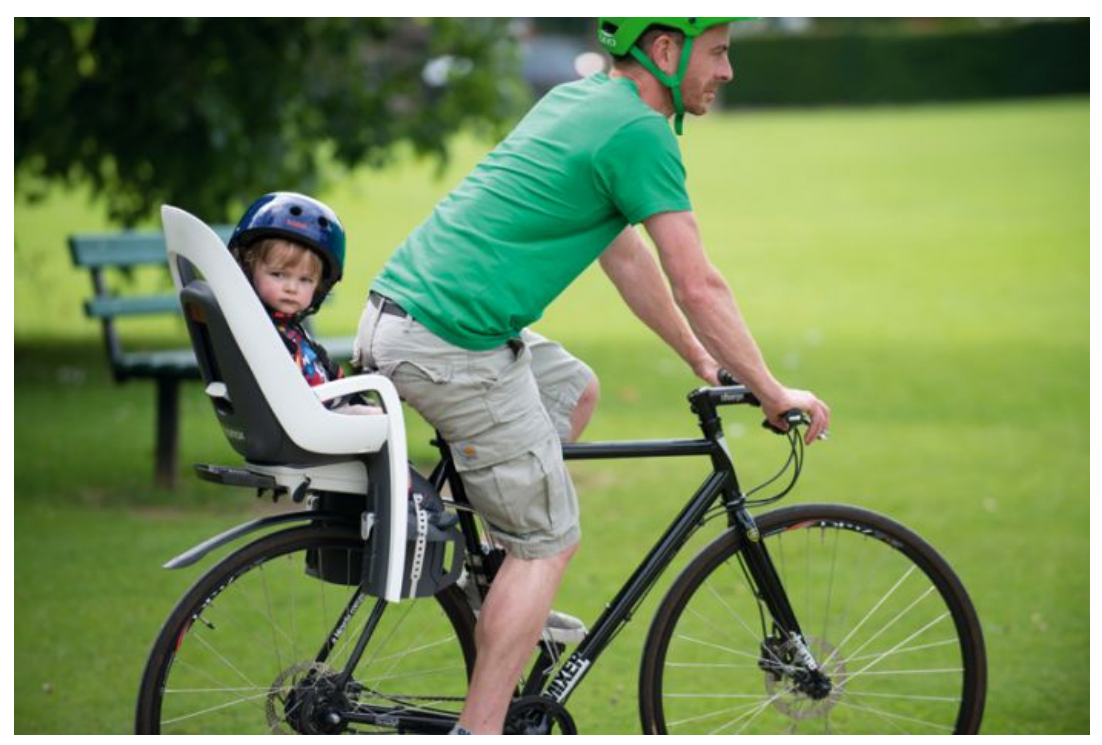

Слика 12 - Hamax Caress

Сепак, не смее да се занемари цената, која кај повеќето модели е доста висока, бидејќи одбрав модели кои се на врвот на листите за оваа проблематика, па според тоа добриот дизајн значи и скап производ. Во тој поглед, најисплатливо седиште е Hamax Kiss.

За крај, може да се заклучи дека секое од седиштата е добро на свој начин, во зависност од потребата- возраста на детето, типот на велосипедот, навиките за возење и висината на возачот.

Притоа, од возраста зависи големината, материјалот и носивоста на седиштето, типот на велосипед ја одредува потребата од специјален адаптер за монтажа, а од висината на возачот зависи дали детето ќе му пречи со главата и нозете при возењето. 

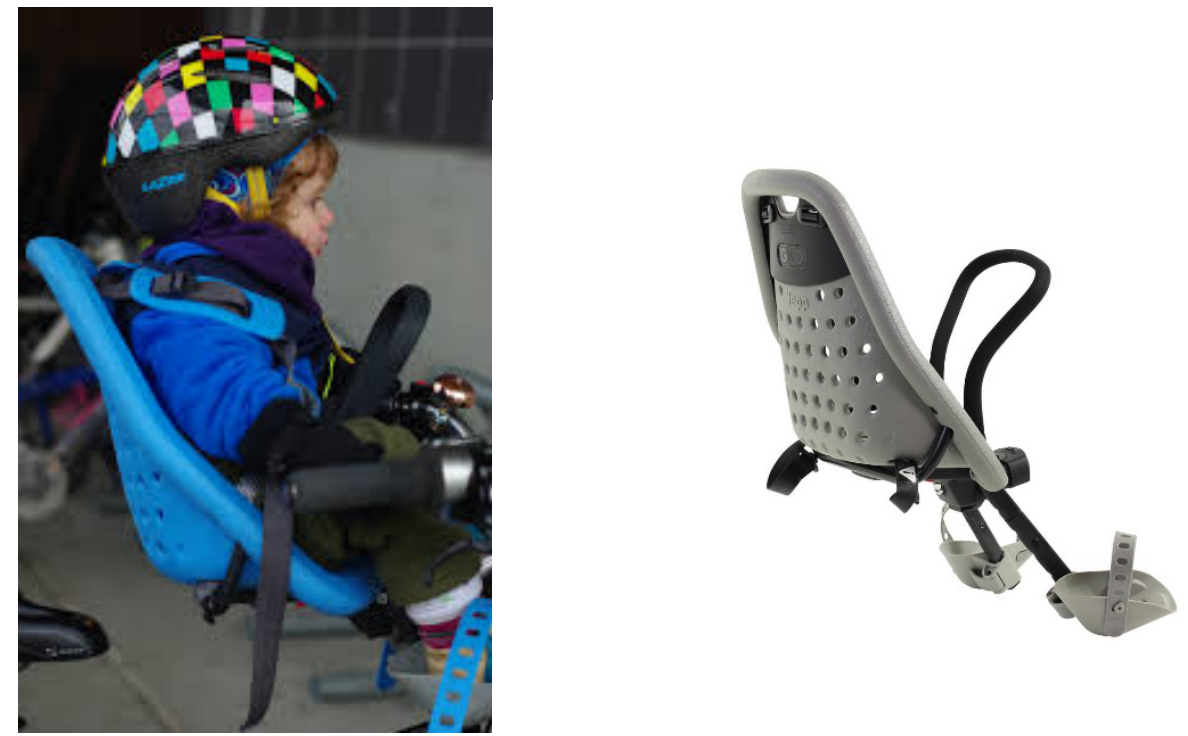

Слики 13 и 14 - Yepp mini

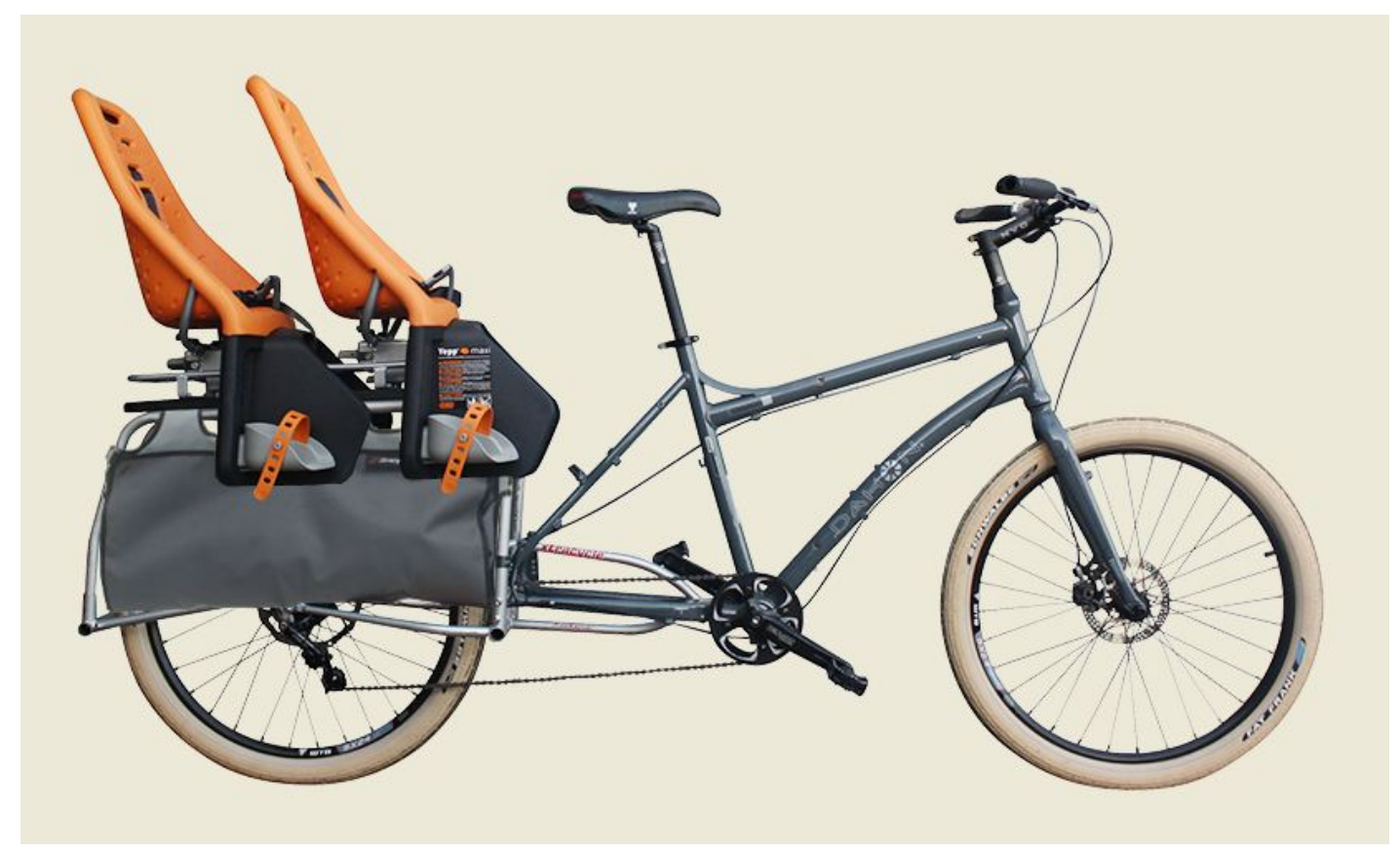

Слика 15 - Yepp maxi 


\section{4 Дефинирање на карактеристиките на новиот}

\section{концепт на велосипедско седиште за превоз на деца}

Досегашните истражувања на постоечките детски седишта за велосипед се однесуваа на светско ниво бидејќи пребарувањето беше направено на интернет со цел да се добијат што е можно повеќе информации за различните алтернативи и нивните спецификации, како и мислењето на корисниците.

Сепак, за потребите на овој дизајн спроведов истражување на македонскиот пазар, бидејќи нашите културолошки разлики не се занемарливи во споредба со останатите народи од Европа. Секојдневните навики и начинот на размислување во голема мера влијаат на фрактот дали македонските велосипедисти би потрошиле дел од своите приходи за едно вакво седиште, и кои се најважните карактеристики на истото.

\section{1 Анализа на резултатите од анкетата}

Анкетата која ја спроведов беше наменета за луѓе кои често возат велосипед, претежно од Скопје, иако имаше и испитаници од Битола и Охрид. Нивниот сооднос не го претставив процентуално бидеќи како податок не е релевантен за конкретната проблематика. Анкетата ја одговорија вкупно 31 испитаник, што иако не е голем број, во овој случај е доволен, затоа што нашето поднебје нема голем број на типични претставници на целната група луѓе кои би возеле велосипед заедно со мало дете.

Првото прашање се однесува на зачестеноста на возење велосипед. $61,3 \%$ од испитаниците одговориле дека возат неколку пати неделно, што е повеќе од задоволителен процент. Овде е интересно тоа што бројот на луѓе кои одговориле дека возат секој ден, е еднаков со оној на луѓе кои воопшто не возат велосипед, што на некој начин ја балансира ситуацијата со велосипедизмот во нашата земја.

Останатите 19,4\% кои возат неколку пати годишно, се рекреативци кои возат само преку лето, на кеј или некои други кратки дестинации. 


\section{Колку често возите велосипед? (31 responses)}

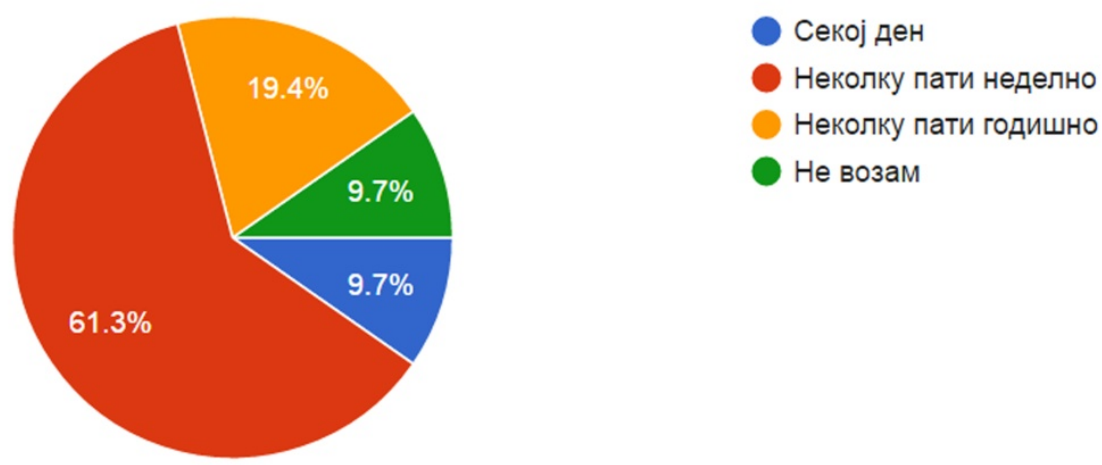

Графрикон 1 - Зачестеност на возење велосипед

Второто прашање се однесува на делот од денот кој го користат луѓето за оваа активност. Ова е важно за одредување на материјалите од кои би се изработило седиштето. Бидејќи 25 испитаници, кои претставуваат 83,3\% од вкупниот број најчесто возат претпладне, потребно е материјалот да биде отпорен на загревање и ладење, бидејќи во Скопје може да има значителна температурна разлика за временска разлика од неколку часови. На пладне во лето може да достигне и до $45^{\circ} \mathrm{C}$, што би предизвикало загревање на седиштето ако стои на сонце додека патникот има обврски. Од друга страна $30 \%$ од испитаниците одговориле дека возат рано наутро, веројатно за на работа или училиште, кога температурите знаат да бидат драстично различни, особено во Скопје.

Кога најчесто возите велосипед? (30 responses)

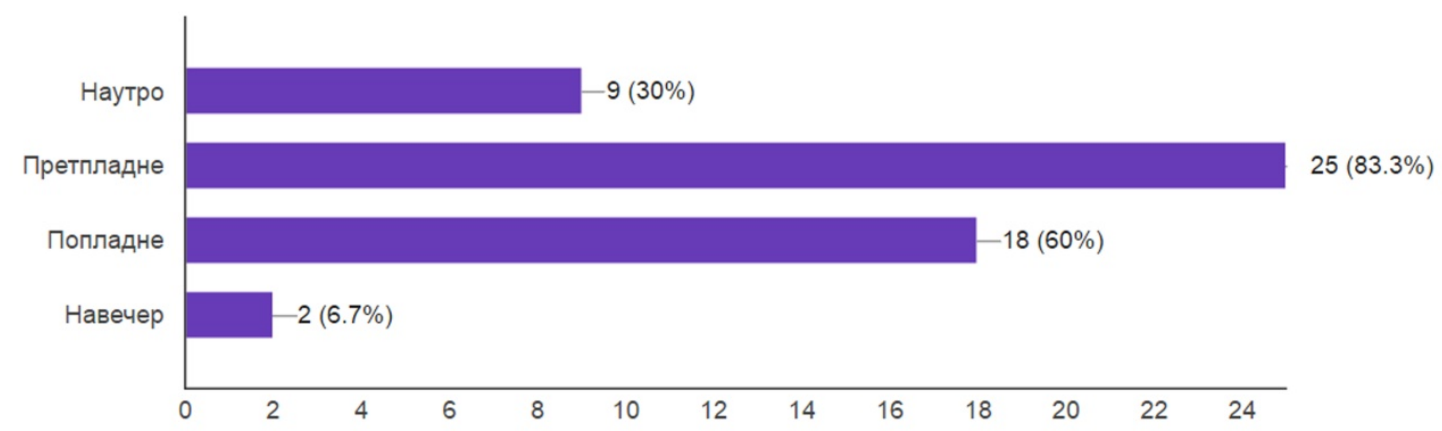

Графикон 2 - Дел од денот за возење велосипед 
Следното прашање одредува дали испитаниците во досегашното искуство се имаат возено на велосипед заедно со мало дете. Јас сум сведок на повеќе такви случаи, кога повеќе деца се возат на еден велосипед, но тоа се несериозни обиди на кратки релации (пр. до најблиската продавница) и не припаѓаат во доменот на ова истражување.

Дури $77,4 \%$ од испитаниците го имаат моето искуство, што значи дека кај нас ова не е нешто непознато.

Дали сте возеле мало дете на велосипед? (31 responses)

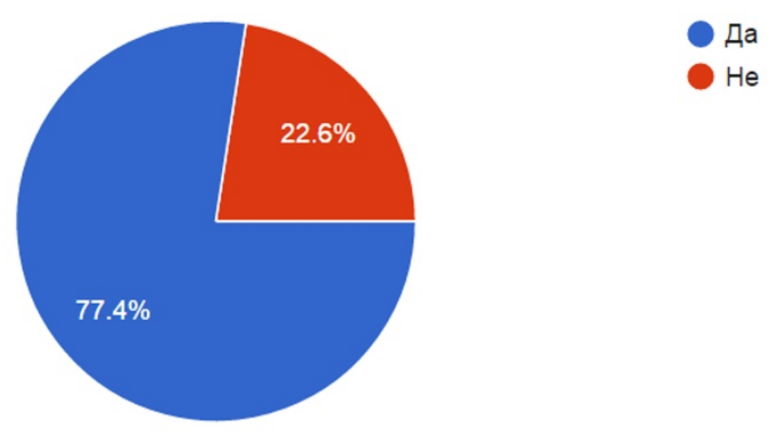

Графикон 3 - Застапеност на повеќе од еден патник на велосипед

Од друга страна, четвртото прашање открива уште поинтересен фактдека на голем велосипед се возело дете без детско седиште во $67,7 \%$ од случаите. Овој фракт е од големо значење за оваа магистерска работа, бидејќи открива препознавање на потреба за која не сме биле доволно свесни досега. Тоа значи не дека немало потреба од ваков производ, туку дека потрошувачите воопшто не размислувале на таа тема - да се купи детско седиште за велосипед, бидејќи застапеноста на ваквите седишта на македонскиот пазар била мала, и со тоа недоволна за да се забележи поголем број на вакви случаи меѓу толпата случајни минувачи.

Од друга страна, 32,3\% е процентот на луѓе кои веќе имаат вакво седиште. Претпоставувам дека тоа се купувачи кои се во тек со трендовите кои се актуелни и се надевам дека оваа пракса ќе се прошири што побрзо меѓу луѓето, бидејќи од неа зависи како удобноста при возењето, така и безбедноста на децата во сообраќајот. 


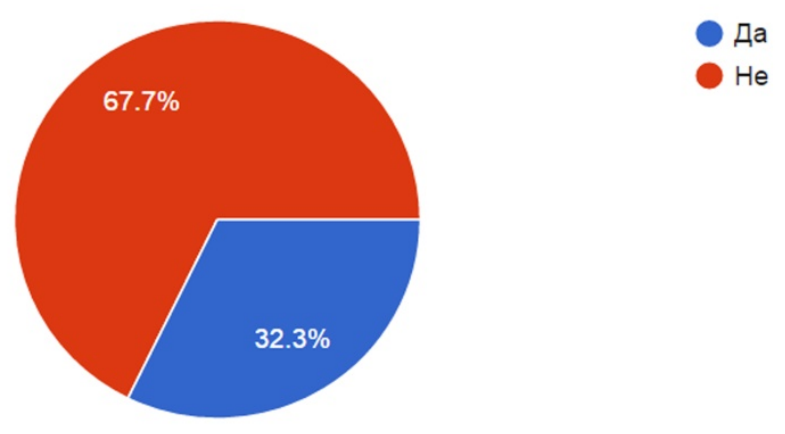

Графикон 4 - Користење на детско седиште

Особено поволен е и фрактот дека $90 \%$ од вкупните испитаници мислат дека ваквото детско седиште е дефинитивно исплатлива инвестиција, бидејќ се купува еднаш, а може да се користи се додека детето е доволно возрасно за да вози свој велосипед. Тоа подразбира дека тоа ќе може да дојде на најразлични дестинации заедно со семејството, од градски тури, низ зоолошката градина или парк, па се до тури во природа.

Дали мислите дека детско седиште за велосипед е исплатлива инвестиција?

(30 responses)

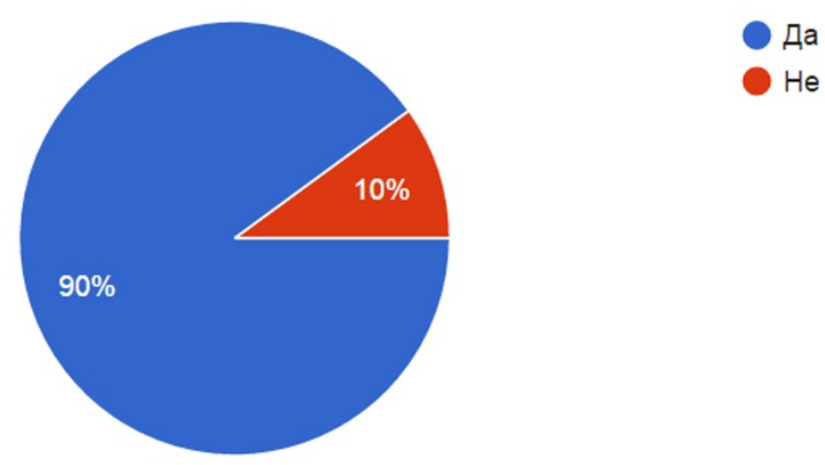

Графикон 5 - Мислење на купувачите за исплатливоста на детско седиште

Шестото прашање бара од испитаниците да одберат клучен критериум за купување на ваквото седиште. Притоа, во најголем процент $(74,2 \%)$ се појаува безбедноста на децата, што е сосема очекувано и природно за секој родител. На второ место со $71 \%$ е носивоста, односно максималната маса на детето кое се вози во седиштето. Овој податок е важен за дефинирање на инженерските 
спецификации, бидејќи зависи од видот на носечката конструкција и материјалот од кој е изработено.

На трето и четврто место се лесната монтажа $(51,6 \%)$, која треба да биде добро обмислена за да резултира во интуитивен дизајн кој лесно ќе се поставува на адаптерот за велосипед и цената $(38,7 \%)$, која не треба да не изненадува што е дури на четвртото место бидејќи се работи за дизајн наменет за мали деца. Иако живееме во земја со многу низок стандард, самата природа на овој производ значи дека испитаниците се спремни да инвестираат во спорт и добро здравје, што значи дека припаѓаат барем на средната класа, на кои цената не им е приоритетен критериум, особено не пред безбедноста. Остатокот од испитаниците им придаваат значење на дизајнот (изгледот) и тежината на самото седиште, која треба да биде што помала за да се олесни возењето.

Кој е клучниот критериум за купување на детско седиште ? (31 responses)

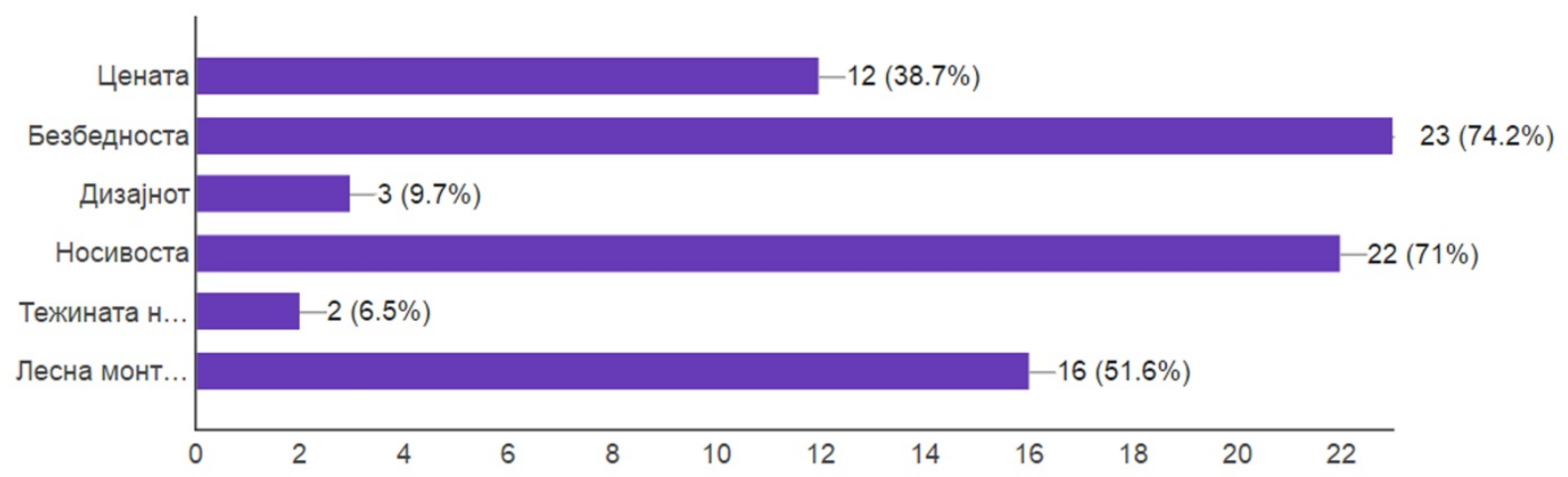

Графикон 6 - Мислење на купувачите за клучниот критериум кај детско седиште

Седмото прашање ја одредува преференцијата на испитаниците на седиште кое би се монтирало пред или зад возачот. Иако задните седишта доминираат со 58,1\%, не смее да се занемарат предните седишта со 41,9\%, бидејќи овие проценти се многу блиску еден до друг. Идеалното решение на овој проблем ќе биде обид да се направи седиште кое по потреба може да биде и предно и задно, во зависност од возраста на детето. 
Каков тип на седиште преферирате? (31 responses)

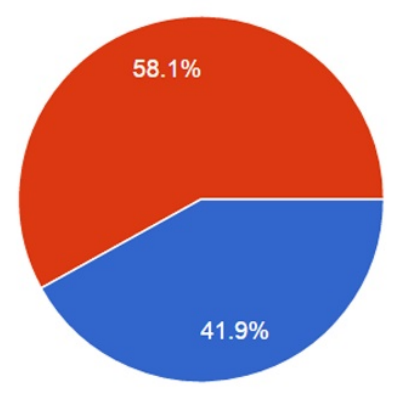

Предно (детето седи пред возачот)

задно (детето седи зад возачот)

Графикон 7 - Преференција на купувачите за тип детско седиште

Осмото прашање е во голема мера поврзано со претходното. Од досегашното истражување на интернет за пазарот на детските седишта заклучив дека задните седишта носат поголема маса и затоа се наменети за постари деца, и тоа од 2 години па нагоре. Има и седишта за над 4 години, но се доста скапи и неисплатливи, бидејќи се работи за големи товари кои се непотребни, бидејќи децата веќе можат да возат сами свој велосипед. Голем е и процентот на луѓе кои имаат деца под 2 години, а би сакале да ги возат на велосипед $(41,9 \%$ ). Значи се бара инженерско решение кое би ги задоволило двете целни групи во еден производ.

За која возраст на дете би одбрале седиште за велосипед? (31 responses)

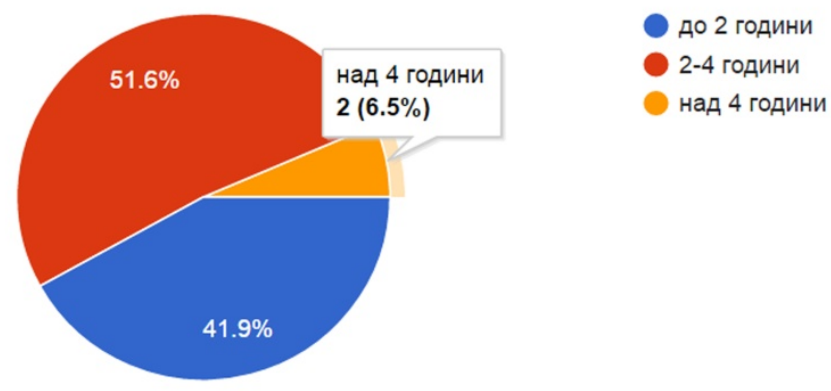

Графикон 8 - Возраст на детето при купување на детско седиште

Според купувачите, најголемата предност на едно детско седиште е можноста да се користи што е можно подолго (45,2\%). Доколку успеам да ги обединам двете целни групи, седиштето би достигнало максимална 
исплатливост, за разлика од другите конкуренти кои нудат различни седишта за различни возрасти, а со тоа и зголемени трошоци.

Овде како понуден одговор ја вметнав идејата за дизајн кој може да се монтира и како предно и како задно седиште, со цел да ги препознаам барањата на корисниците, иако тоа доста ја комплицира неговата конструкција. Остатокот од одговорите отпаѓаат на атрактивен изглед, лесно качување и симнување и компатибилноста со различни велосипеди.

\section{Што според вас е најголемата предност на едно детско седиште за велосипед? \\ (31 responses)}
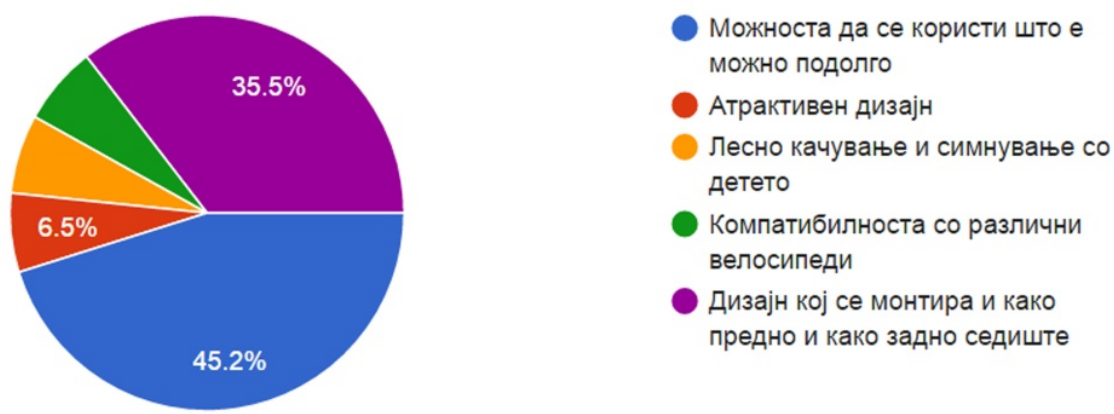

Компатибилноста со различни велосипеди

Дизајн кој се монтира и како предно и како задно седиште

Графикон 9 - Предност при купување на детско седиште

Бидејќи веќе стекнав ориентација околу тоа што точно сакаат купувачите од едно вакво седиште, следува прашање за тоа што не им се допаѓа кај постоечките варијанти. Моделите кои ги има кај нас се претежно ефтини, со лош квалитет и кратко траат, па веројатно затоа 54,8\% одговориле дека би ја подобриле издржливоста. Во претходното истражување имаше бројни примери на негативни забелешки околу сигурносниот појас за детето, тешко отклучување, или лесно отклучување и недоволно безбедно итн. Овде тој факт се потврдува - 48,4\% би го подобриле сигурносниот појас. 9,7\% од потрошувачите мислат дека седиштата треба да бидат поефтини, а $6,5 \%$ со подобар изглед. 


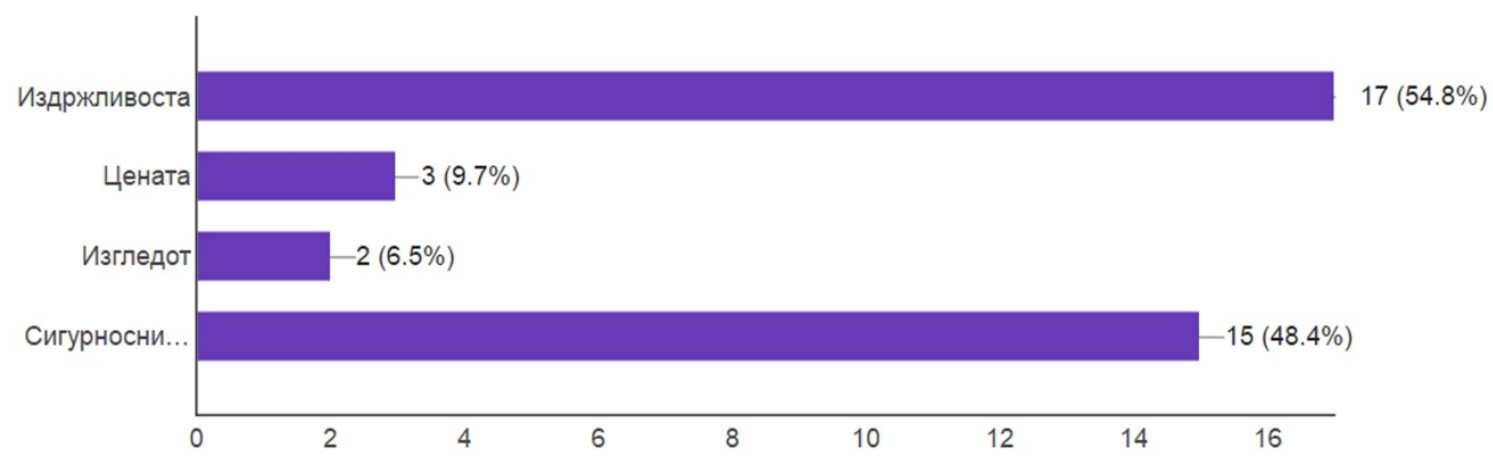

Графикон 10 - Подобрувања кај детските седишта

Од претпоследното прашање може да се заклучи дека во однос на полот, нема големи разлики $(48,4 \%$ наспроти $51,6 \%)$ за тоа кој повеќе вози деца на велосипед, мажите или жените.

Пол (31 responses)

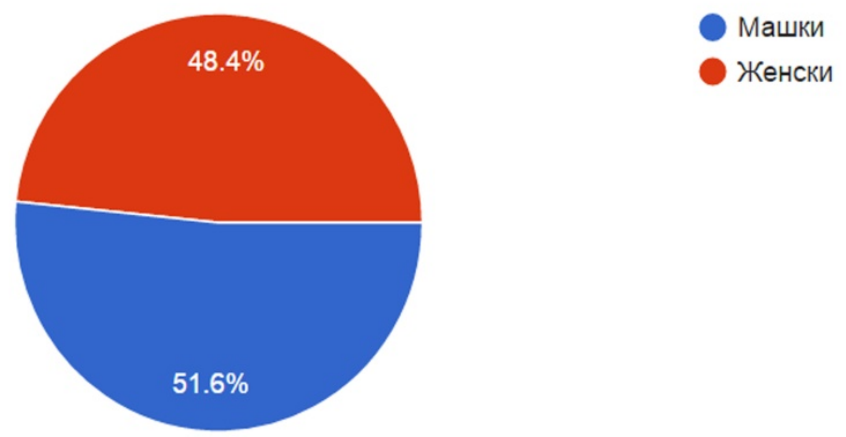

Графикон 11 - Пол на испитаниците

Последното прашање, кое се однесува на возраста на испитаниците ни дава претстава за тоа кој ја сочинува целната група на купувачи на детско седиште. Најголем процент $(54,8 \%)$ отпаѓa на луѓе од 30-50 години, што е логична возраст за просечниот родител со мали деца. Доста голем процент (35,5\%) зафаќa и групата од 15-30 години, што веројатно се дели на две подгрупи: постарите браќа и сестри на децата кои би се возеле во седиштето (15-25), како и млади родетели (25-30 години). Мал дел отпаѓa на испитаниците 
над 50 години, кои би биле баби и дедовци на децата, а би требало да имаат повеќе време за да им посветат на внуците, поминато во возење велосипед.

\section{2 Заклучок од анкетата}

Како заклучок од анкетата се извлечени неколку клучни карактеристики, дефинирани во вид на барања на корисниците, неопходни за конструирање на новиот концепт на детско седиште:
○ да се користи за деца од 0-5 години со можност за прилагодување;
о да биде економски исплатливо;
○ да се користи што е можно подолго;
○ да биде наменето за честа употреба;
○ да биде од материјал кој не апсорбира топлина;
○ да биде безбедно;
о голема носивост и лесна монтажа;
○ голема издржливост;
- да има сигурносен појас кој е лесен за употреба. 


\section{5 Инженерски специфрикации и QFD дијаграм}

Со примена на QFD методот, познат како Куќа на квалитет, се извлечени конкретни инженерски спецификации, како целни карактеристики со кои би се обезбедил поквалитетен производ од конкурентските, а се неопходни во процесот на конструирање и моделирање на новиот концепт.

Во првата колона на куќата на квалитет се поставени претходно дефинираните барања на корисниците.

Дефинирани се две таргет групи на корисници: родителите, кои треба да го купат седиштето, и децата, кои треба да го користат, декларирани во следните две колони од куќата на квалитет. Потоа е извршено рангирање на поединечните барања на корисниците според степенот на важност за посебните таргет групи. Така, на пример, за родителите најважна би била безбедноста, квалитетот на изработка и цената, додека за децата удобноста, изгледот и боите.

Во 12-те следни колони се сместени инженерските карактеристики кои се избрани така да претставуваат соодветно инженерско решение на барањата на корисниците, а што е особено важно - да биде мерливо. Потоа е извршено дефинирање на зависноста меѓу барањата на корисниците и инженерските карактеристики, како и на карактеристиките меѓусебно, со оценка 1, 3 и 9 (1 мала, 3 - средна и 9 -голема зависност). Избраните три конкурентски седишта (наброј ги), декларирани се во трите крајни колони на куќата на квалитет. Тие се оценети за секоја карактеристика со оцена од 1 до 5.

Во долните редови на куќата на квалитет повторно се декларирани трите конкурентски седишта, а за нив во соодветните редови се сместени точни податоци за секоја од декалираните инженерски карактеристики со цел да бидат споредливи меѓусебно. Конечно, во долниот ред се извлечени заклучоци од извршената споредба со цел карактеристиките на новиот концепт на детско седиште да бидат подобри од конкурентските. 


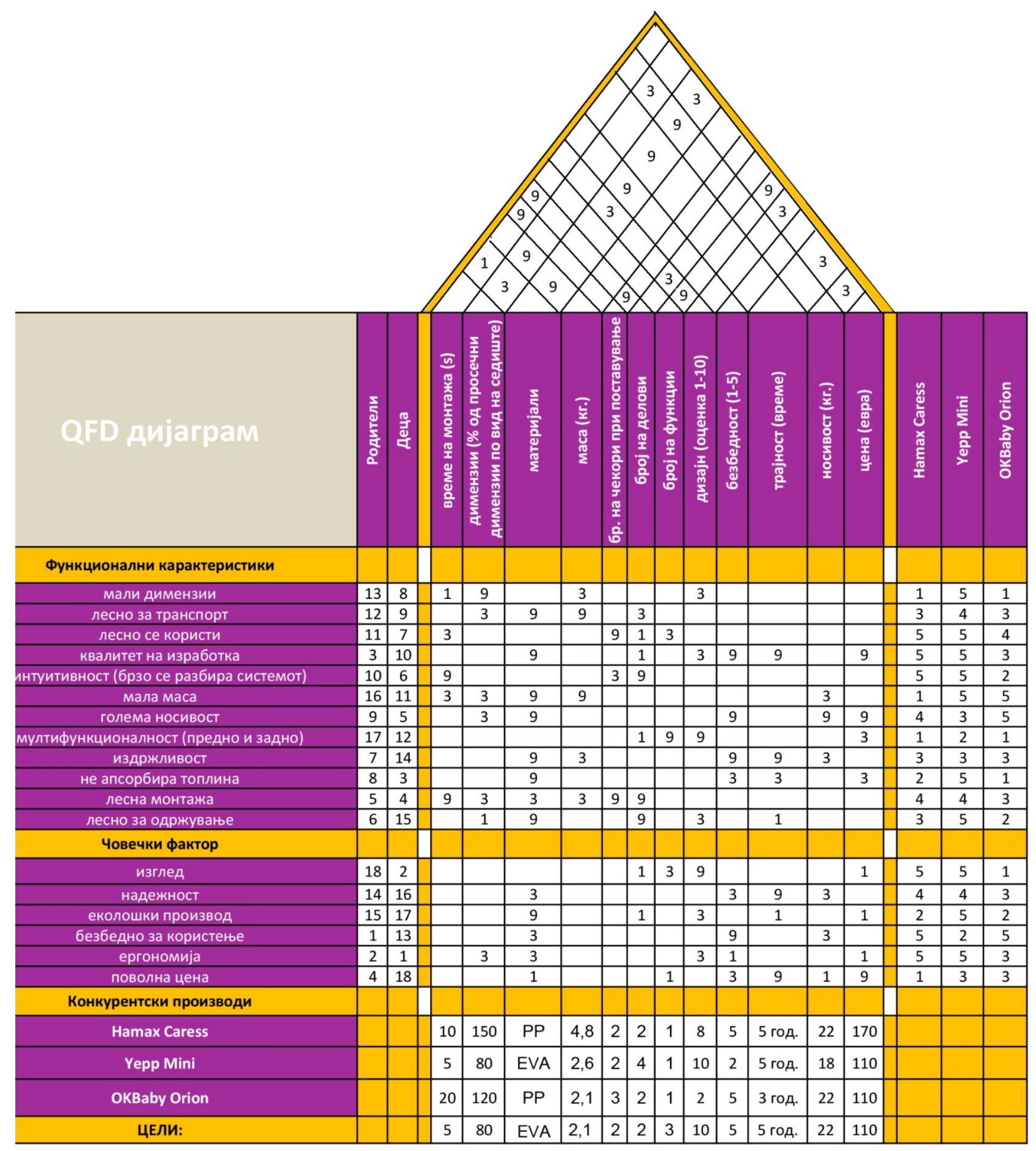

Дијаграм 1 - Куќа на квалитет за детско седиште за велосипед 


\section{1 Конечни цели за дизајн на велосипедско седиште за превоз}

\section{на деца}

Резултат од извршената нализа со помош на QFD методот е конечна листа на инженерски специфрикации кои треба да ги задоволува дизајнот велосипедско седиште за превоз на деца:

- При поставен адаптер, седиштето да се монтира/демонтира за 5 секунди;

- Намалени димензии кои во однос на останатите конкурентските седишта (80\% од просечните димензии);

○ Да биде изработено од ЕВА полимер;

- Да има маса до 2,1 кг;

- Да се поставува во два чекори;

- Кога е еднаш склопено да биде составено од два главни делови;

- Да има повеќе од една фуннција;

- Да има одличен дизајн;

- Да биде доволно безбедно;

- Да трае минимум 5 години;

- Да има носивост од 22 кг. и

- Да има цена од максимум $110 €$. 


\section{6 Антропометриски мерки неопходни за правилно}

\section{димензионирање на седиштето}

Ергономијата во контекст на детско седиште за велосипед е една од најважните точки во оваа магистерска работа, пред се поради фактот дека се работи за дизајн за бебиња и мали деца, чие тело е во фаза на растење и од особено значење е димензиите, аглите и мерките за седење да бидат правилно одредени за постигнување оптимална удобност и непречен развој, особено поради тоа што седиштето е наменето за честа и долготрајна употреба.

Ергономијата на седењето кај децата почнува да се разгледува од наполнети 6 месеци, бидејќи тие учат да седат токму од оваа возраст. Поради тоа и повеќето понудени варијанти на пазарот на детски седишта се наменети за навршени 9 месеци, кога тие веќе без проблем можат сами да седат. Мојата идеја за имплементирање на рангот 0-5 години за возраст кај новото седиште не е опасна по анатомскиот развој на бебињата, бидејќ е предвидено тие да бидат во полулежечка положба, како во седиштата за во автомобил. Со тоа се избегнува оптоварувањето на рбетниот столб во првите неколку месеци на користење, додека околната мускулатура не се зајакне и развие.

\section{1 Дефинирање на неопходни антропометриски мерки}
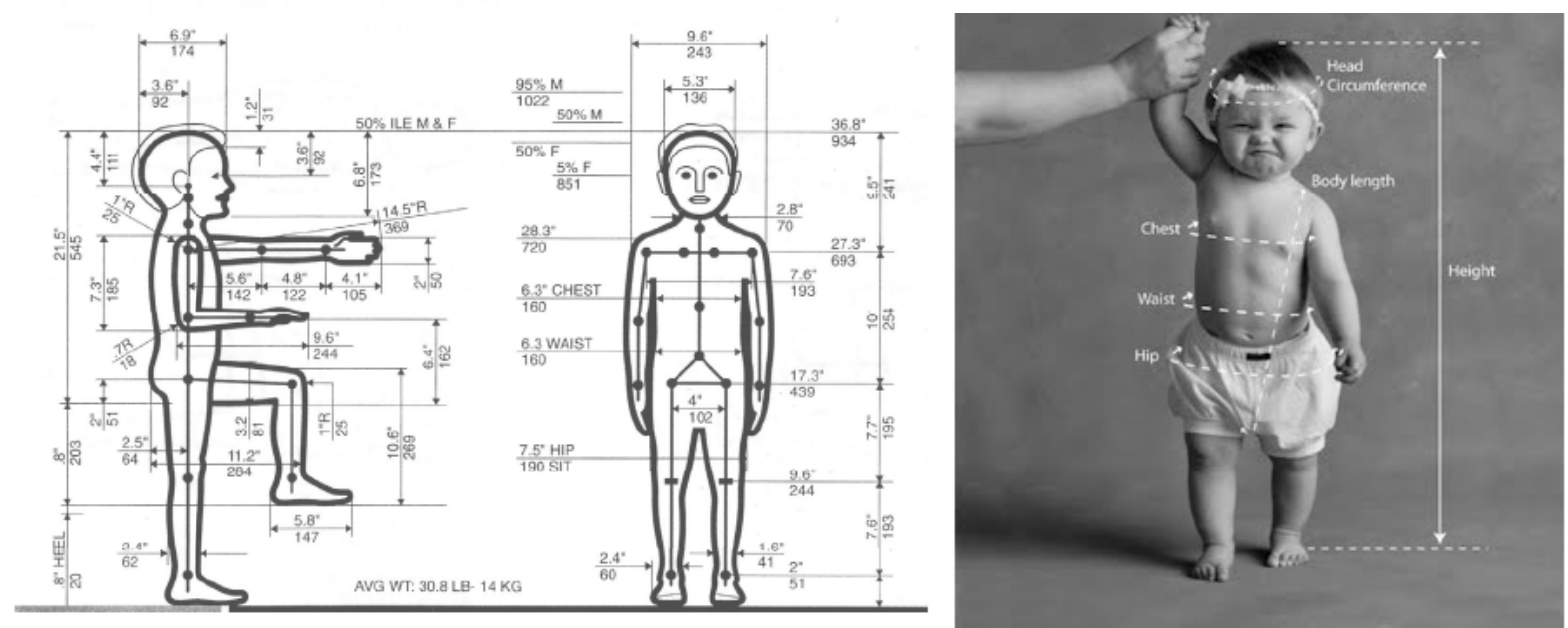

Слики 1 и 2 - Антропометриски мерки кај доенчиња и мали деца 
Концептот на слоеви со кој се постигнува прилагодување на димензиите на велосипедско седиште за различна возраст на корисниците бара детално проучување на антропомеријата на деца од различна возраст со цел правилно димензионирање и обликување на слоевите. Предвидено е прилагодувањето да биде овозможено со три дела - слоеви, предвидени за следните возрасти:

○ најмалиот дел за возраст од 0 до 1 година;

○ вториот дел би одговарал на мерките на дечиња од 1 до 3 години и

o третиот дел би бил наменет за возраст од 3 до 5 години.

Според извршената анализа на детската анатомија ги издвоив најважните и најрелевантни антропометриски мерки кои се потребни во дизајнот на детско седиште, презентирани на слика 3.

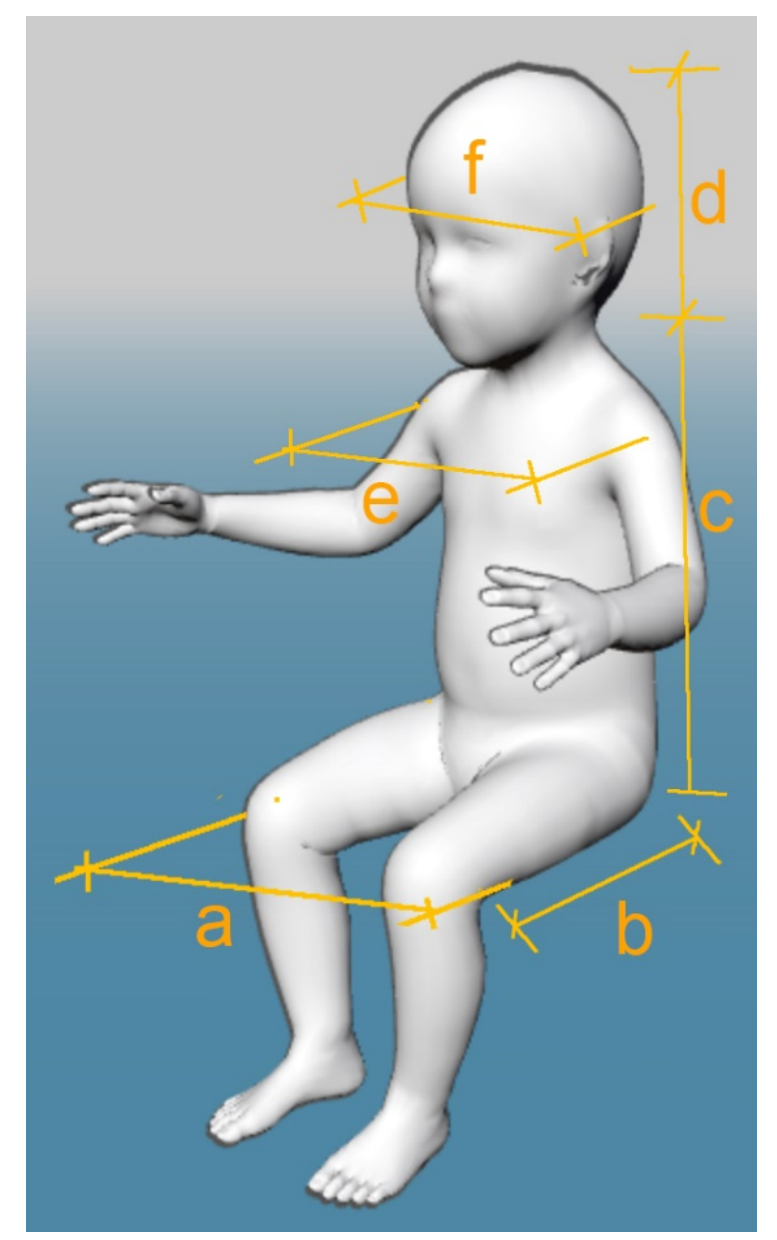

Слика 3 - Антропометриски мерки релевантни за дизајнот на седиштето 
Вредностите ${ }^{11}$ на секоја мерка посебно и за секој од трите слоја одделно, се презентирани во табелата 1.

\begin{tabular}{|c|c|c|c|}
\cline { 2 - 4 } \multicolumn{1}{c|}{} & \multicolumn{3}{c|}{ Слоеви од седиштето } \\
\hline Мерка (mm) & $\begin{array}{c}\text { Слој 1 } \\
\text { (до 1 година) }\end{array}$ & $\begin{array}{c}\text { Слој 2 } \\
(1-3 \text { год.) }\end{array}$ & $\begin{array}{c}\text { Слој } 3 \\
(3-5 \text { год.) }\end{array}$ \\
\hline Ширина на колкови (a) & 159 & 190 & 213 \\
\hline Должина на натколеница (b) & 194 & 284 & 358 \\
\hline Должина на трупот (c) & 319 & 371 & 442 \\
\hline Растојание од рамена до врвот на главата & 161 & 174 & 191 \\
\hline (d) & 208 & 243 & 278 \\
\hline Ширина на рамена (e) & 116 & 136 & 139 \\
\hline Ширина на глава (f)
\end{tabular}

Табела 1 - Антропометриски мерки за различни возрасти на деца

За секој слој од седиштето потребна е соодветна димензија која одговара на 85-ти перцентил за секоја мерка одделно од соодветната возраст. Пример, должината на натколеница за бебе од 1 година е многу помала од должината кај дете од 3 години, која пак е помала од онаа кај 5-годишно дете, што е сосема природно, бидејќи на оваа возраст децата најинтензивно растат. Не случајно го одбрав 85-ти перцентил за машки деца, бидејќи седиштето треба да биде во можност да ги собере и покрупните деца, додека со овој избор остануваат само 15\% од сите деца, припадници на белата раса од Европа, кои имаат поголеми мерки од презентираните. Не се одлучив да одам со 99 перцентил, поради тоа што во тој случај седиштето би било преголемо за поситните деца. Се разбира дека е природно девојчињата да бидат помали од момчињата на иста возраст, па затоа во антропометриските табели барав вредности за момчиња.

Мерките за деца кои се земени како готов податок од ергономското предавање одлучив да ги споредам со податоците од моето истражување, кое го спроведов со помош на 10 деца во една градинка во Скопје. Како што може

${ }^{11}$ R. Tilley Alvin, Dreyfuss Henry The Measure of Man and Woman: Human Factors in Design 1st edition, Associates 
да се види од табелата бр. 2, од секое дете собрани се податоци за претходно дефинираните неопходни мерки. Во дизајнот за моето седиште земав податоци од втората табела со оглед дека се работи за деца од нашиот регион, кој е таргет група на овој производ. За секоја мерка ги одбирав димензиите кои се поблиску до горниот екстрем, за да ги собере и покрупните деца.

\begin{tabular}{|c|c|c|c|c|c|c|c|c|c|c|}
\hline & \multicolumn{7}{|c|}{ Димензија за дете со реден бр. } \\
\hline & 1 & 2 & 3 & 4 & 5 & 6 & 7 & 8 & 9 & 10 \\
\hline Ширина на колкови (cm) & 18 & 22 & 23 & 25 & 24 & 24 & 26 & 32 & 23 & 25 \\
\hline $\begin{array}{c}\text { Должина на натколеница } \\
(\mathrm{cm})\end{array}$ & 15 & 22 & 25 & 26 & 25 & 29 & 35 & 33 & 30 & 33 \\
\hline Должина на трупот (cm) & 23 & 32 & 32 & 40 & 54 & 32 & 38 & 40 & 35 & 36 \\
\hline $\begin{array}{c}\text { Растојание од рамена до } \\
\text { врвот на главата (cm) }\end{array}$ & 16 & 20 & 20 & 21 & 22 & 20 & 21 & 19 & 18 & 18 \\
\hline $\begin{array}{c}\text { Ширина на рамена (cm) } \\
\text { Ширина на глава (cm) }\end{array}$ & 20 & 23 & 25 & 15 & 25 & 24 & 32 & 32 & 25 & 24 \\
\hline Висина (ст) & 73 & 85 & 95 & 106 & 104 & 107 & 124 & 111 & 115 & 107 \\
\hline Маса (kg) & 10 & 11 & 17 & 20 & 19 & 18 & 28 & 24 & 13 & 19 \\
\hline Возраст (год.) & 0,8 & 2 & 3 & 4 & 4 & 5 & 5 & 5 & 6 & 6 \\
\hline
\end{tabular}

Табела 2 - Мерки на децата кои учествуваа во ергономското истражување

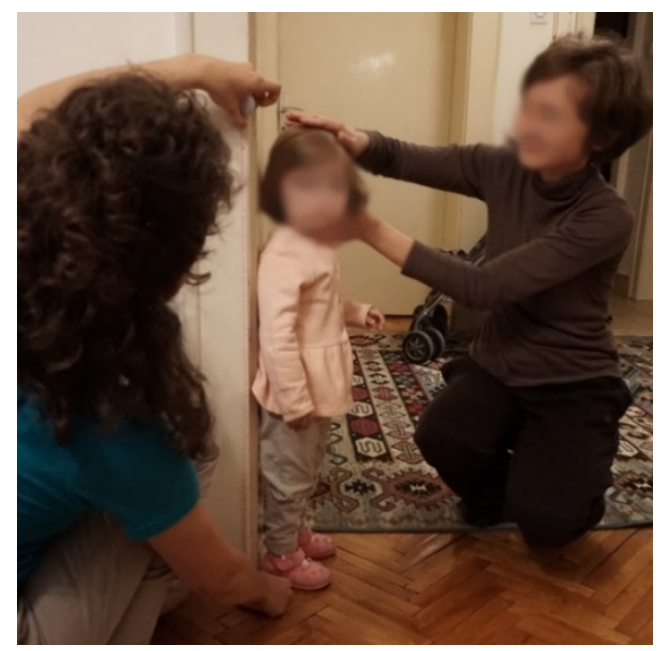

Слика 4 - Земање мерки од децата испитаници 


\section{7 Ергономска анализа на удобноста на седењето на}

\section{производи наменети за деца}

Со цел да се обезбеди поголема удобност на седиштето беше неопходно да се изврши анализа на распределбата на притисокот, односно максималниот притисок кој се јавува помеѓу корисникот (детето) и седиштето, испитано кај неколку детски производи наменети за седење. За испитување на распределбата на притисок користев мерна опрема од производителот XSENSOR Technology Corporation. ${ }^{12}$ Мерната опрема се состои од неколку елементи:

- Сензорска платфрорма X3 PRO,

- Перниче за мерење на распределбата на притисок,

- XSENSOR софртвер - X3 MEDICAL v6.0,

- Mini - B USB кабел,

- 12 VDC 3.75 A AC/DC трансформатор за струја,

○ Електроника за спојување помеѓу перничето и компјутерот,

- X3 node $и$

○ Компјутер.

Во продолжение се претставени резултатите од ергономското истражување спроведено кај 10 деца на возраст од 9 месеци до 6 години (истите од претходната табела, на три различни седишта со помош на спомнатата мерна опрема).

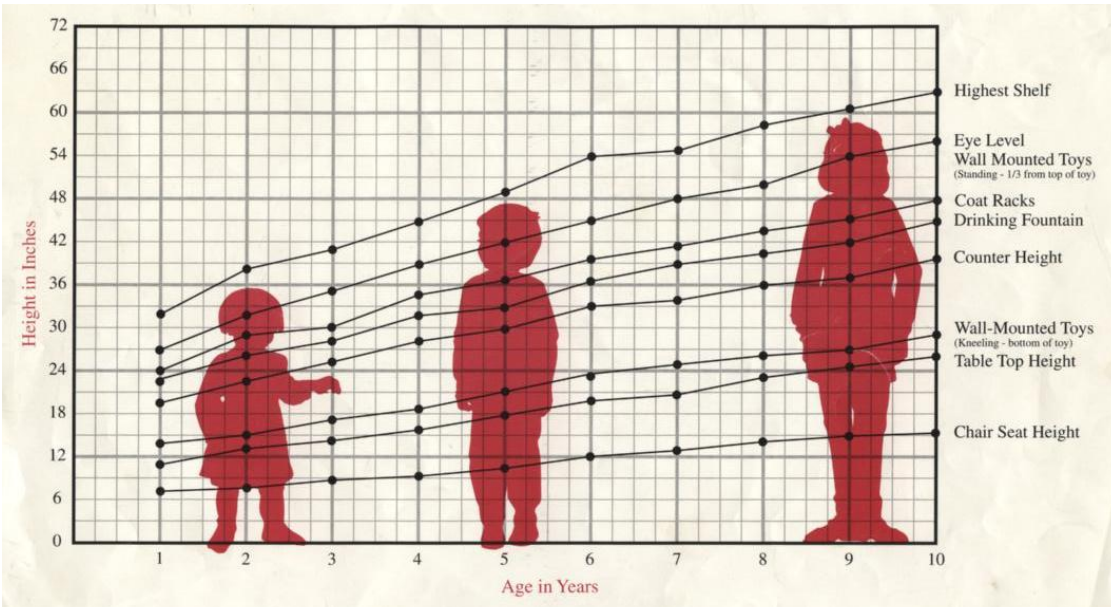

Слика 1 - Претставници на деца од различни возрасти

\footnotetext{
${ }^{12}$ Мирчески Иле, (2009) Нумеричко моделирање и анализа на удобноста на возачкото седиште кај патнички автомобил, магистерска работа стр. 73 - 79, Машински факултет - Скопје
} 


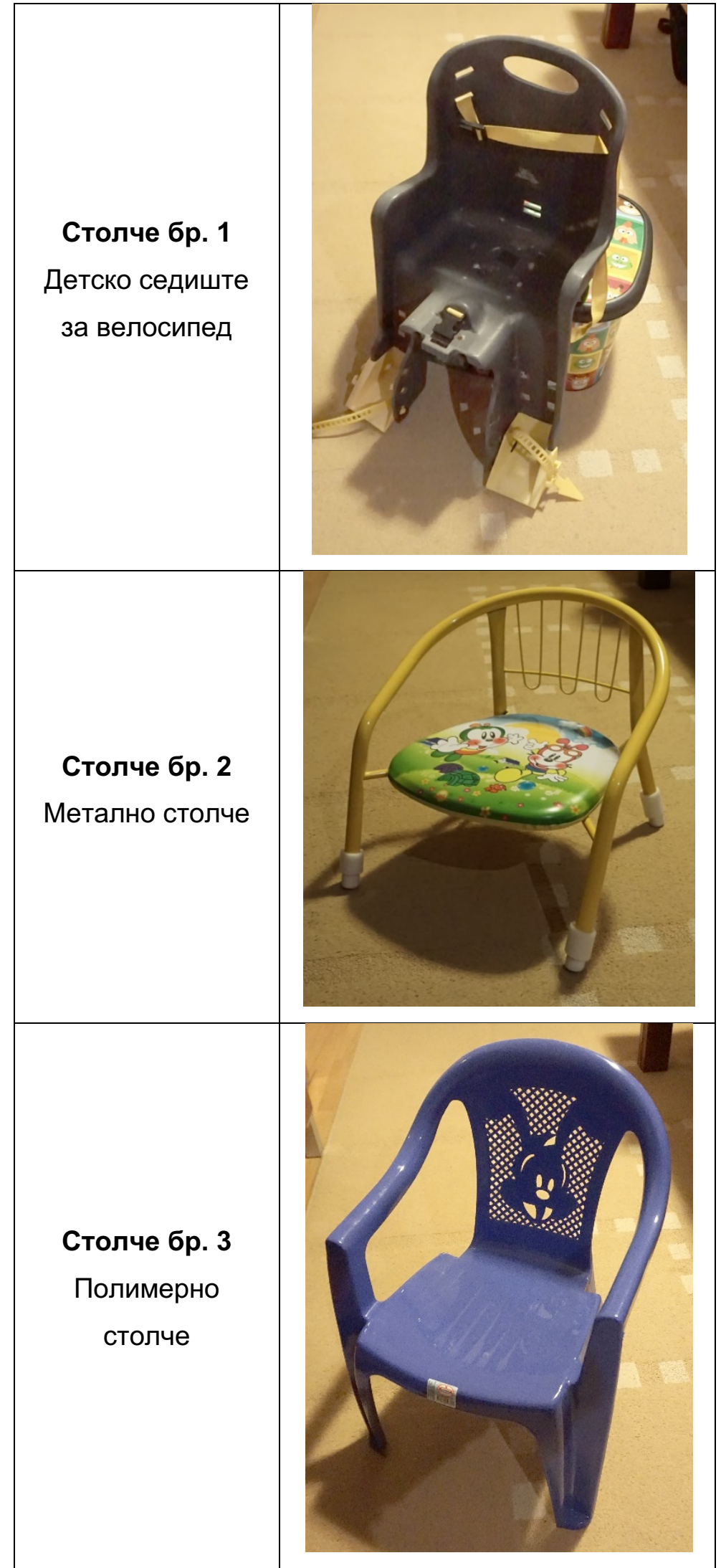

Табела 1 - Трите седишта кои беа предмет на истражувањето 
Во текот на испитувањето беа измерени релевантни параметри кои се потребни во понатамошните фрази на дизајнот на детско седиште:

1. максималниот и просечниот притисок во $\mathrm{mm} \mathrm{Hg}$ (подоцна трансформиран во kPa);

2. површината на седење во $\mathrm{mm}^{2}$.
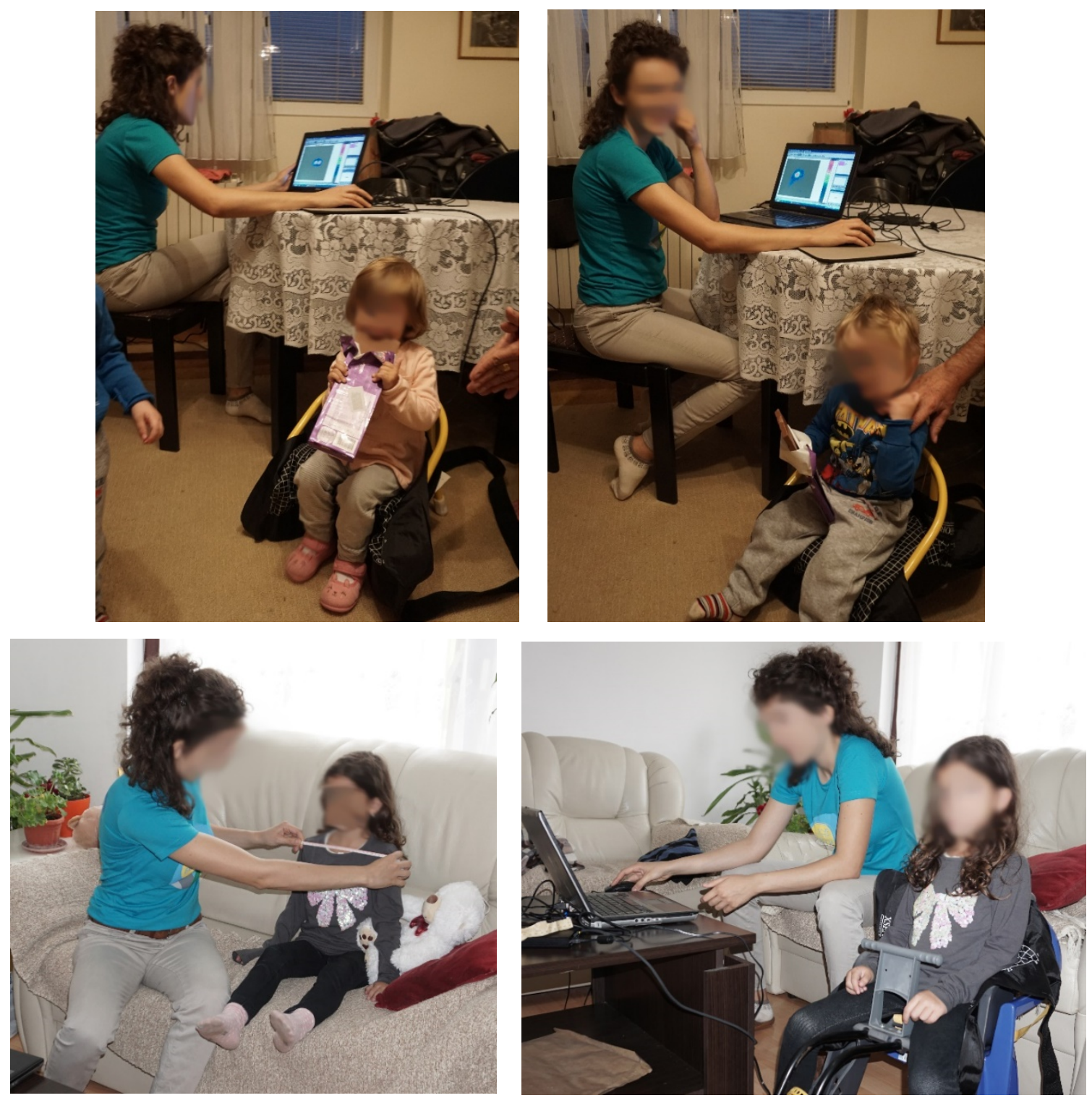

Слики 2-5: Мерење на притисок, површина и земање податоци од децата

Софртверот овозможува визуелизација на резултатите од испитувањето преку дијаграми на распределба на притисоците врз површината на седиштето. Дијаграмот го презентира интензитетот на притисоците со различни бои и нијанси: со црвена боја се прикажани површините со најголеми притисоци, со портокалова површините со нешто послаби притисоци, потоа жолти, светло 
сини, па се до темно сини полиња кои регистрираат области без притисок. Во посебни прозорчиња во розовите табели се испишани вредностите за резултантните среден и максимален притисок, како и површината на седење. Пример за визуелниот приказ на овој дијаграм е слика 6.

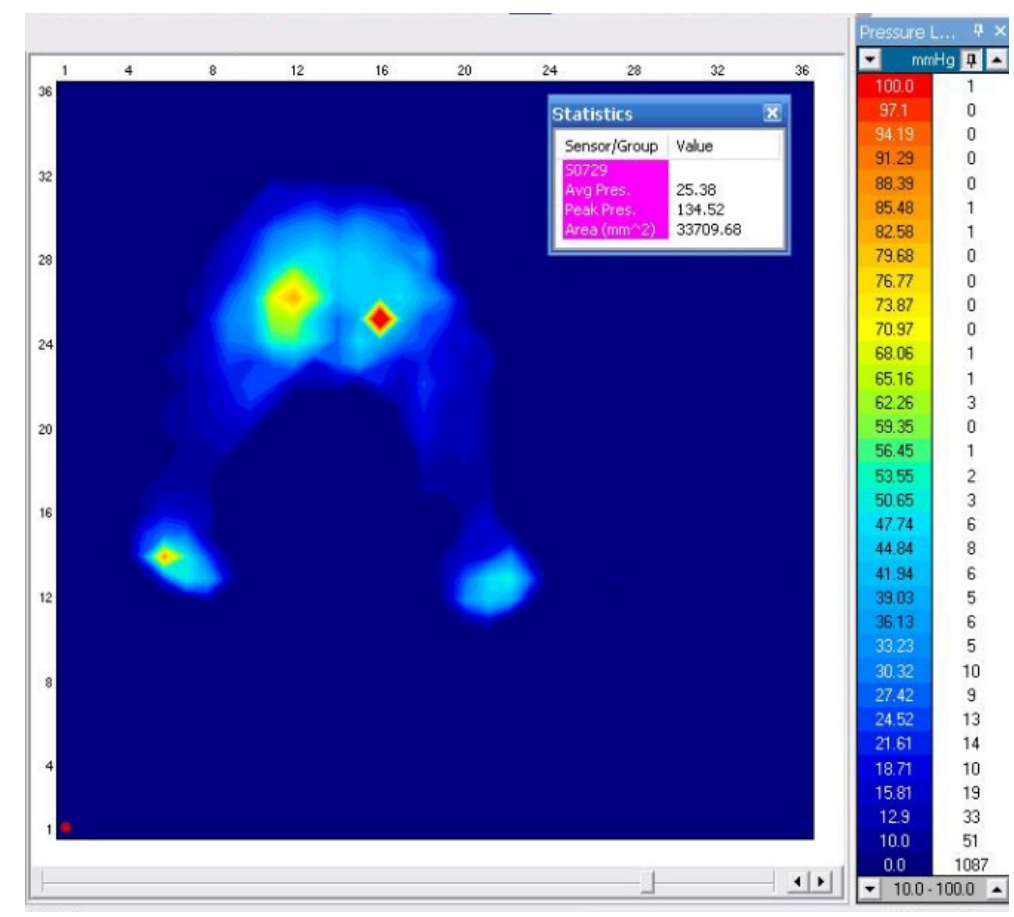

Слика 6: Пример за дијаграм за распределба на притисокот и површината на седење

\section{1 Резултати од испитување на удобноста на столче бр. 1}

Најпрво се разгледани резултатите од столче бр.1, кое е стар модел на детско седиште за велосипед.

Дијаграм 1-10 од испитувањето на столче бр. 1

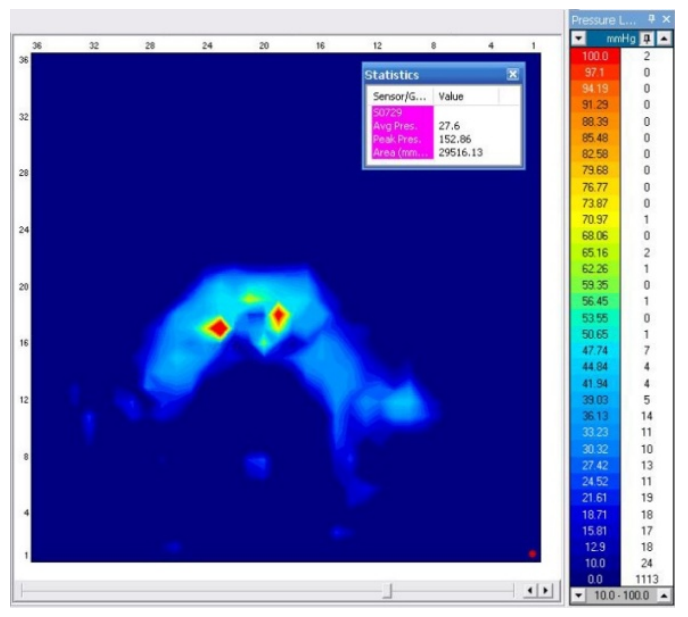

Дете 1

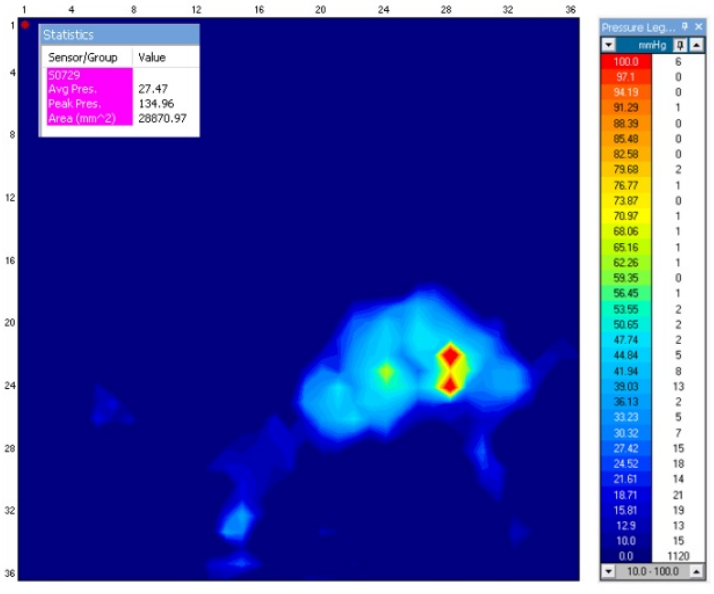

Дете 2 


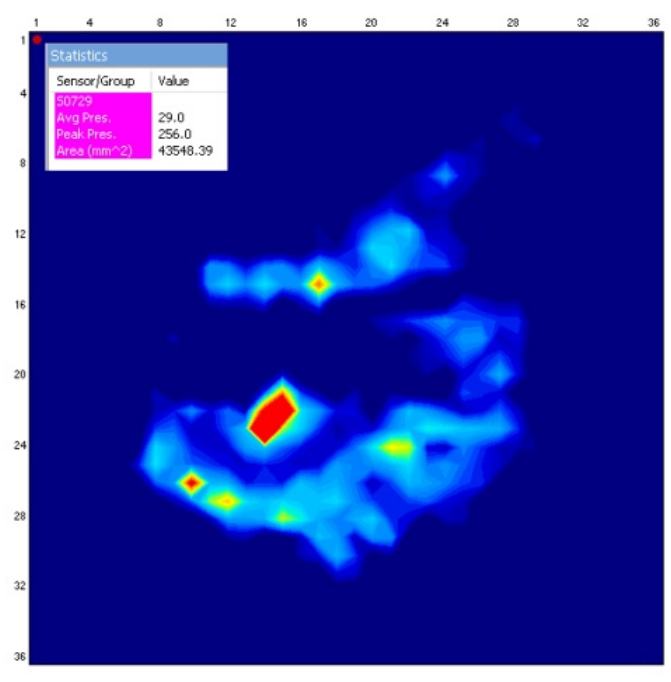

Дете 3

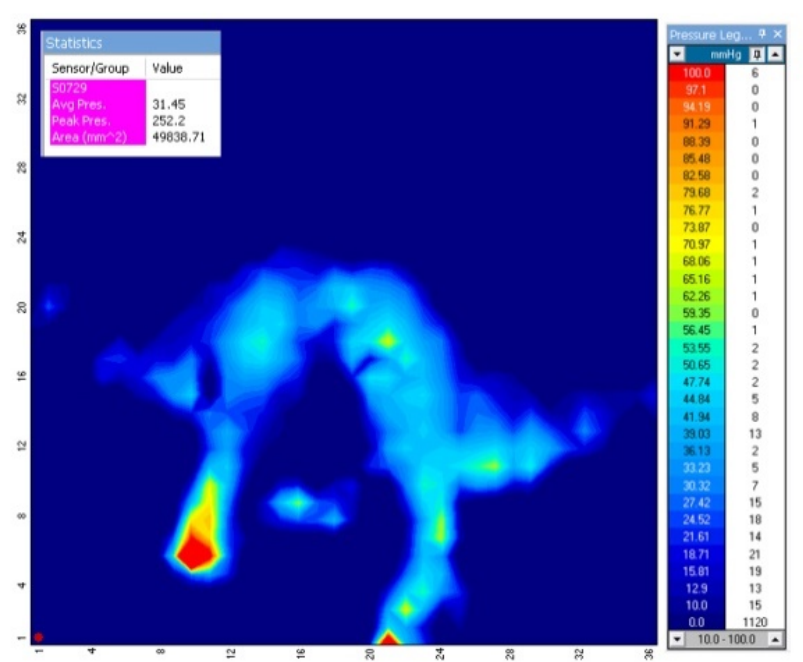

Дете 5

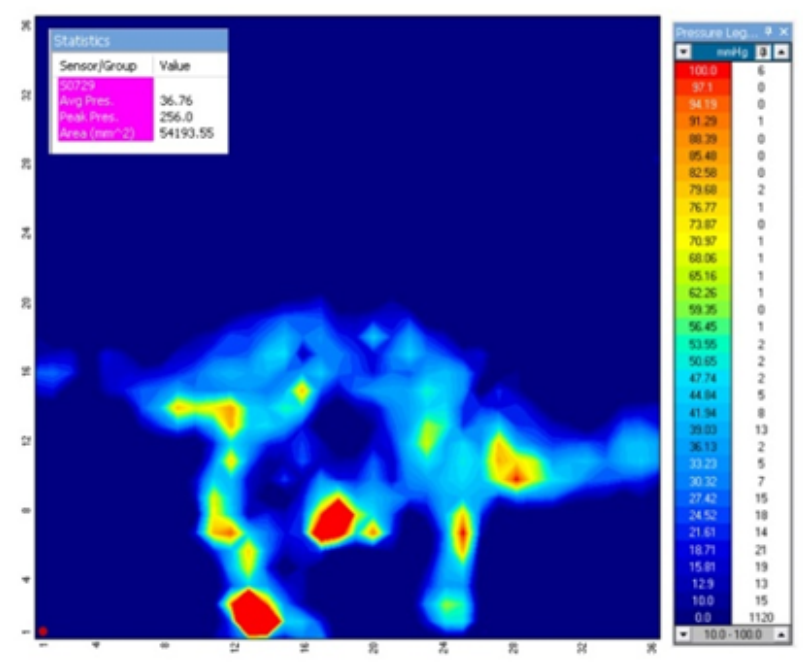

Дете 7

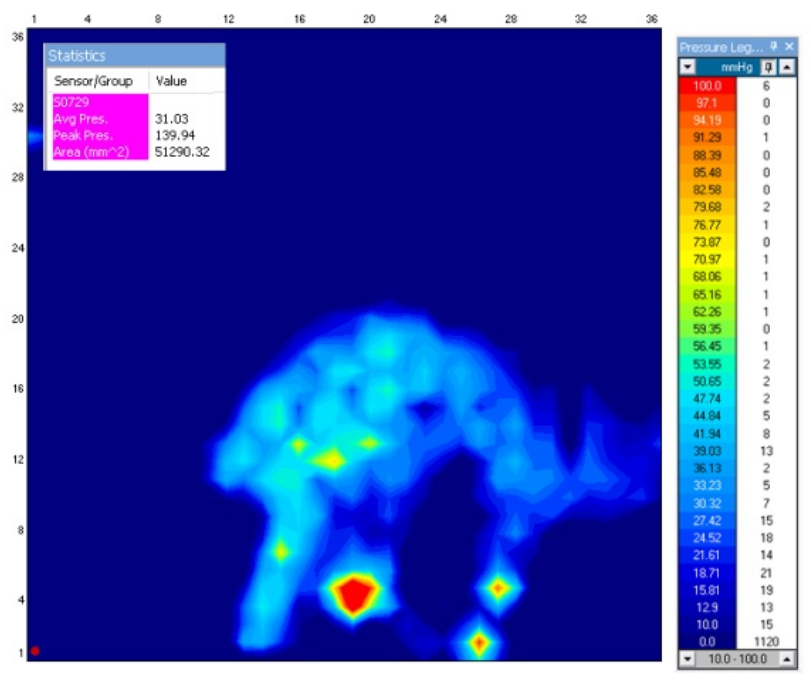

Дете 4

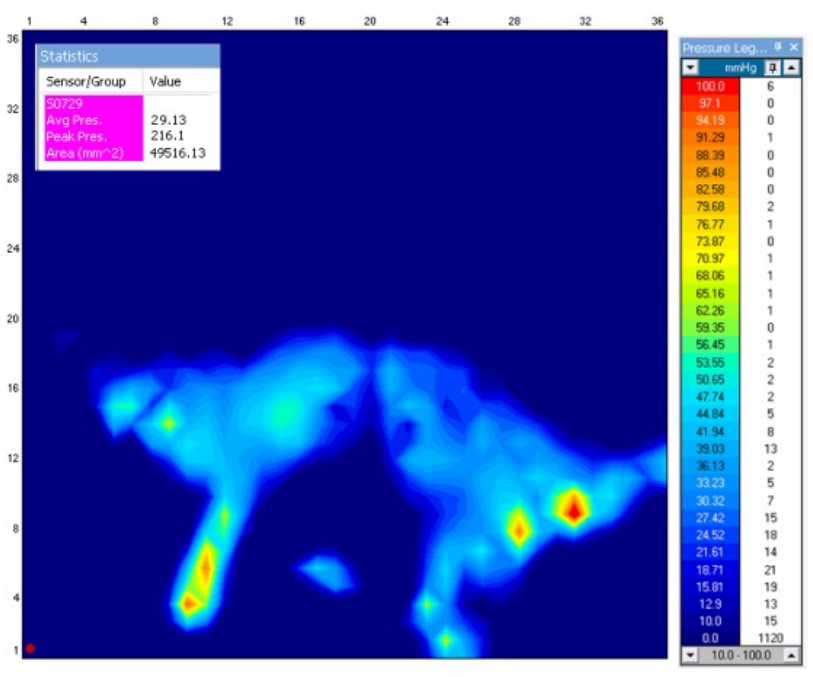

Дете 6

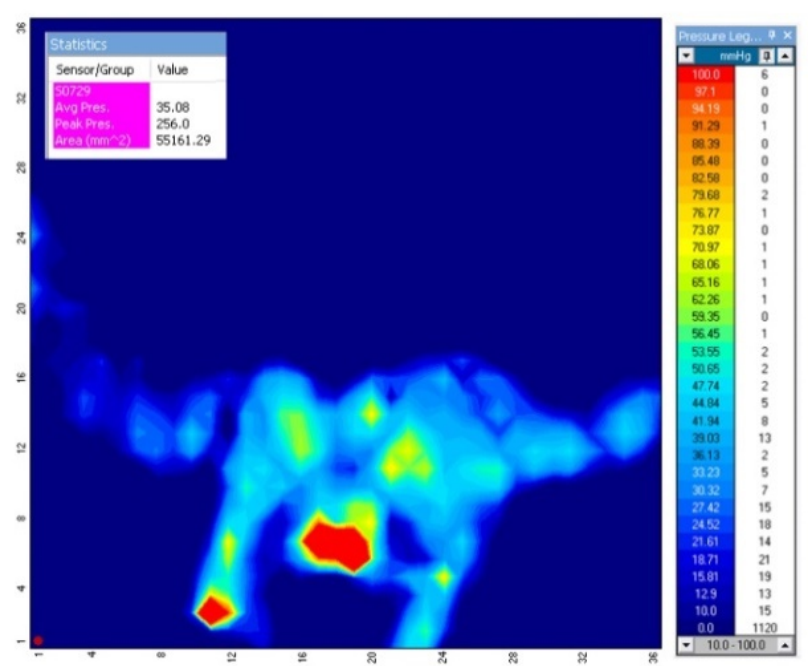

Дете 8 


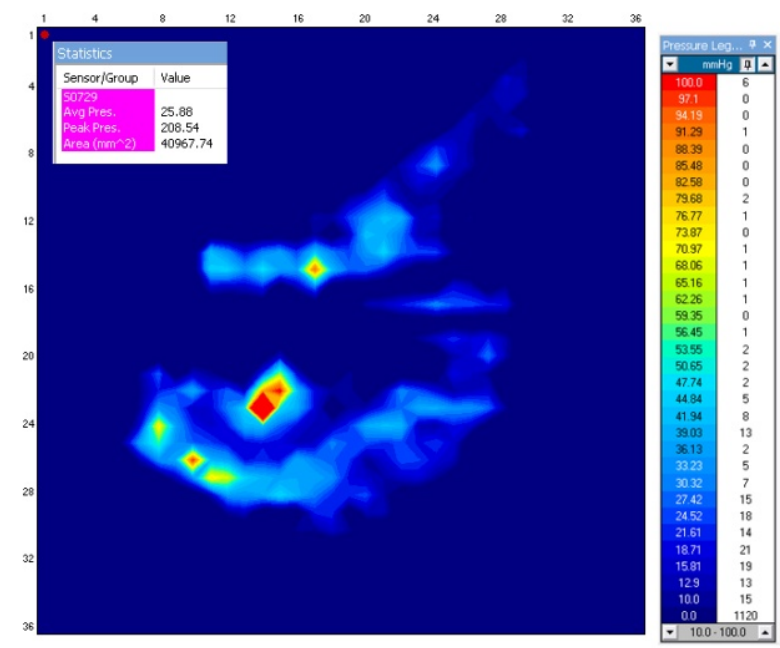

Дете 9

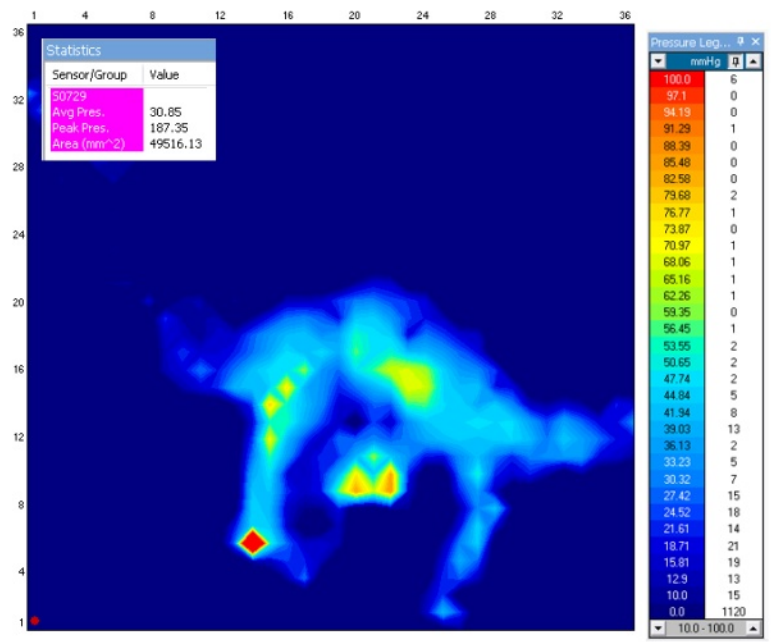

Дете 10

Од дијаграмите лесно може да се воочат големи притисоци, со средни вредности кои се движат во рангот од 3,68 до 4,9 kPa $(27,6$ - 36,76 mm Hg) и максимални од 17,99 до 34,13 kPa (134,96 - $256 \mathrm{~mm} \mathrm{Hg}$ ) на неочекувани места, како и нерамномерна распределба на површината на седење, која има вредности од 28870,97 до 55161,29 mm². Тоа значи дека обликот на седиштето е неудобен и се коси со основните ергономски начела, почнувајќи од аголот на наклон на потпирачот, кој е 90 степени, па се до неговата форма.

\section{2 Резултати од испитување на удобноста на столче бр. 2}

Дијаграм 1-10 од испитувањето на столче бр. 2

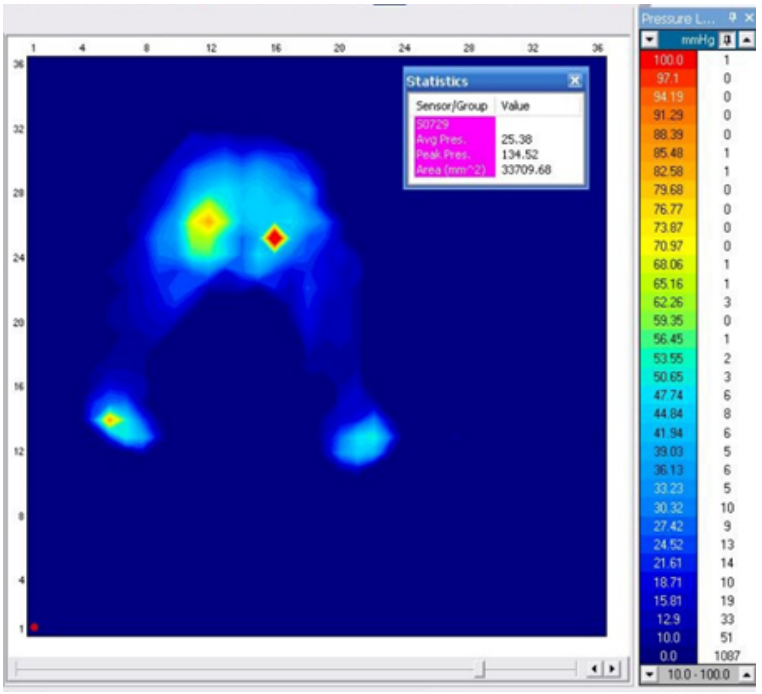

Дете 1

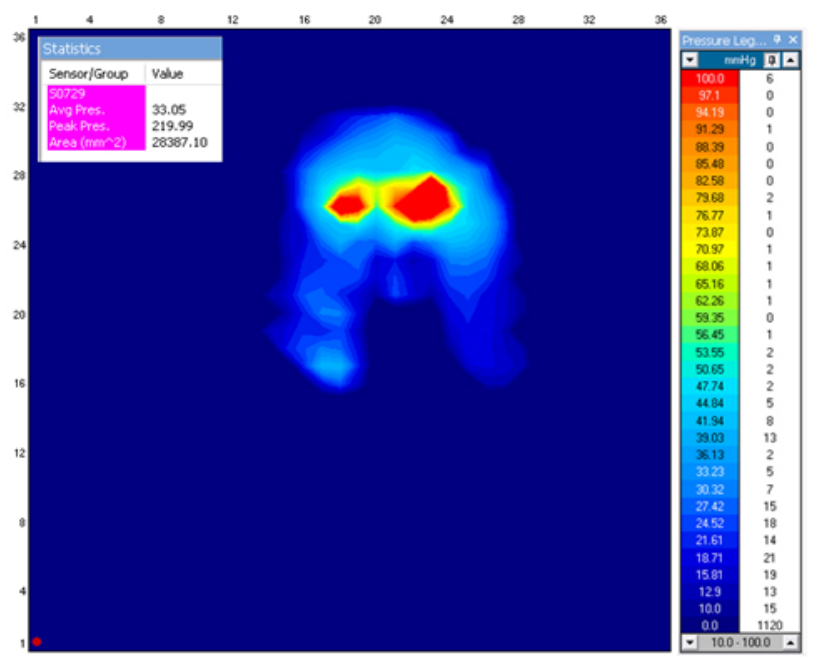

Дете 2 


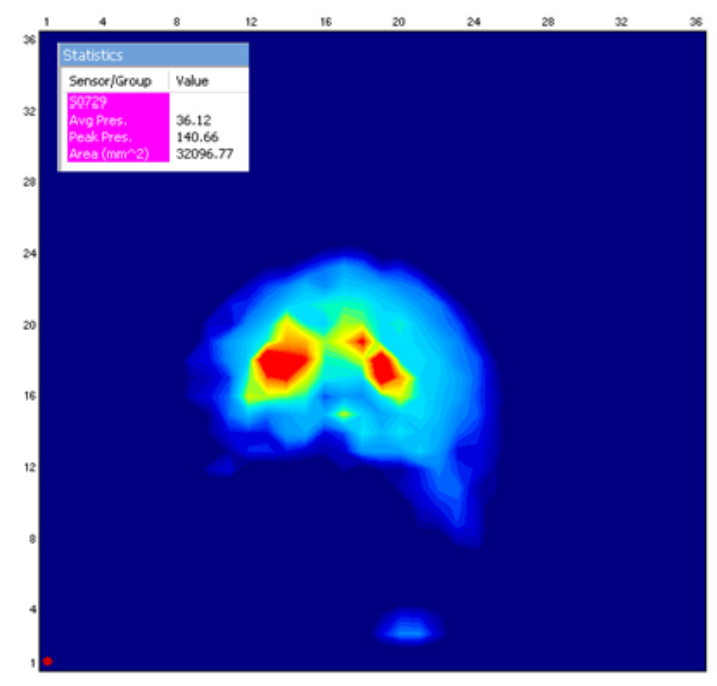

Дете 3

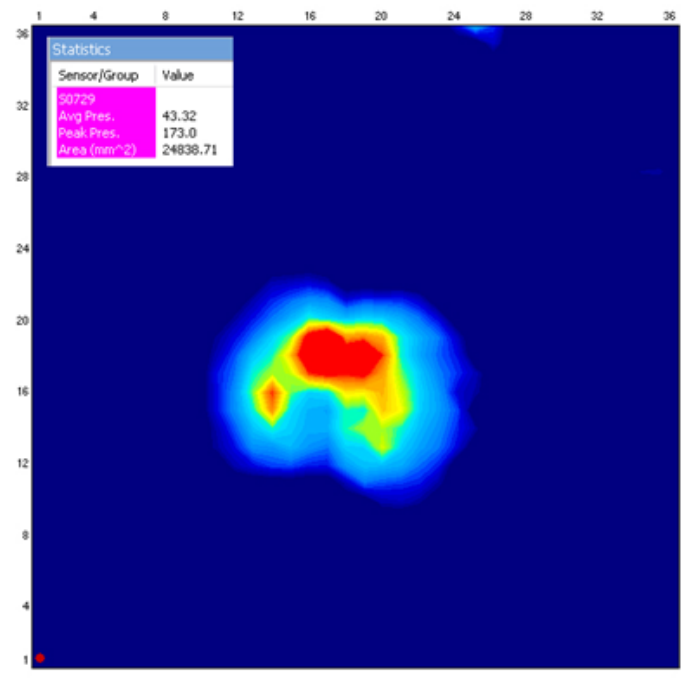

Дете 5

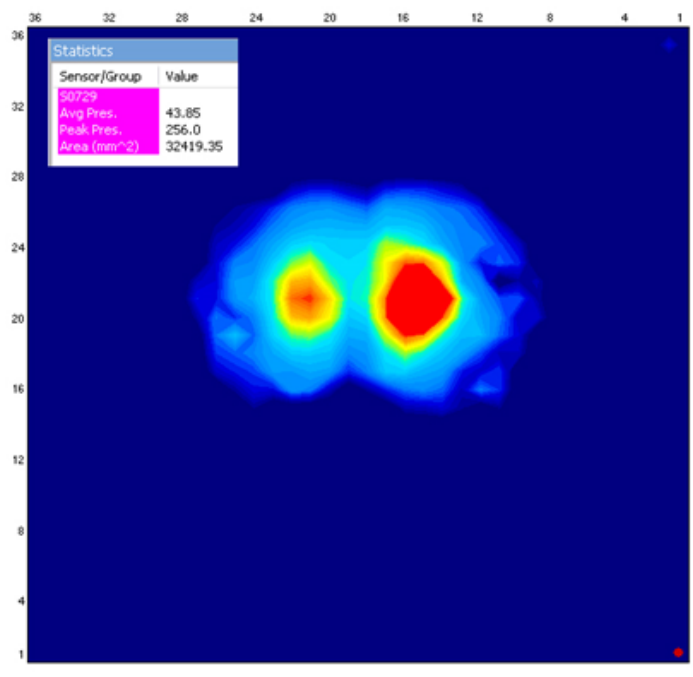

Дете 7
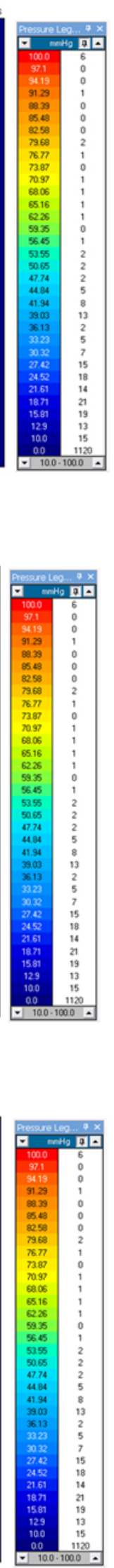

- $100 \cdot 1000$.

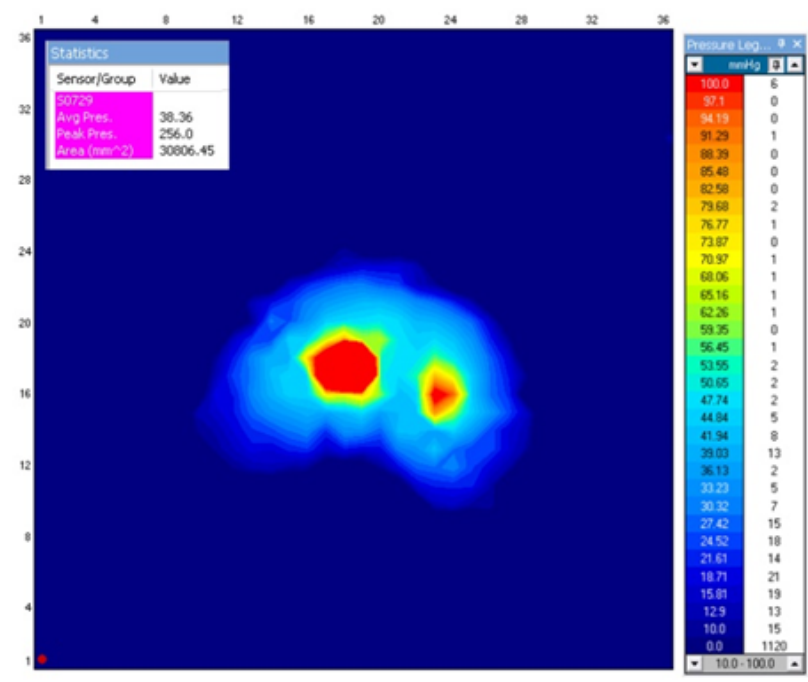

Дете 4

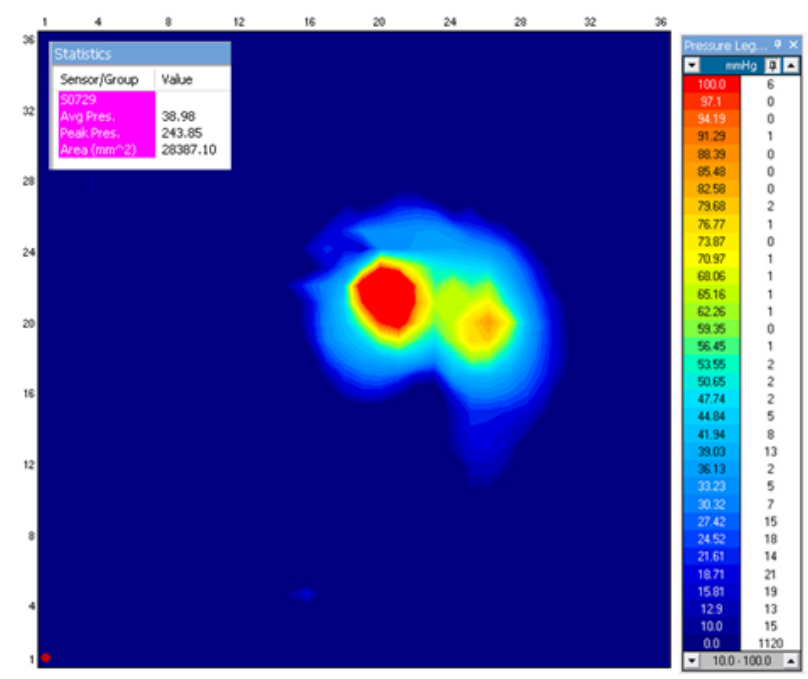

Дете 6

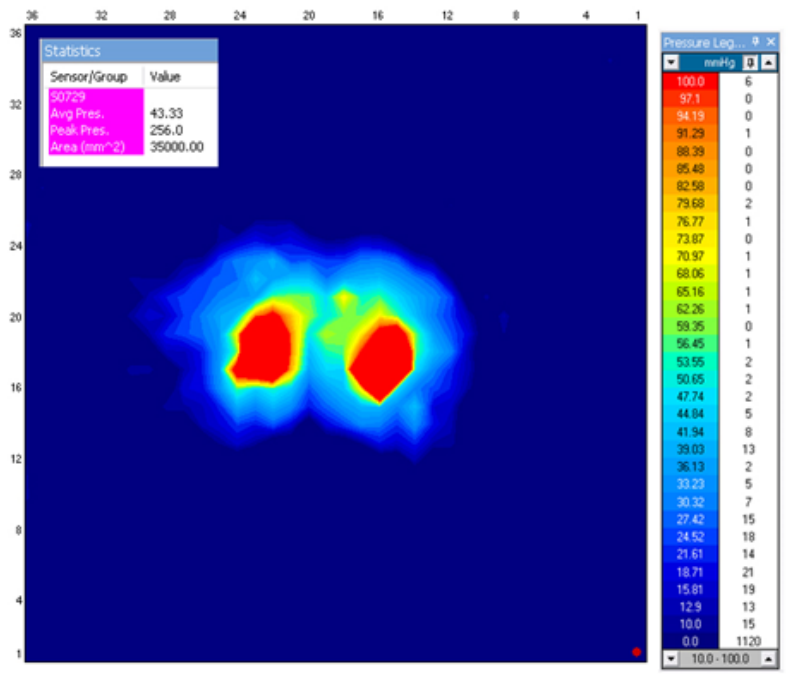

Дете 8 


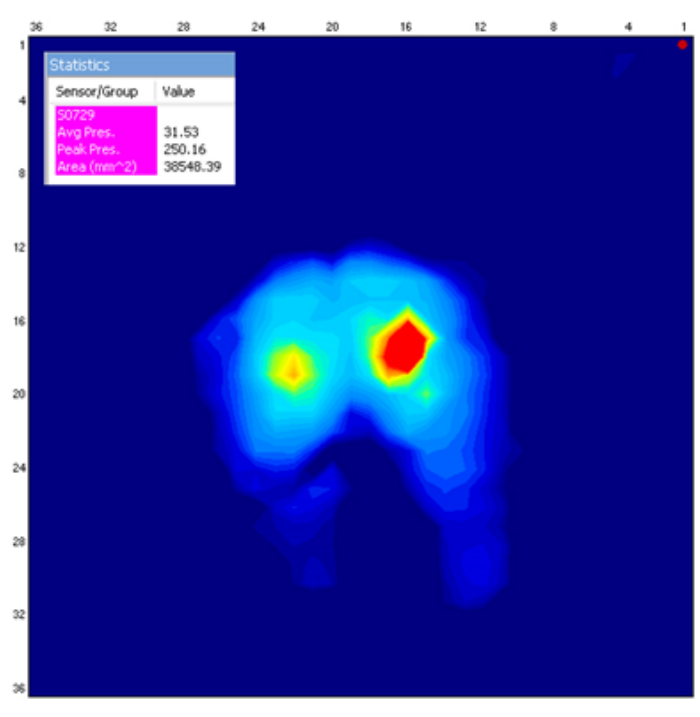

Дете 9

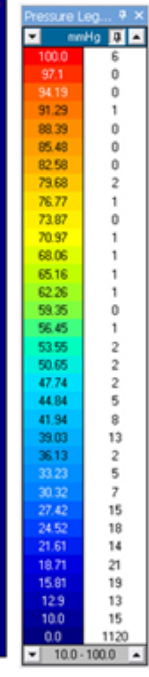

Дете 10

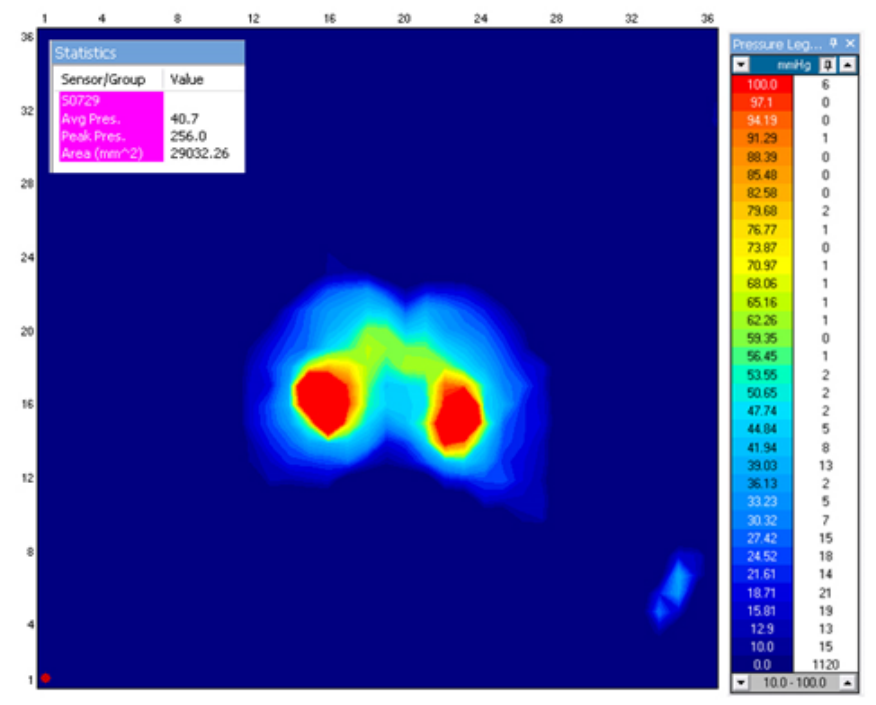

Второто испитано столче беше метално со рамно седиште, обложено со тенок сунѓер. Резултатите од испитувањето на удобноста на ова столче покажаа дека има подобри карактеристики од првото, поради помалите „скокови“ на притисокот. Сепак, седиштето има сосема рамна седална површина, што влијае негативно врз удобноста. Средните вредности на притисоците се движат од 3,38 до $5,85 \mathrm{kPa}(25,38-43,85 \mathrm{~mm} \mathrm{Hg})$, додека максималните се во опсег од 17,93 до $34,13 \mathrm{kPa}(134,52-256 \mathrm{~mm} \mathrm{Hg})$. Тоа е и најниско од сите столчиња во истражувањето, што предизвикува колената да бидат поставени повисоко од карлицата, која е уште една неанатомска положба. Површината на седење е во рангот од 29032,26 до $38548,39 \mathrm{~mm}^{2}$. Истата може да се очекува дека е помала од претходното столче како последица на тоа дека поради повисоко поставените колена децата се приморани да ја одвојат натколеницата од столчето, а со тоа и да ја намалат допирната површина. 


\section{3 Резултати од испитување на удобноста на столче бр. 3}

Третото испитување беше извршено на столче изработено од пластика со инјекционо бризгање во алат. Во продолжение се визуелно претставени добиените резултати.

Дијаграм 1-10 од испитувањето на столче бр. 3

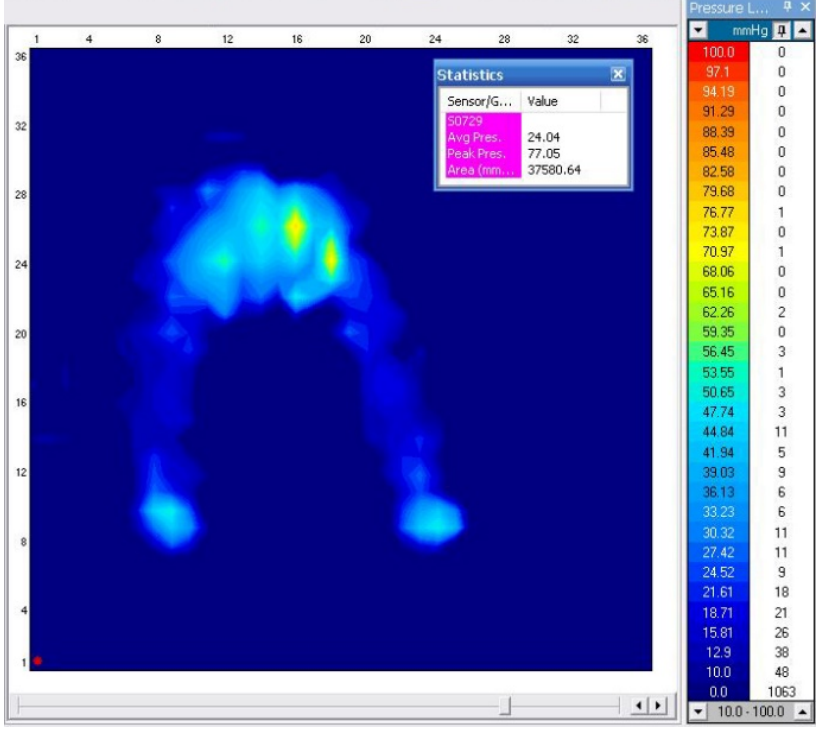

Дете 1

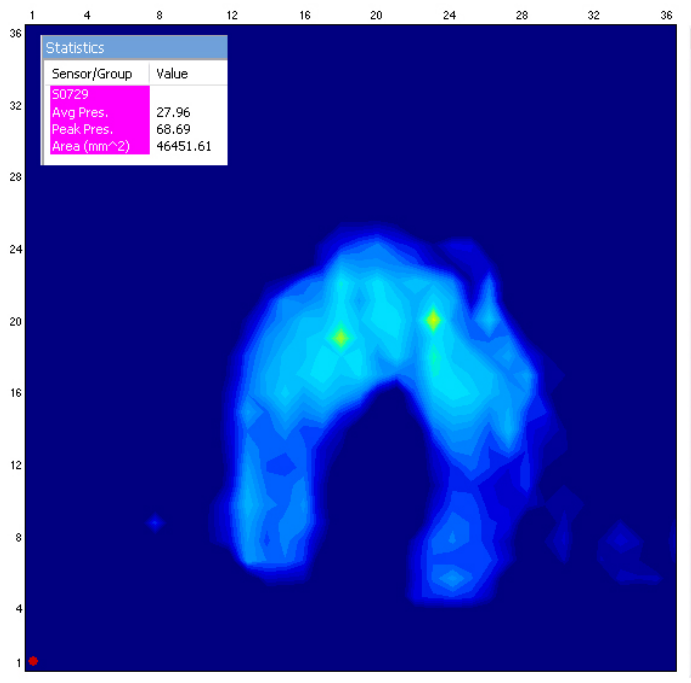

Дете 3

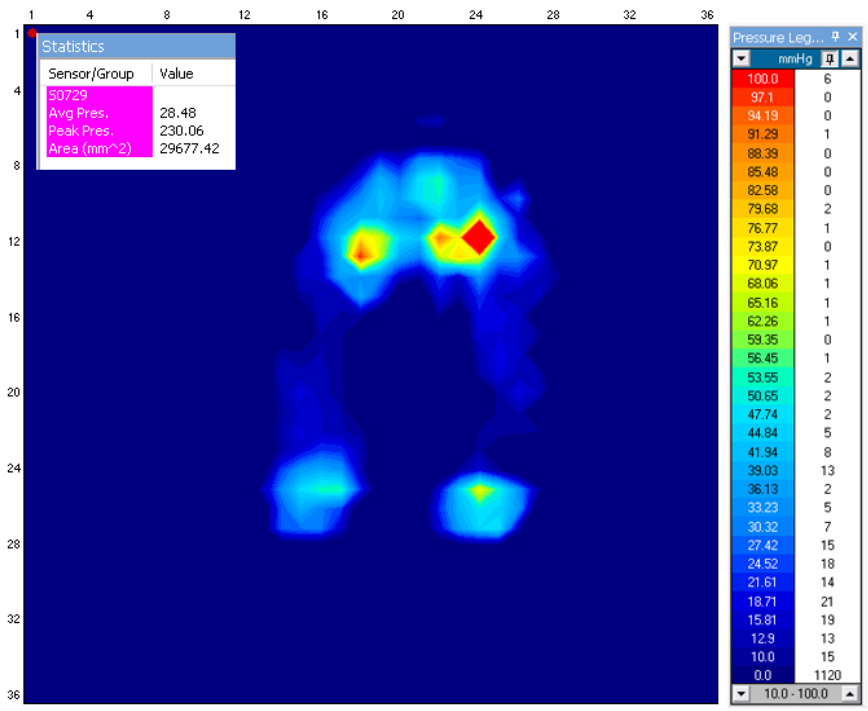

Дете 2

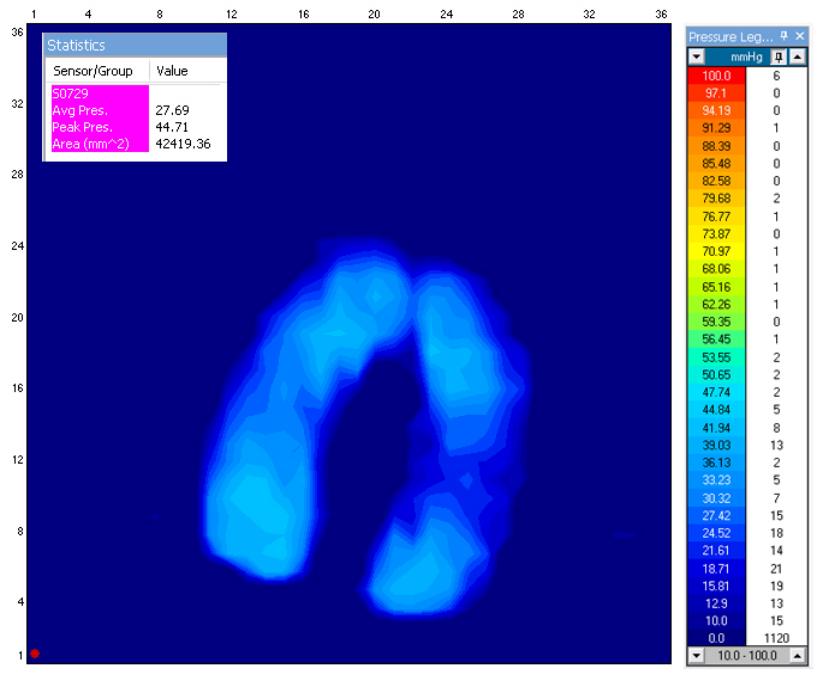

Дете 4 


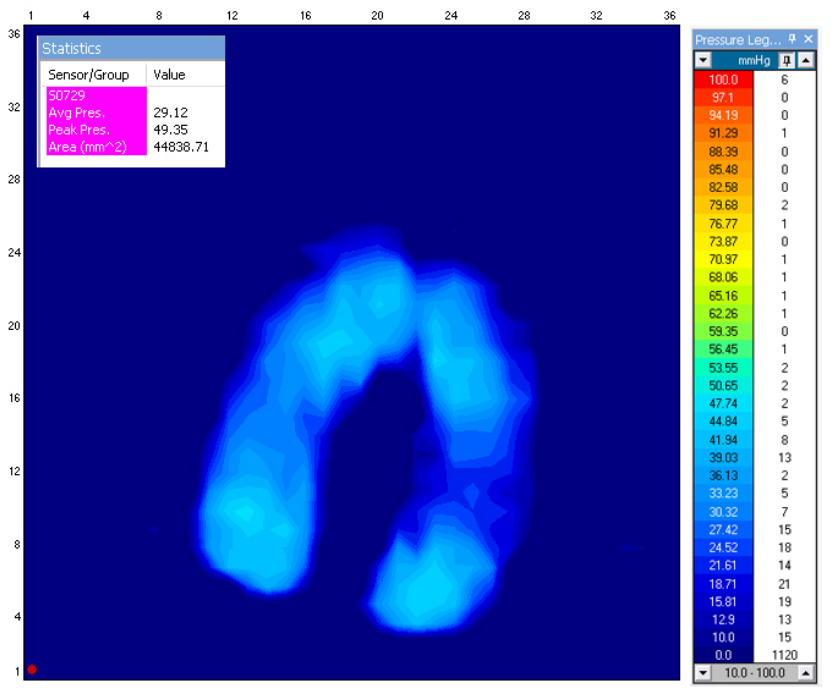

Дете 5

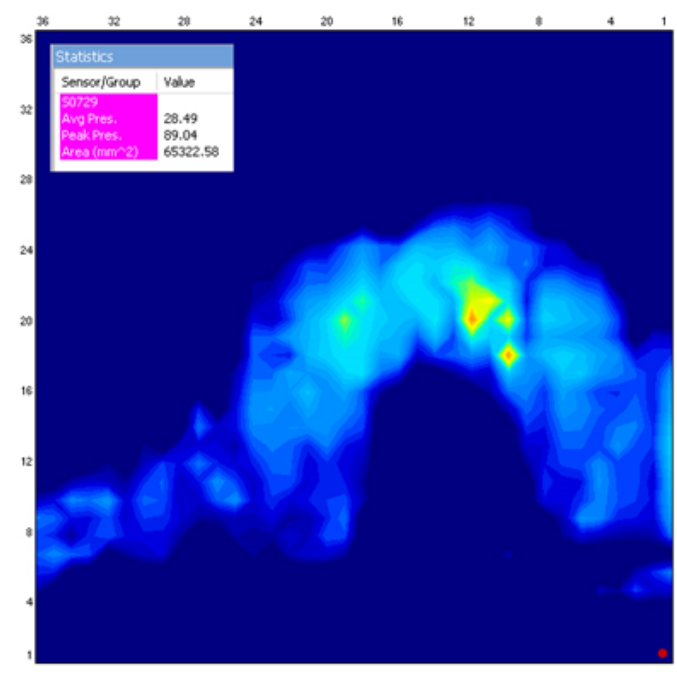

Дете 7

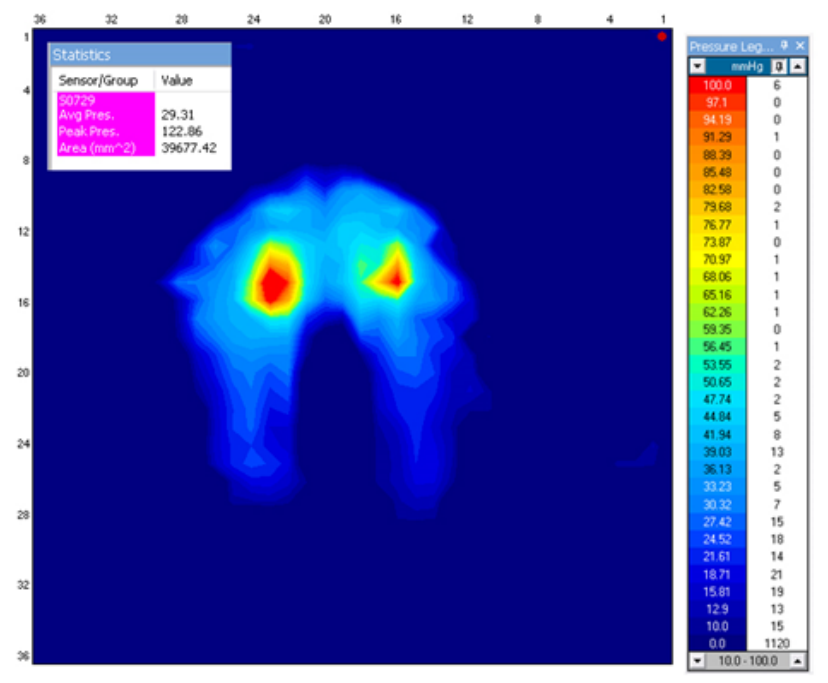

Дете 9

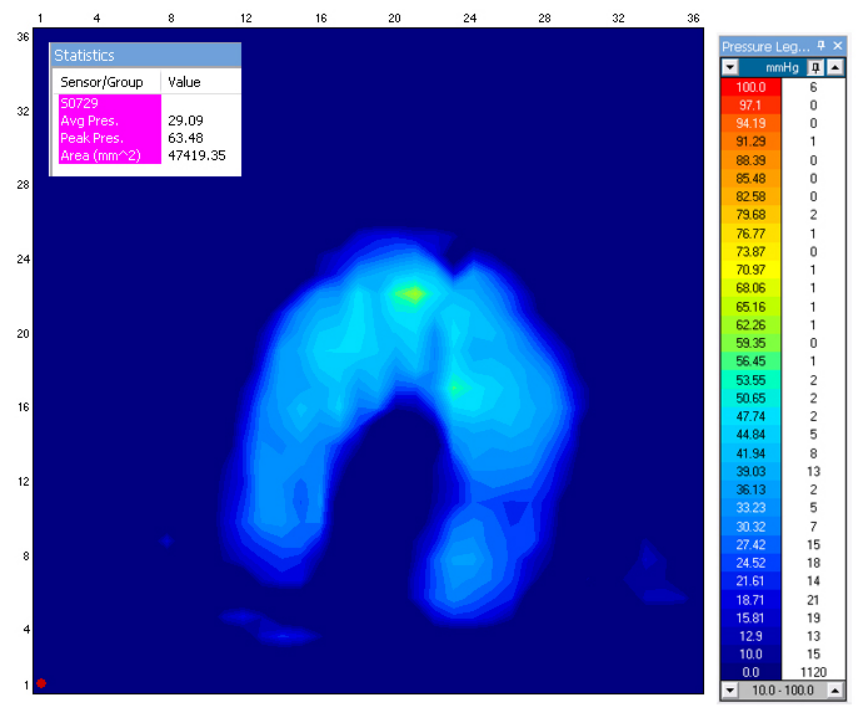

Дете 6

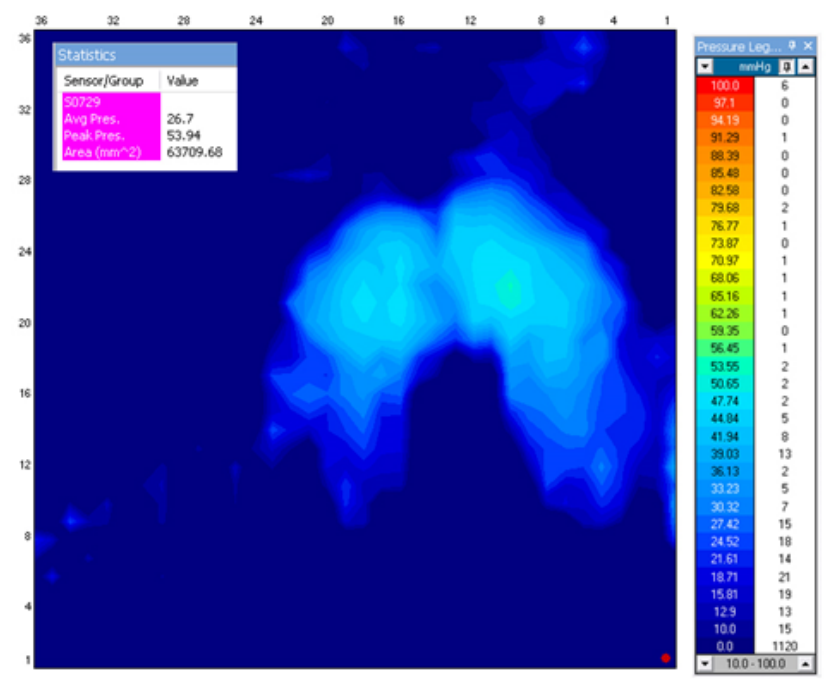

Дете 8

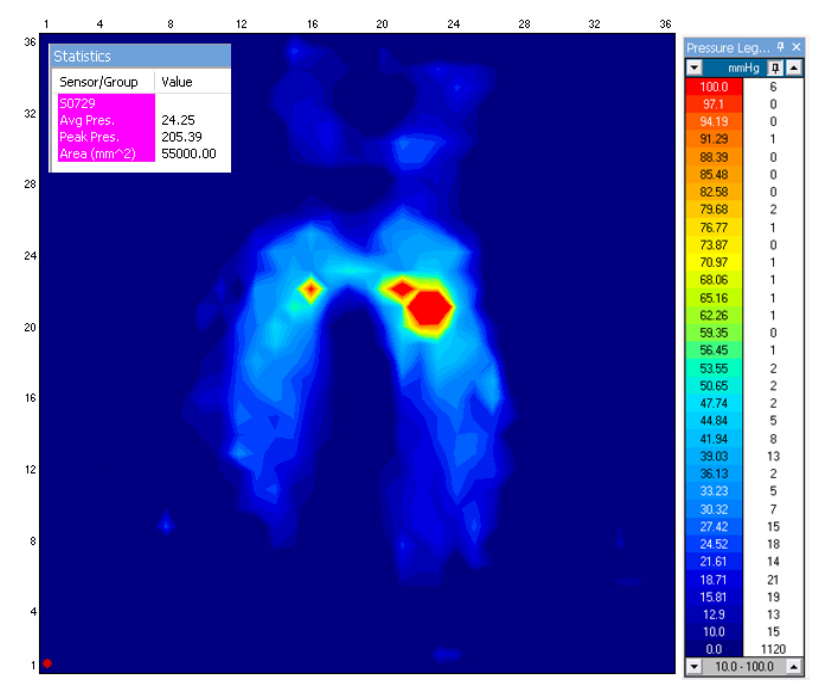

Дете 10 
Веднаш се забележува дека ова седиште е подобро од претходните две од аспект на анатомски облик. Притисоците се многу порамномерно распоредени, има најмалку „скокови“, а тие се со помали вредности и со логичен распоред, во однос на тежиштето кое се наоѓа во карличната коска. Тоа го потврдуваат и податоците. Средните вредности на притисокот се во рангот од 3,21 до $3,92 \mathrm{kPa}(24,04-29,31 \mathrm{~mm} \mathrm{Hg})$, а максималните од 6,58 до $30,67 \mathrm{kPa}(49,35$ - 230,06 mm Hg). Површината е најголема, се движи од 29677,42 до $65322,58 \mathrm{~mm}^{2}$.

\section{4 Извлечени заклучоци од извршените ергономски}

\section{испитувања}

Како краен заклучок од оваа ергономска анализа, може да се потврди дека од трите понудени варијанти, столче бр.3 би било најдобар урнек за удобно седење. Останатите негови карактеристики се: агол на наклон на потпирачот од 110 степени, мала конкавност (вдлабнатост) на површината за седење и полипропиленска основа (конструкција).

Секако дека ова столче понатаму ќе служи како основа за развојот на моето детско седиште за велосипед, во поглед на обликот на седиштето и потпирачот. За разлика од него, другите столчиња имаат агол на наклон од 90 степени и сосема рамна површина на седиштето. Столче бр. 1 имаше и додатен дел меѓу нозете, кој дополнително ја намалува удобноста на седење.

Дизајнот на столче бр. 3 е подобар и заради фрормата од аспект на безбедност и стабилност, поради тоа што тежиштето на детето е сместено во најнискиот дел од седлото, со што околниот материјал кој е малку повисок, го заштитува како во лулка. Поради истата причина е многу помала и веројатноста столчето да се преврти. Ова е особено важен аспект кој сакам да биде особено нагласен во дизајнот на моето седиште. 


\section{8 Извлекување инспирација за решавање на одделните зададени цели}

Со цел да се најде најсоодветно решение за зададените цели неопходна е инспирација. За дизајнерите кои ги познаваат бионичките принципи и стратегии тоа значи да трагаат во огромниот океан на решенија од природата. Револуционерна идеја за нов производ може да се иницира со примена на стратегијата од решение од природата кон решавање на дизајнерски или инженерски проблем. Стратегијата од дизајнерски проблем кон потрага по решение во природата обезбедува совладување на сложени проблеми според урнек од генијалната природа.

\section{1 Пресормулирање на дизајнерските барања}

Првиот чекор во фазата на извлекување инспирација од природата беше преформулирање на дефинираните дизајнерски барања со цел да бидат споредливи со описите на препознаени феномени од природата.

Чинот на инспирирање се состои во пронаоѓање на сличности - врски помеѓу дизајнерските барања и решенијата од природата, односно откривање кои корисни карактеристики од природните решенија можат да се искористат во оптимизирање на производот. Тие се претставени во следните две табели.

\begin{tabular}{|l|l|}
\hline \multicolumn{1}{|c|}{ Дизајнерски барања } & \multicolumn{1}{|c|}{ Начини на реализација } \\
\hline 1) Компактност & Фрактален дизајн \\
\hline 2) Преносливост & Оптимизрање на облик \\
\hline 3) Мала маса (до 2,1 кг.) & Материјали \\
\hline 4) Лесна монтажа (5 сек.) & Оптимизрање на облик \\
\hline 5) Поделба на просторот за седење & Фрактален дизајн \\
\hline 6) Носивост (22 кг.) & Технологија, материјали \\
\hline 7) Безбедност & Сигурносен појас, облик \\
\hline 8) Повеќе функции & Оптимизирање на облик \\
\hline 9) Механизам за ротација & Топчест зглоб \\
\hline 10) Цена до 110 & Економичност на ресурси \\
\hline
\end{tabular}




\begin{tabular}{|l|l|}
\hline 11)Естетика, привлечен дизајн & Облик, форми, бои, линии \\
\hline 12)Трајност (мин. 5 год.) & Материјали \\
\hline 13)Лесна видливост & Површинска обработка, боја \\
\hline
\end{tabular}

Табела 1 - Инженерските барања и можни начини на нивна реализација

\begin{tabular}{|ll|}
\hline Решенија од природата & Реформулација на решенијата во однос на барања \\
\hline Фрактален дизајн & Проблем на прилагодување на големините, \\
& поделба на просторот, компактност \\
\hline Биолуминисценција & Лесна видливост во темнина \\
\hline
\end{tabular}

Табела 2 - Преформулирање на решенијата

\section{2 Изнаоѓaње соодветност помеѓу инженерските проблеми и решенија понудени од природата}

\begin{tabular}{|c|c|}
\hline Чекор & Опис \\
\hline $\begin{array}{l}\text { В1: Избор на } \\
\text { решенија } \\
\text { од природата }\end{array}$ & $\begin{array}{l}\text { - Набљудување на природните феномени и } \\
\text { идентификација на потенцијалните решенија или } \\
\text { биолошки својства со натпросечни } \\
\text { карактеристики, кои имаат потенцијал за примена } \\
\text { кај човечките проблеми. }\end{array}$ \\
\hline $\begin{array}{l}\text { В2: Анализа на } \\
\text { решенијата }\end{array}$ & $\begin{array}{l}\text { - Идентификација и морфолошка анализа на } \\
\text { структури, компоненти, процеси и функции на } \\
\text { биолошкото решение. } \\
\text { - Екстракција на фундаменталните принципи кои } \\
\text { го мотивираат решението. }\end{array}$ \\
\hline
\end{tabular}




\begin{tabular}{|c|c|}
\hline $\begin{array}{l}\text { В3: Реформулација } \\
\text { на решението }\end{array}$ & $\begin{array}{l}\text { - Посветеност на генералните принципи, добиени } \\
\text { во претходниот чекор, подетално разгледување } \\
\text { на можните врски меѓу биолошкото и механичкото } \\
\text { однесување. }\end{array}$ \\
\hline $\begin{array}{l}\text { В4: Барање на } \\
\text { инженерски }\end{array}$ & $\begin{array}{l}\text { - Со помош на податоците добиени во } \\
\text { претходниот чекор, наоѓање на решенија кои } \\
\text { треба да се оптимизираат или нови потреби кои } \\
\text { можат да бидат задоволени со земање во } \\
\text { предвид на бионичките идеи кои се } \\
\text { идентификувани. }\end{array}$ \\
\hline $\begin{array}{l}\text { В5: Информации за } \\
\text { дизајнот и } \\
\text { асоцијациски } \\
\text { принципи }\end{array}$ & $\begin{array}{l}\text { - Спецификација на проблемот што треба да се } \\
\text { реши со идентификување на функциите кои тој } \\
\text { мора да ги извршува, посакуваните барања и } \\
\text { органичувања, како и еколошките аспекти } \\
\text { поврзани со својствата извадени од анализата на } \\
\text { бионичкото решение. }\end{array}$ \\
\hline $\begin{array}{l}\text { C1: Генерирање на } \\
\text { концепти }\end{array}$ & $\begin{array}{l}\text { - Развој на идеи и концепти (во форма на скици и } \\
\text { 3D модели) и следење на насоките и принципите } \\
\text { усвоени во чекорите на анализа и дефинирање на } \\
\text { биолошкото решение за проблемот. }\end{array}$ \\
\hline С2: Потврдување & $\begin{array}{l}\text { - Верификација на усогласеноста на врската меѓу } \\
\text { барањата од проблемот и придобивките воведени } \\
\text { преку бионичкиот концепт, за да се постигнат } \\
\text { целите кои се поставени. } \\
\text {-Избор на најсоодветен концепт за следниот чекор }\end{array}$ \\
\hline $\begin{array}{l}\text { С3: Детали и } \\
\text { завршна обработка }\end{array}$ & $\begin{array}{l}\text { - Изработка на технички цртежи за производство, } \\
\text { детални описи на компоненти, материјали, и сите } \\
\text { разгледувања соодветни на видот и намената на } \\
\text { проектот. } \\
\text { - Макета и презентација на резултатите. }\end{array}$ \\
\hline
\end{tabular}

Табела 3 - Сумаризиран опис на фазите на бионичката методологија развиена со следење на ориентацијата од бионичко решение кон дизајн проблем (В) 


\section{3 Подетална анализа на селектираните решенијата од}

природата

\subsection{1 Фрактали}

Фракталите се шеми базирани на принципот на само-сличност, кои се појауваат насекаде во биологијата и природата. Терминот „фррактал“ бил за првпат употребен од математичарот Benoit Mandelbrot во 1975 година, a ce искористил за да се прошири концептот на теоретските фррактални димензии низ геометриските шеми во природата.
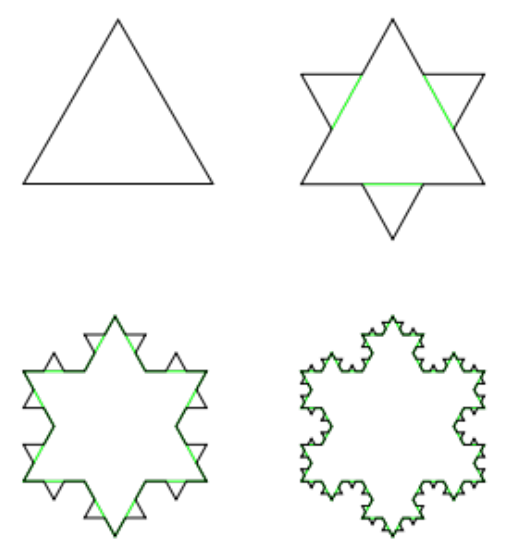

Слика 1 - Првите 4 итерации на снегулката на Koch

Mandelbrot проучувал еден математички проблем, познат како Сетот на Џулиа. Тој сет се состоел од броеви кои биле резултати на определена равенка, така што секој добиен резултат се враќал назад како почетна вредност на равенката. Овој нов вид на математика морал да почека се до развивањето на новата технологија на брзи компјутери. - да ја врати добиената вредност во равенката милиони пати.

Во 1980 г. тој го претставил множеството од броеви графички на компјутер и набрзо станал познат како амблемот на фракталната геометрија. Сега луѓето можеле да видат нешто што дотогаш било невидливо. 


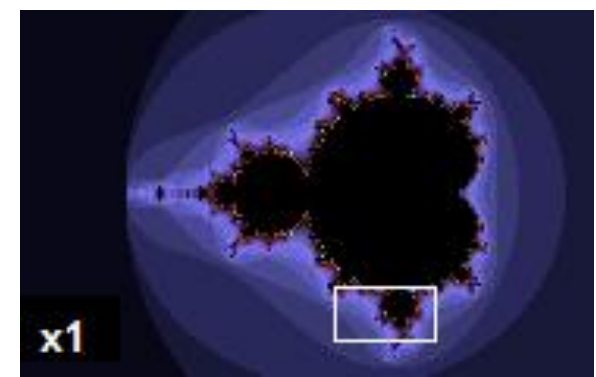

Слика 2 - Сетот на Mandelbrot: Само сличност илустрирана со зголемување на сликата. На оваа слика- размер 1:1

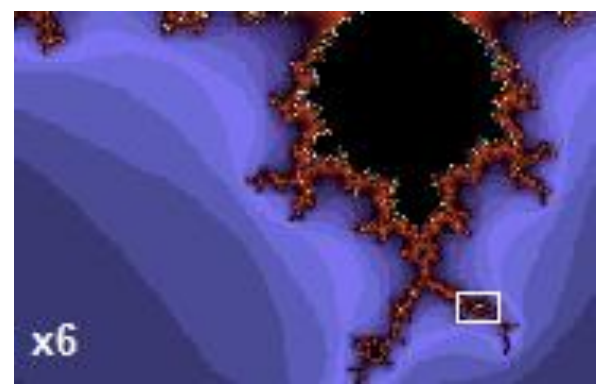

Слика 3 - Истиот фрактал како погоре, зголемен 6 пати. Некои од шемите се повторуваат, што ја отежнува идентификацијата на размерот.

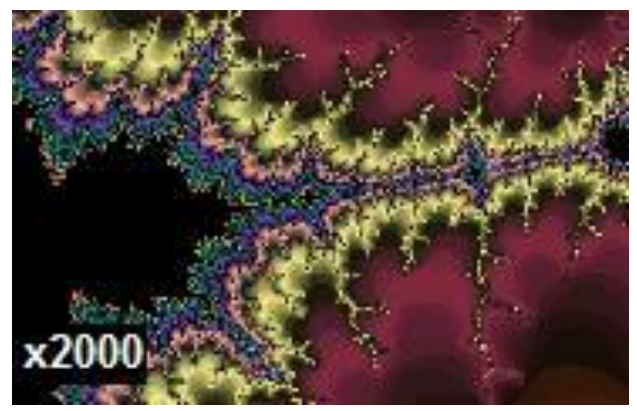

Слика 4 - Истиот фрактал, зголемен 2000 пати, фрините детали на сетот личат пак на деталите од размерот 1:1.

Интересен случај на примена на фрракталите во архитектурата е оној со цртање на слики на sид кој служел за намалување на бучавата во градовите. Тој бил поставен пред дрворед, насаден плански во градот. Sидот бил составен од иденични правоаголни панели. Тезата била дека сцената би изгледала подобро ако фрракталните мерки на ширината и висината на панелите би одговарала на фракталната мерка на силуетите на дрвата во позадина. ${ }^{13}$

${ }^{13}$ Fractals, skylines, nature and beauty- Arthur E. Stamps Institute of Environmental Quality, 290 Rutledge Street, San Francisco, CA 94110, USAReceived 26 March 2002 
Подоцна, инженерската заедница открила дека компјутерската симулација на еволуцијата на Дарвин, која е наречена генетски алгоритам, е многу ефективна за оптимизирање на електронски уреди. ${ }^{14}$
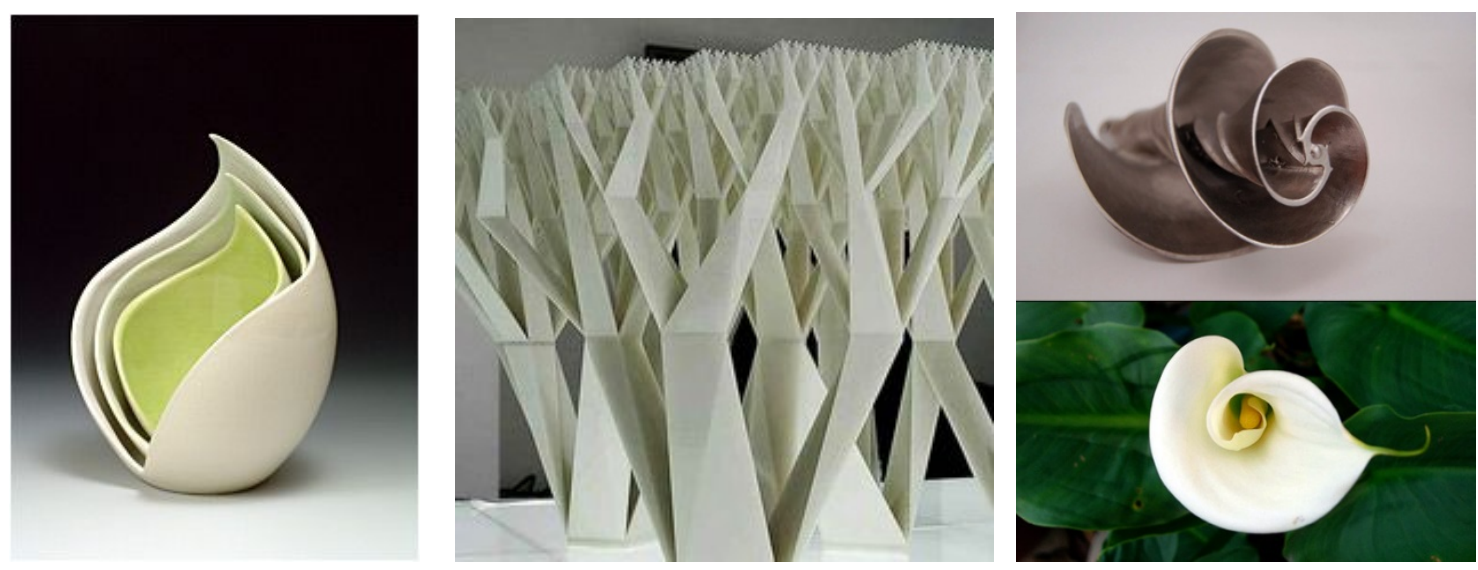

Слики 5-7 - Примена на фрракталите во индустрискиот дизајн
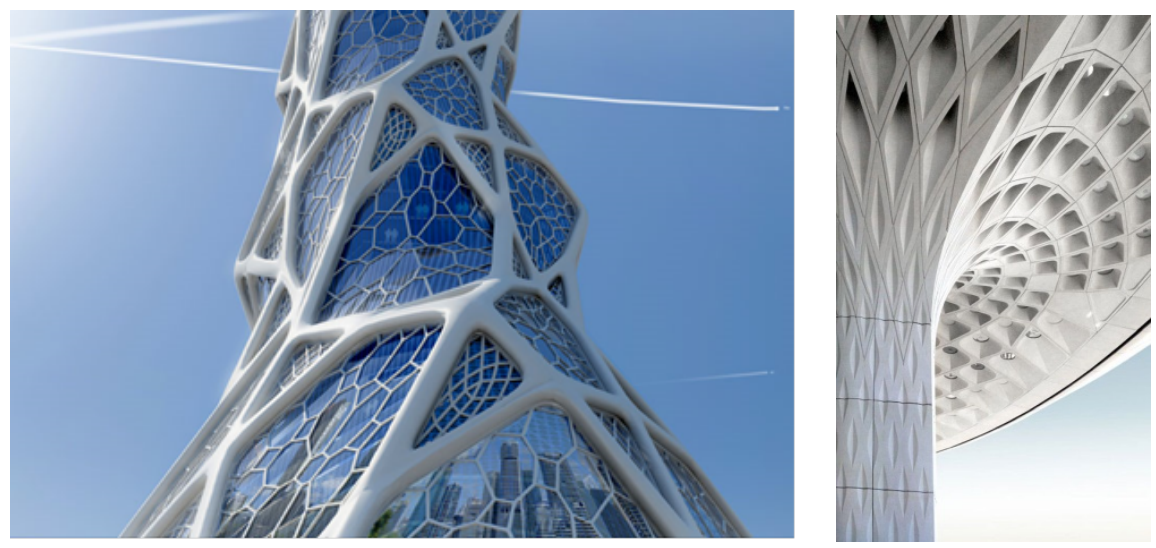

Слики 8 и 9 - Фракталите во архитектурата (бионичката кула и аеродромот во Мумбаи)

Целата органска природа, е одржлива со помош на оние внатрешни мрежи кои пренесуваат кислород, метаболити, и хранливи материи кои ги хранат клетките. Циркулаторниот, нервниот и респираторниот систем се само некои очигледни примери за фракталите во биологијата. А ако овие био-мрежи се фрактални, тоа значи дека се потчинуваат на некои едноставни математички правила, што може да води до нови откритија за нивниот начин на работа. Би било многу неефикасно да се има различен, посебен код за секоја фаза на

${ }^{14}$ Does God play dice? Insights from the fractal geometry of nature - Paul H. Carr Zygon, vol 39, no.4 December 2004 
растење на растенијата. Со фракталите, крајно едноставен генетски код може да произведе нешто што наизглед личи на комплициран организам.
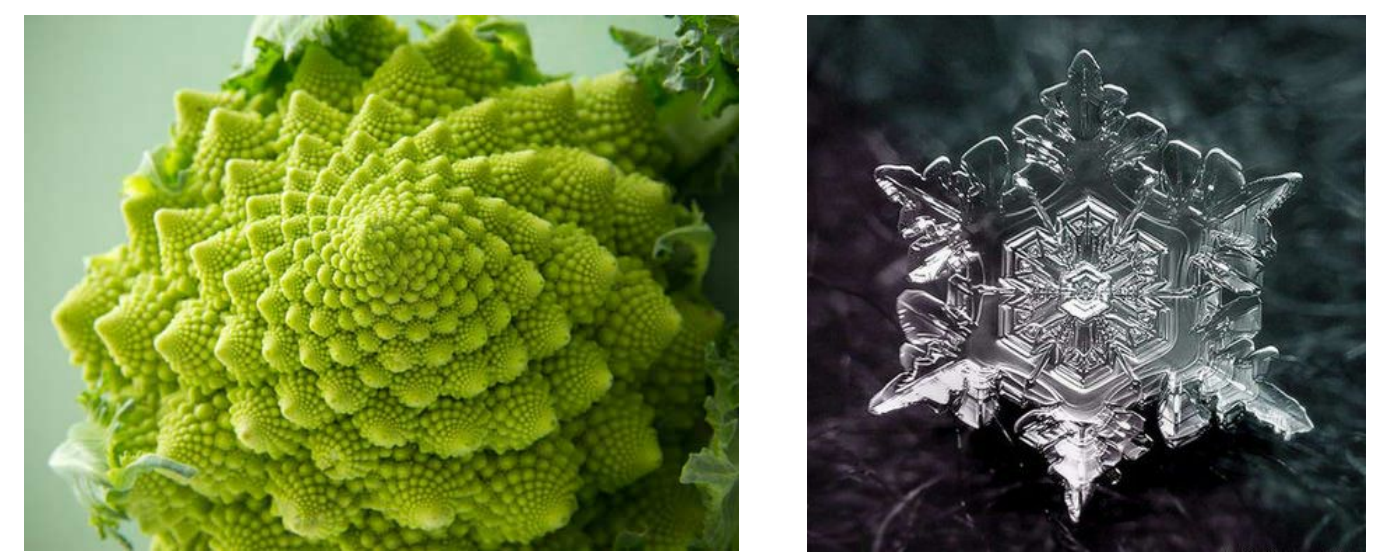

Слики 10 и 11 - Фракталната природа на романеско брокула и снегулката

Еволуцијата со природна селекција секојдневно доаѓа до дизајни со кои го извлекува најдоброто од дадените ресурси. Фракталната геометрија ни дава поширок речник со кој може да прочитаме повеќе од книгата на природата. Но, таа не запира кај живите организми. Планините, реките и облаците се исто така вклучени.

Оттука, можеме да кажеме дека фракталите се врската меѓу природата, математиката и дизајнот.

\subsection{2 Биолуминисценција}

Биолуминисценција е појава на светење предизвикана од хемиска реакција во внатрешноста на жив организам. Таа уште се нарекува и „ладна“ светлина, бидејќи помалку од $20 \%$ од неа се претвора во топлина при самиот процес на светење. Повеќето биолуминисцентни организми можат да се најдат во океанот, како што се некои риби, бактерии и медузи, но има и такви кои се на копно или во воздухот, како одредени видови печурки и светулките. 


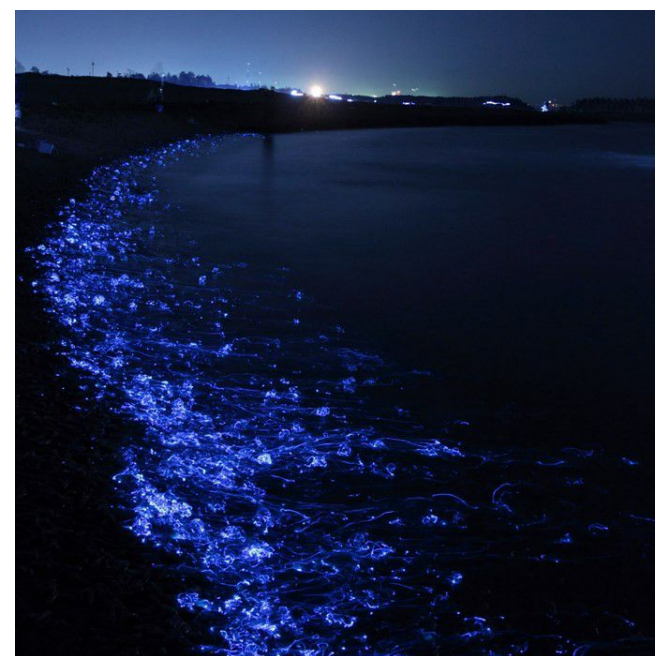

Слика 12 - Планктони во светлечкиот залив во Пуерто Рико, откриени во 2010 година

Хемиската реакција која резултира во биолуминисценција се состои од две материи: луциферин и луцифераза, или фротопротеин. Бојата на светлината која е резултатот на оваа појава, зависи од распоредот на молекулите на луциферинот. Некои биолуминисцентни организми ја синтетизираат оваа материја самите во своите тела како планктоните Ноктилука, а некои не, како Зоопланктоните.

Мојата особена фрасцинираност од овие организми потекнува од Ноктилука, кои се видови планктони кои живеат на Карибите и навечер светат со неонска тиркизна боја. Овде тие се наоѓаат во такво изобилство, што водата свети неонско сино кога би ставиле рака во неа, или би прошол чамец низ неа.

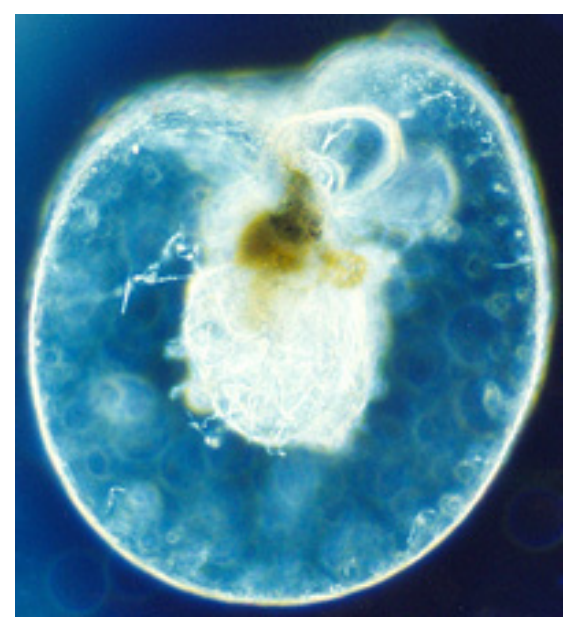

Слика 13 - Noctilluca под микроскоп 
Научниците мислат дека Ноктилука свети за да ги исплаши предаторите. Нивната биолуминисценција исто така служи за да привлече внимание на поголемите риби кои би ги изеле предаторите на планктоните.

Како најблиска варијанта на биолуминисценцијата која може да се примени во мојот дизајн, со цел седиштето да биде лесно видливо во темнина е појавата на фосфоресценцијата. Тоа е појавата на реемитување на апсорбираната светлина за подолго време (околу 8 часа), и тоа без присутво на изворот на светлина кој го наполнил телото кое свети.

Фосфоресценцијата е веќе применета од човекот во најразлични сфери на секојдневниот живот, како вештачка боја која се полни на соларна светлина или електрична светилка, и навечер емитува светлина. Со неа се премачкуваат излезите и стрелките во случај на пожар на аеродромите и во институциите, стрелките на часовниците, а се прават и различни детски играчки и првоаприлски маски.
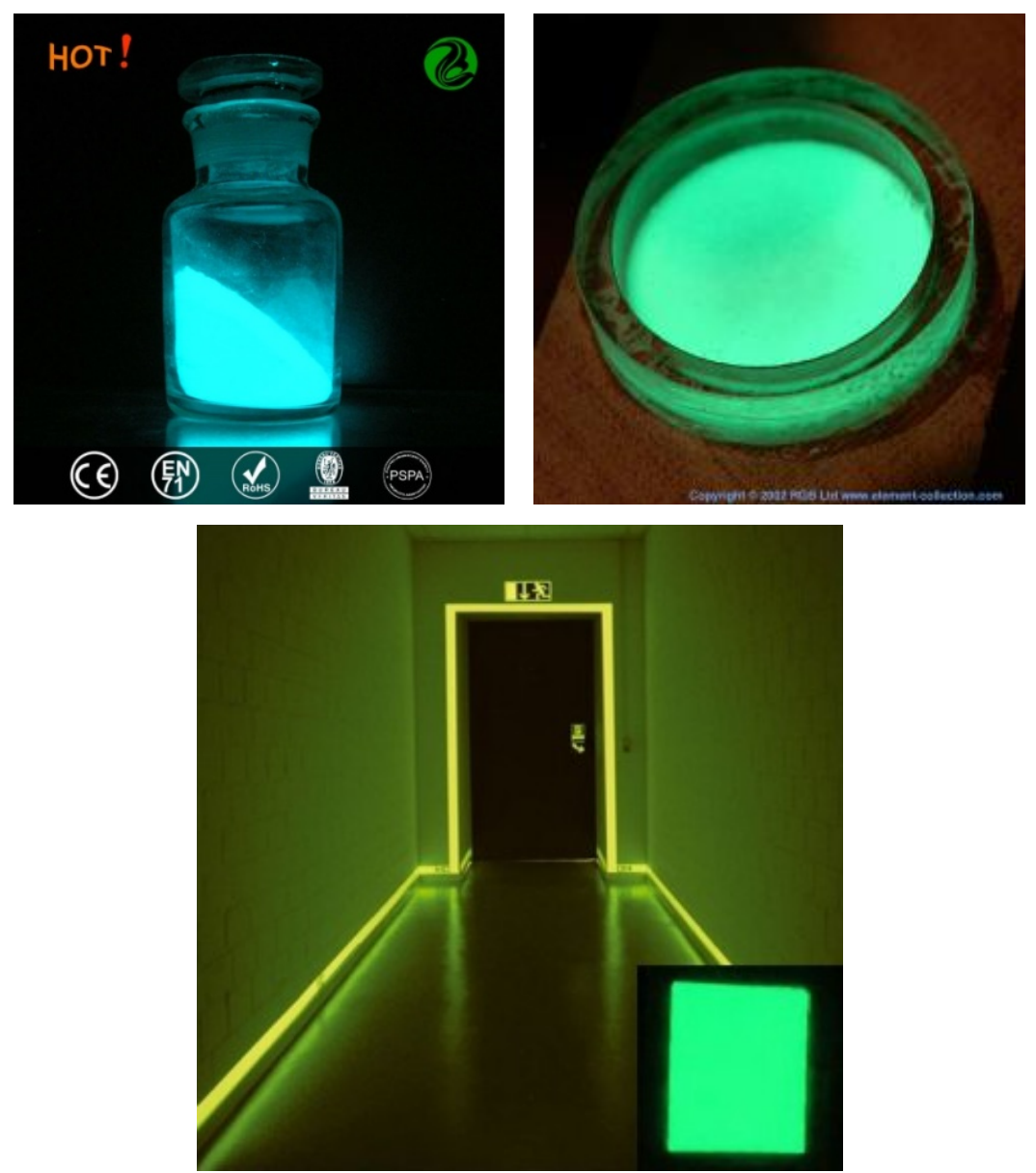

Слика 14-16 - Примена на фосфроресцентна боја кај тастери и излези 


\section{9 Генерирање концепти}

Следната фраза во развојот на производот е генерирање на концептни решенија кои имаат за цел да да ја задоволат истата потреба на различни начини.

\section{1 Концепт бр. 1}

Концепт бр. 1, кој е прикажан на сл. 1-12 се состои од едноставна форма изработена од полипропилен со дебелина од $2 \mathrm{~mm}$. Изработив неколку различни варијации на истата тема, во вид на површински обработки. Првата е олеснета конструкција со отвори со органска, целуларна фрорма, втората го применува трендот на half- tone pattern, додека третата е со детски додаток во форма на ранче за складирање на потребните работи кои ќе ги носи детето.
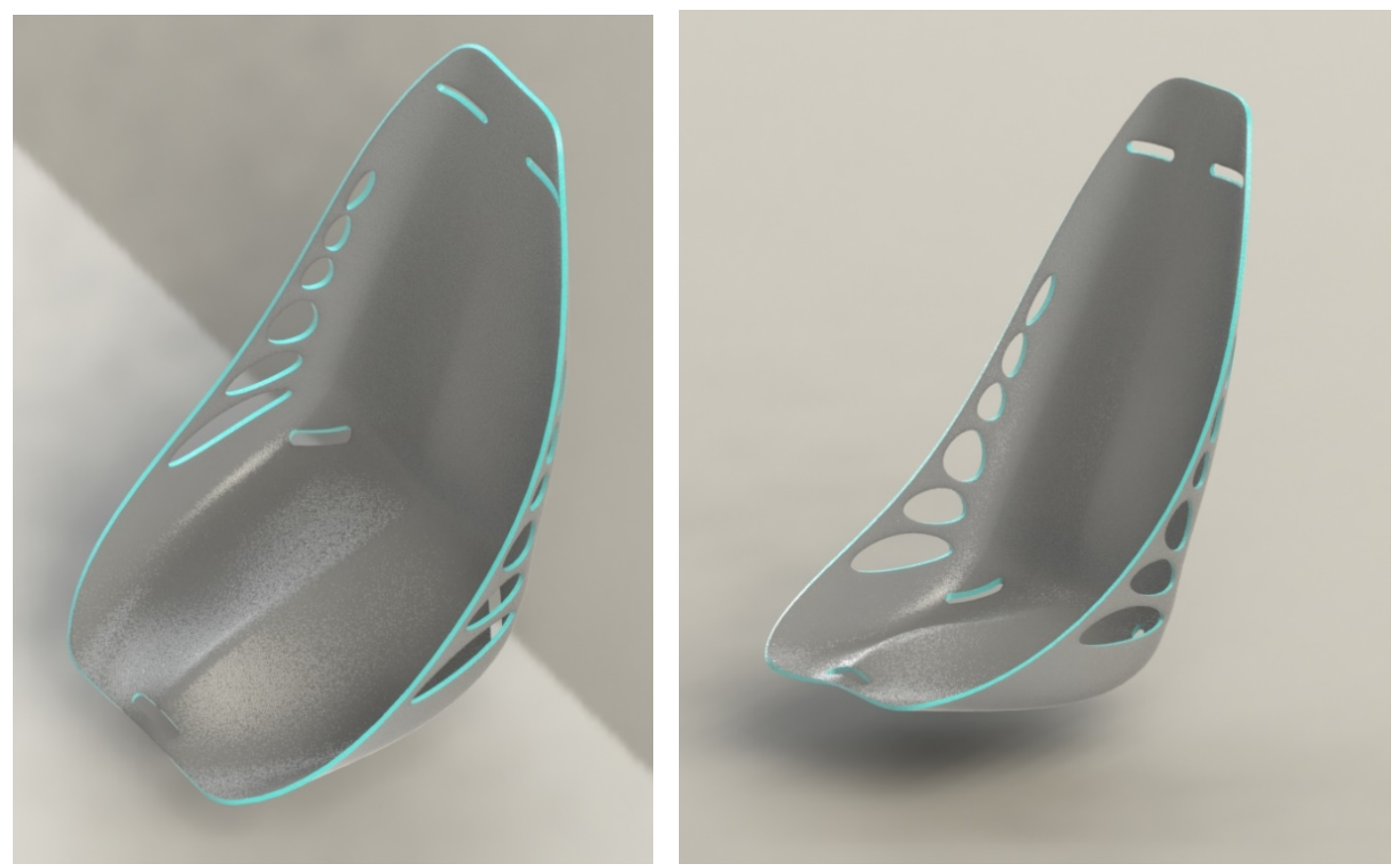

Слика 1 и 2 - Варијанта 1 на првиот концепт 

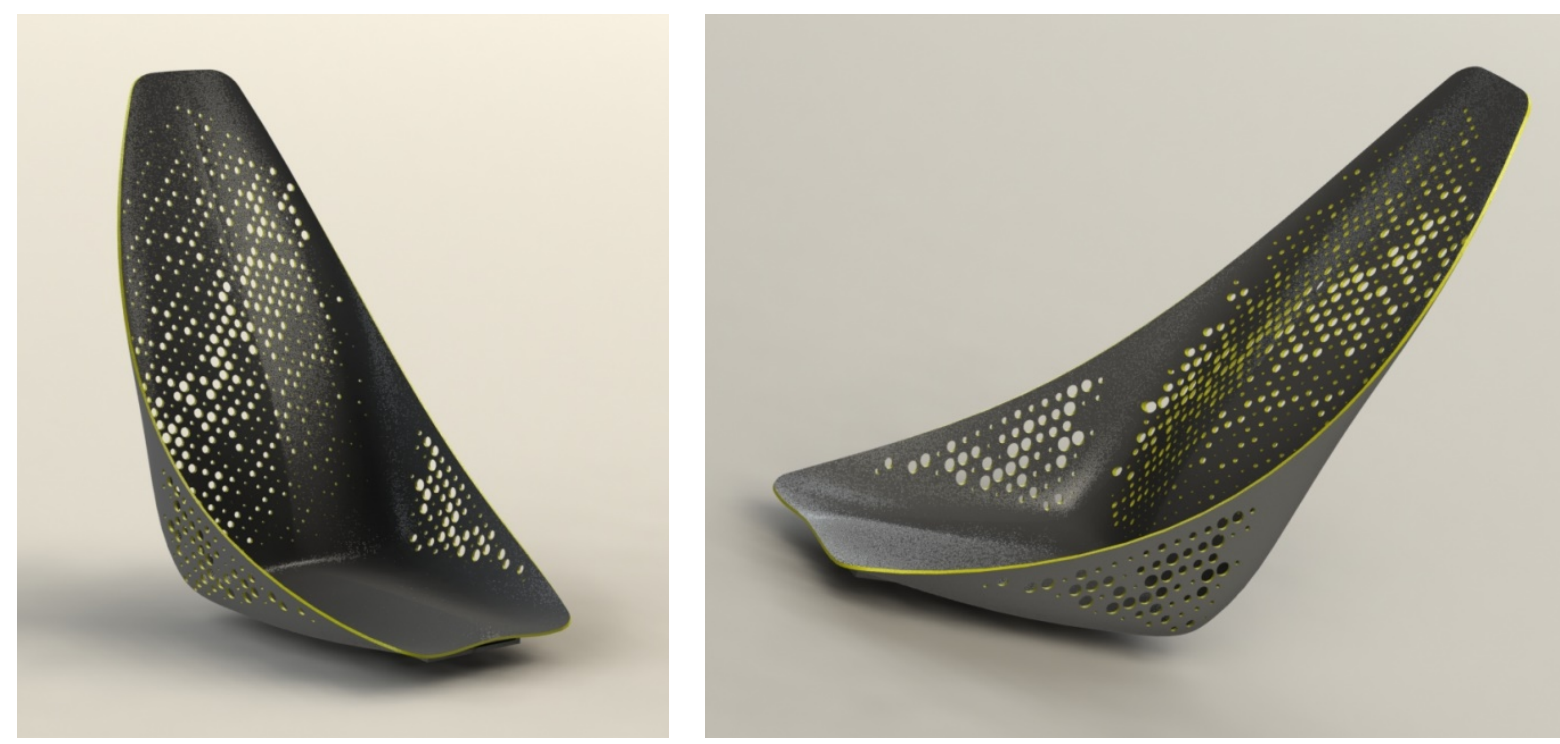

Слика 3 и 4 - Варијанта 2 на првиот концепт, применет Half-tone pattern
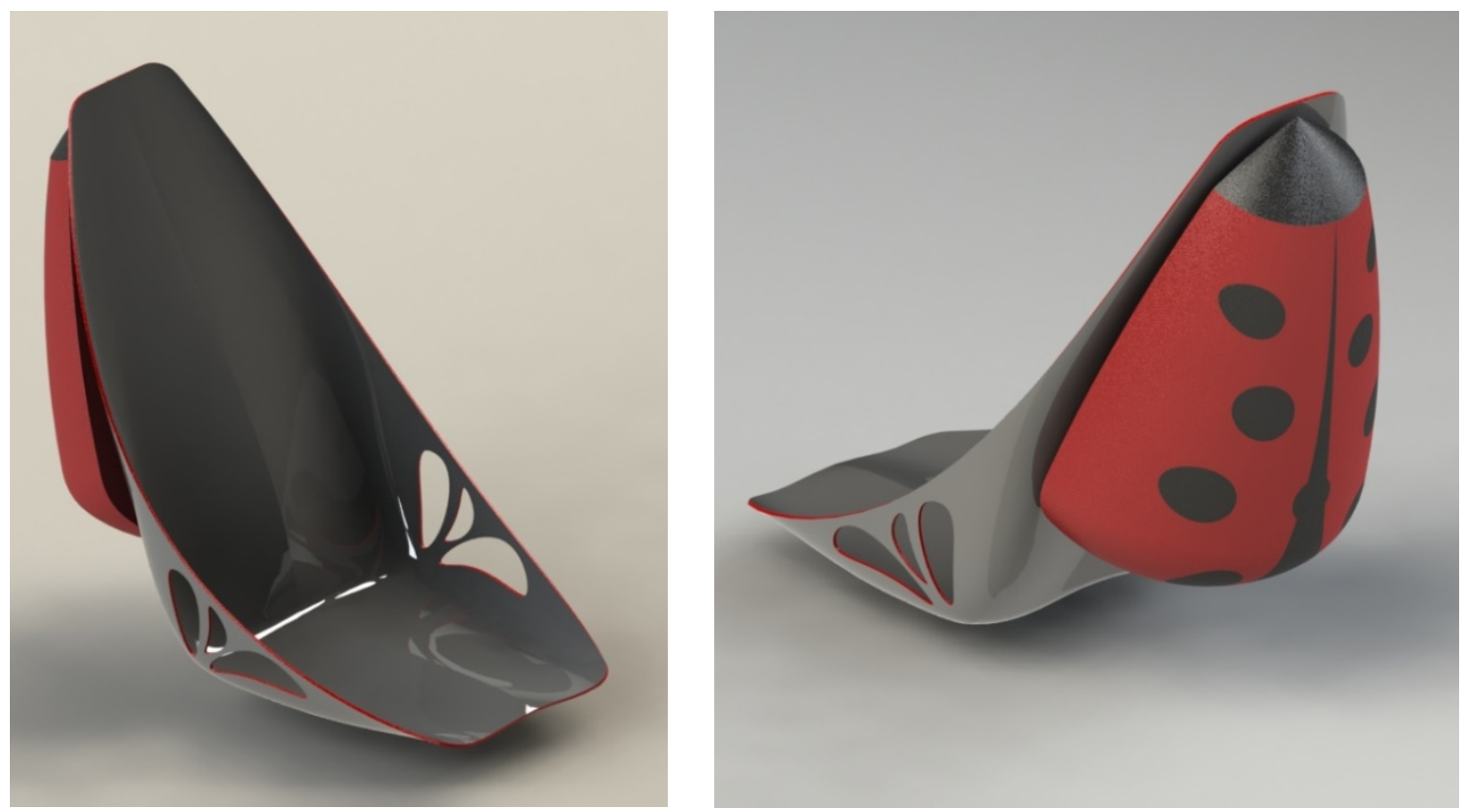

Слика 5 и 6 - Варијанта 3 на првиот концепт, багажник за складирање 


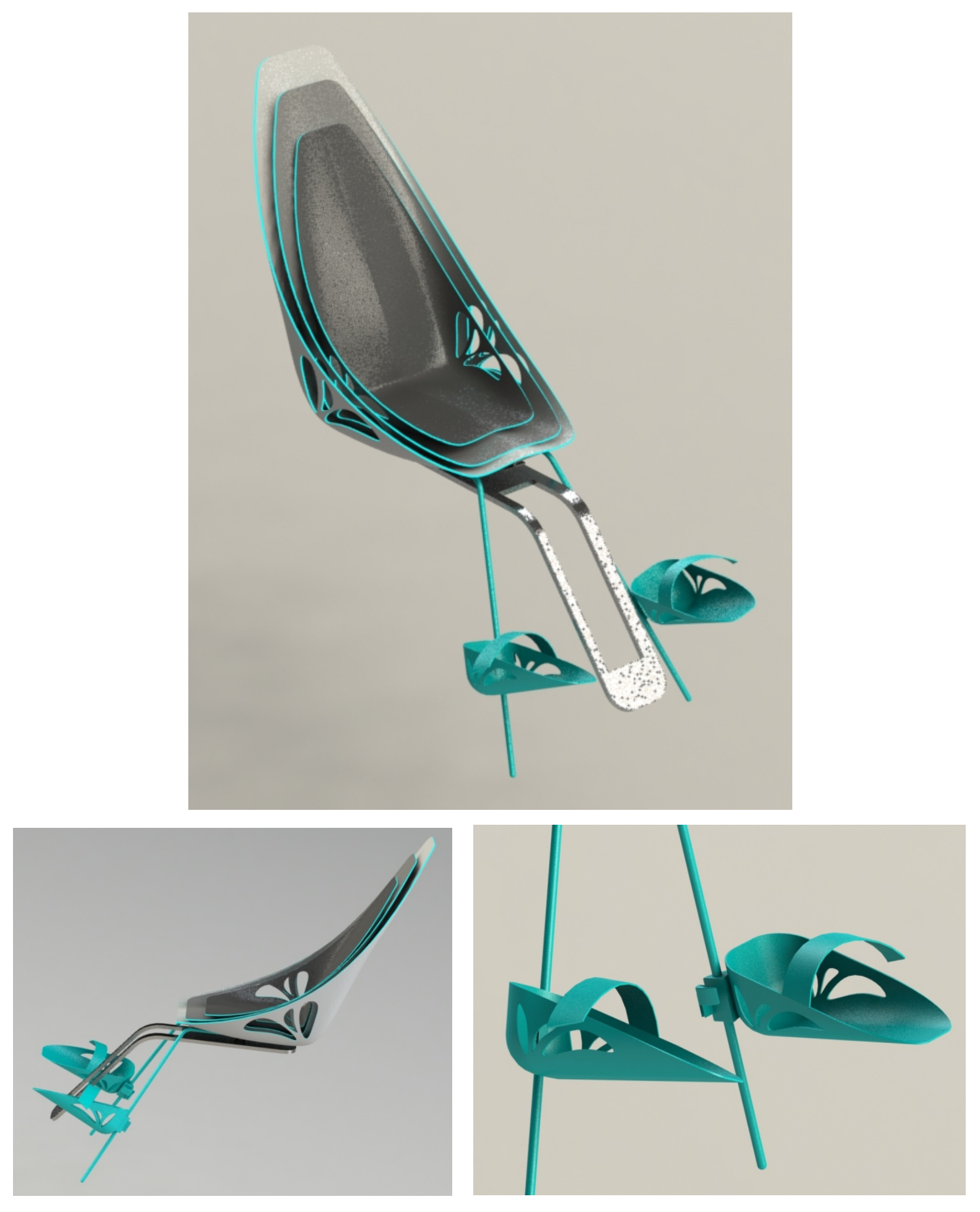

Слики 7-9 - Склопени трите делови на првиот концепт 

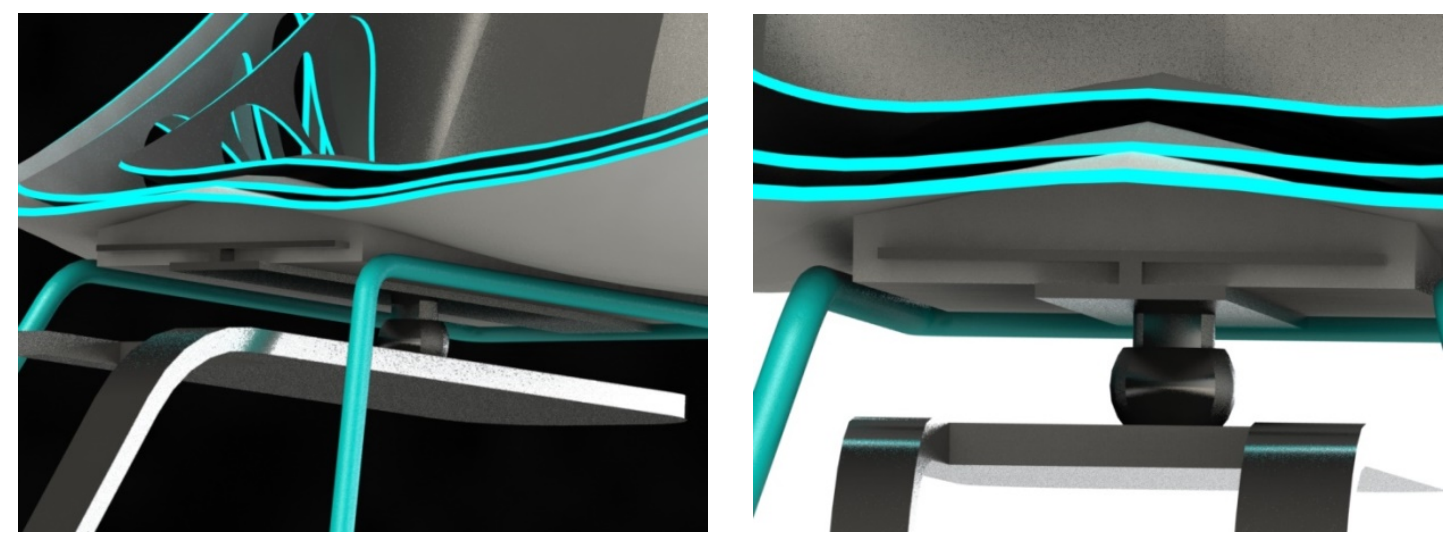

Слики 10 и 11- Детален дизајн на првиот концепт

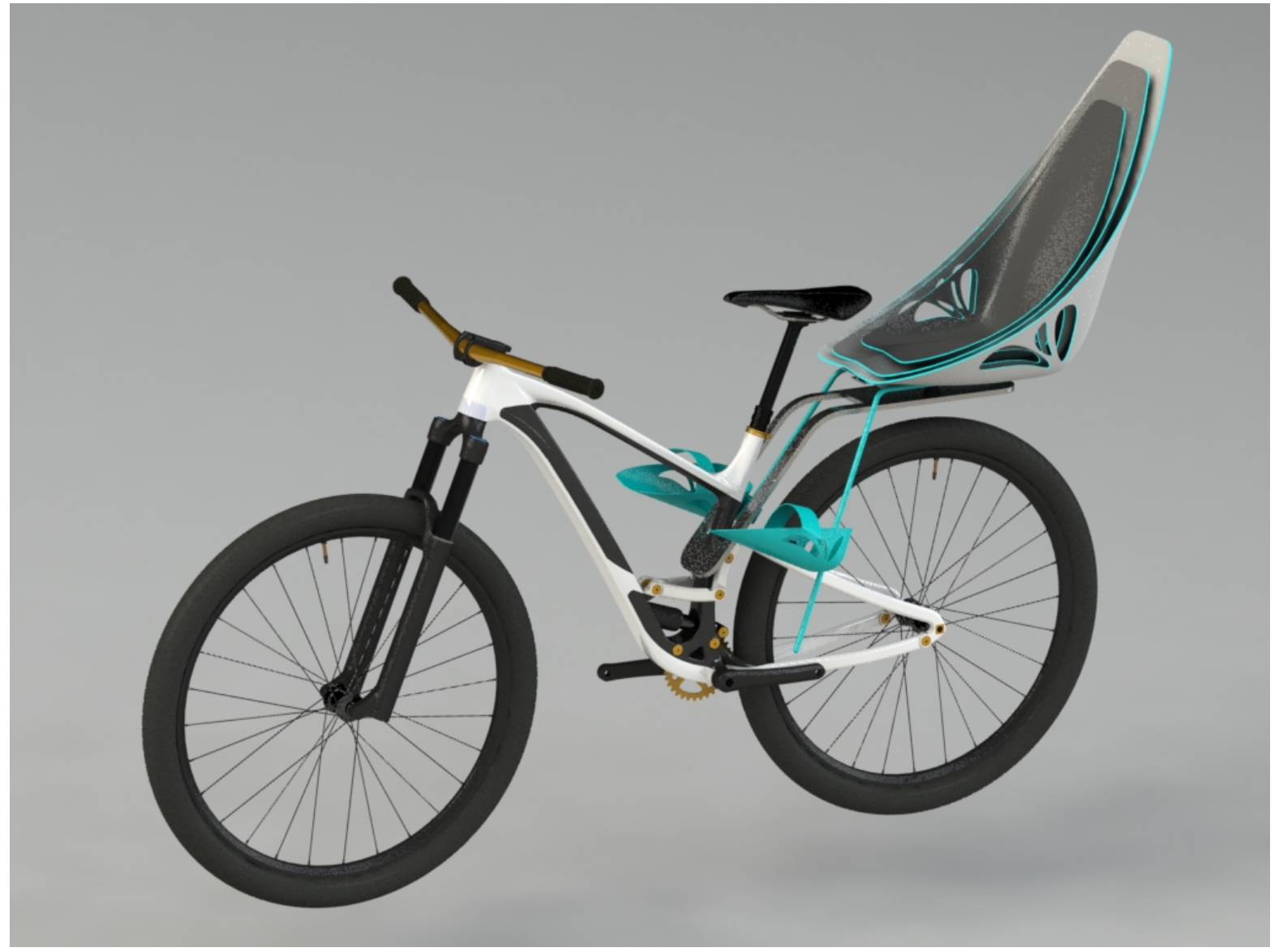

Слика 12 - Првото концептно седиште монтирано на велосипед 


\section{2 Концепт бр. 2}

Вториот концепт претставува идејно решение со поголеми габаритни димензии, но помала маса и подобрен дизајн. Трите фрактали се предвидени да бидат изработени од EVA полимер, кој е поудобен и помек. Бидејќи се работи за дизајн за деца, важно е да нема остри рабови. За разлика од претходниот концепт, овде е предвиден и дел за нозете кој е интегриран со делот за седење. Тоа е со цел да се елиминира можноста нозете на детето да допрат до задното тркало. Негативна страна е што колената се многу блиску, и се во неприродна положба.
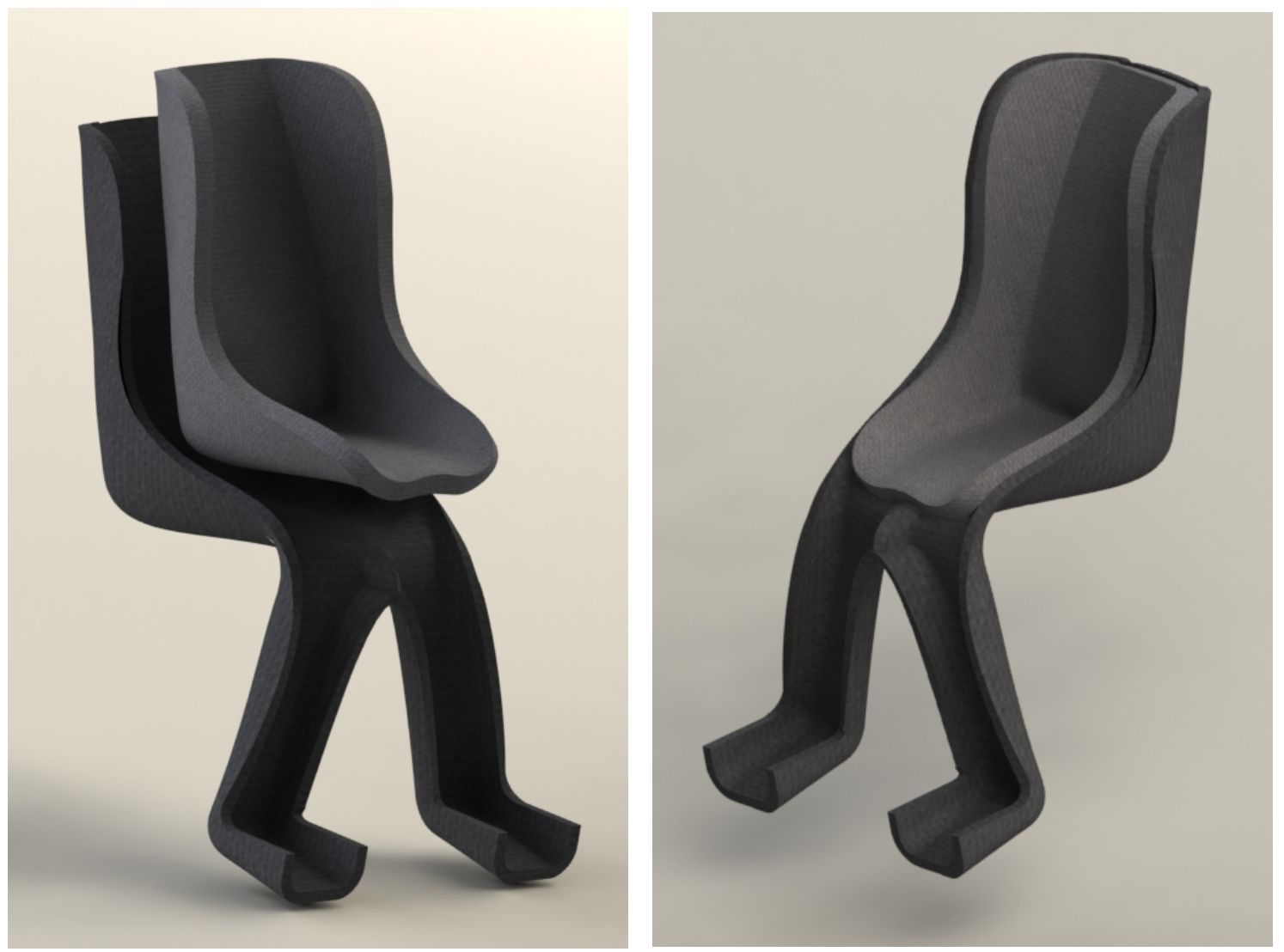

Слика 13- Концепт бр. 2

\section{3 Концепт бр. 3}

Третиот концепт е комбинација на добрите карактеристики од претходните два, полипропиленска основа на која се поставени трите фрактали изработени од EVA полимер, кои се меѓусебно залепени со велкро материјал. Со тоа е овозможено лесно монтирање и демонтирање во зависност од возраста на 
детето. Делот за нозете е целосно независен, но визуелно продолжува и го надополнува обликот на горниот дел. Двата дела се спојуваат со жлебови. Пред детето да наполни една година, делот за нозе се вади и со тоа дополнително се смалува габаритот и масата на дизајнот. Седиштето е малку пошироко од претходните концепти, покомотно, а детето се осигурува со појас со 5 точки на прицврстување, кој според повеќе истражувања ${ }^{15}$ на интернет, се покажал како побезбеден од појасите со 3 неподвижни точки.
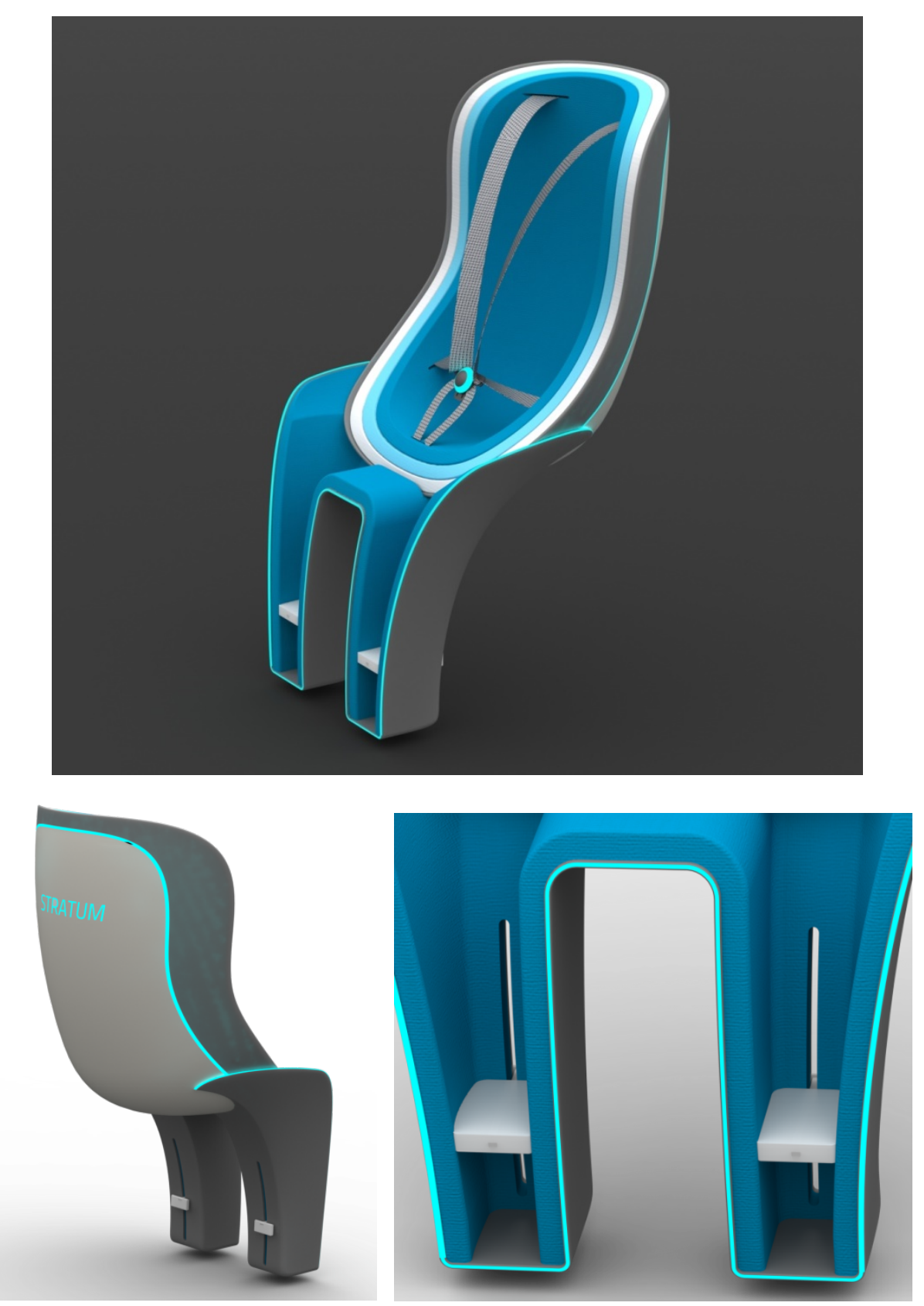

Слика 14-16 - Концепт бр. 3

${ }^{15}$ https://carseatresearch.com/is-a-5-point-harness-car-seat-better-than-a-3-point-one/ 


\section{4 Оценување на концептите}

Одбирањето на концепт кој најсоодветно ги исполнува барањата на таргет групата и инженерските спецификации беше спроведено со методот на пајакова мрежа, каде секој концепт е оценет на скала од 0 до 3 според 10 различни критериуми. Концептот кој има најголема плоштина на полигонот е најблиску до идеалните карактеристики кон кои е насочен развојот на овој производ.

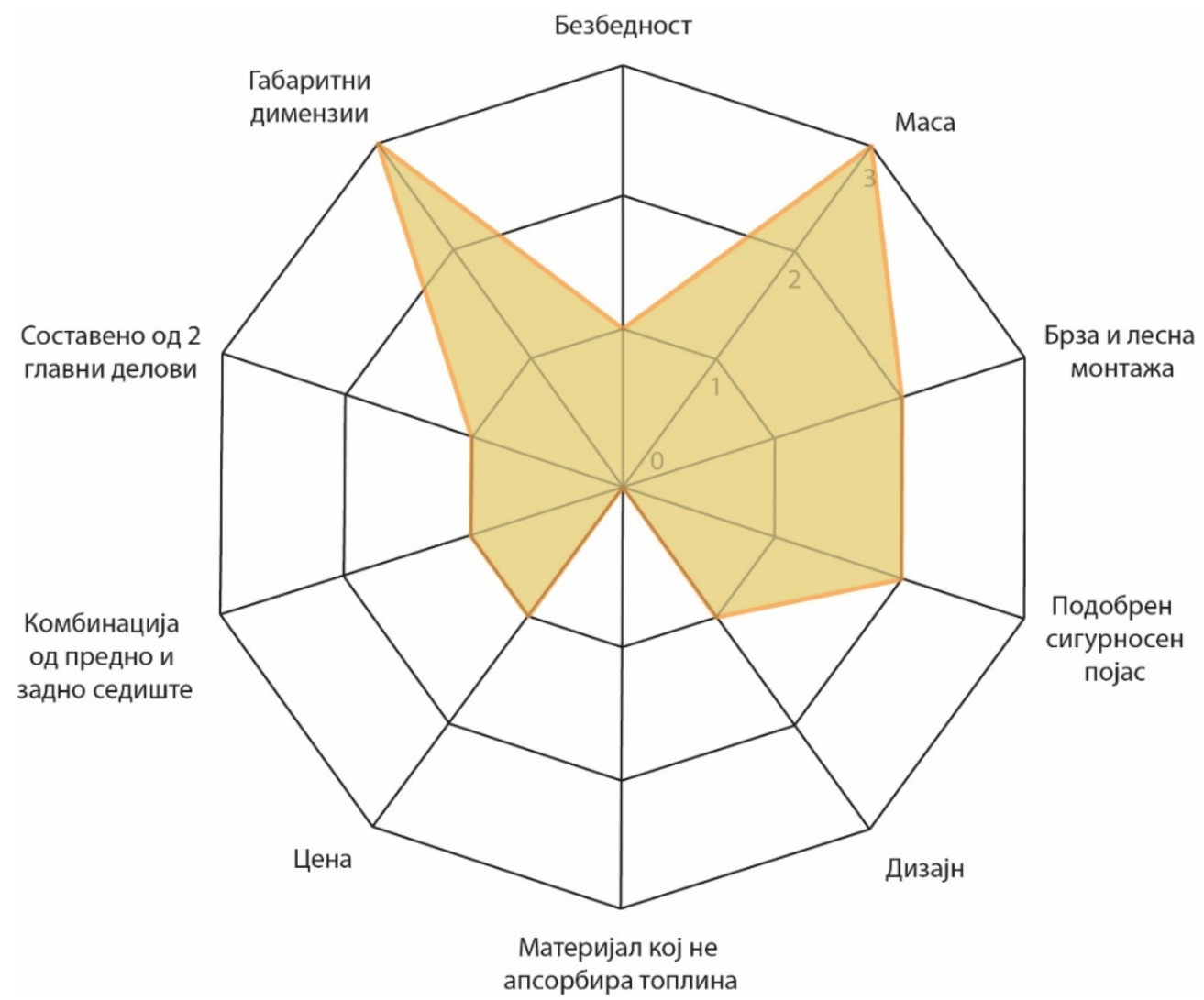

Слика 17 - Дијаграм за концепт бр. 1 


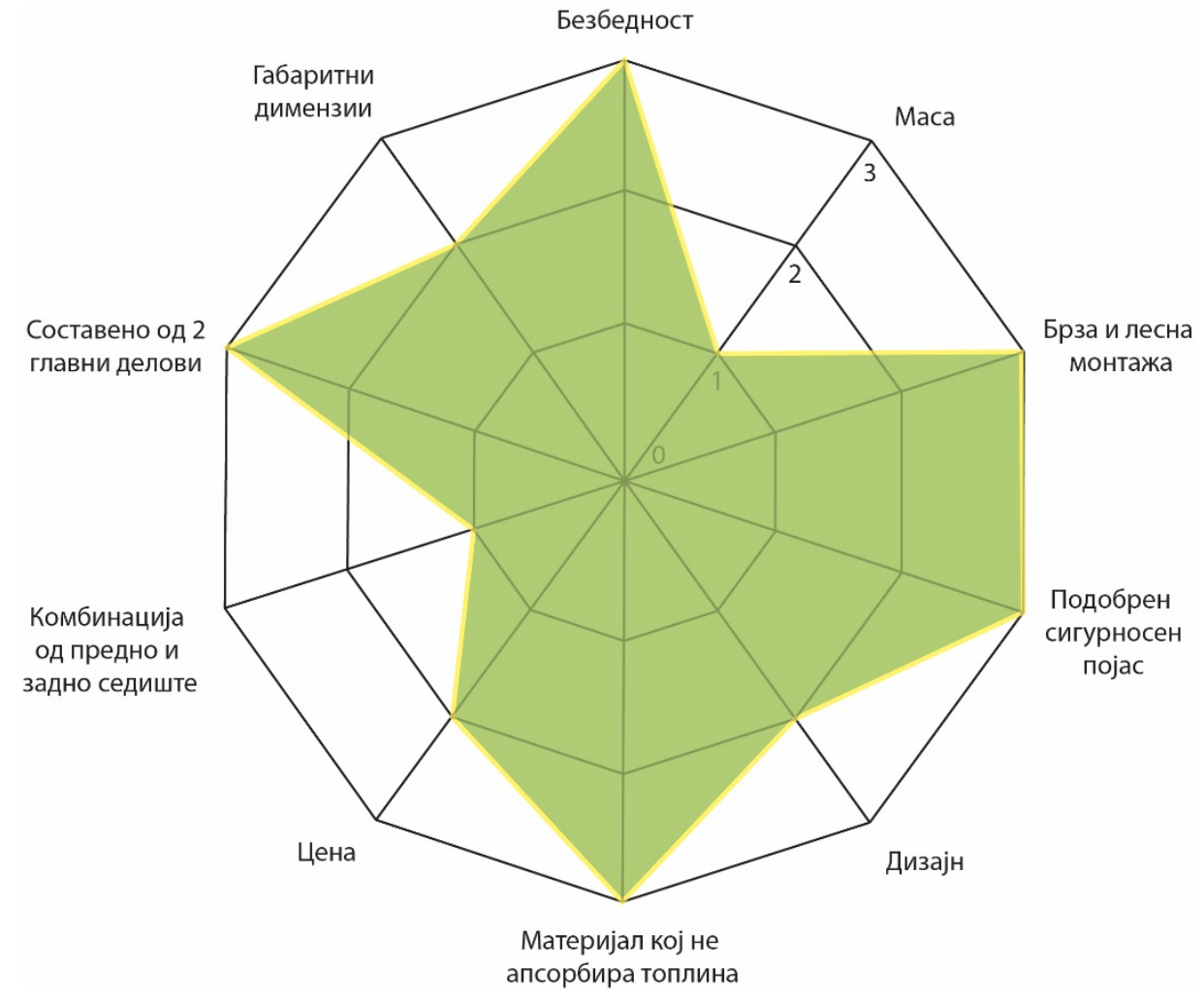

Слика 18 - Дијаграм за концепт бр. 2

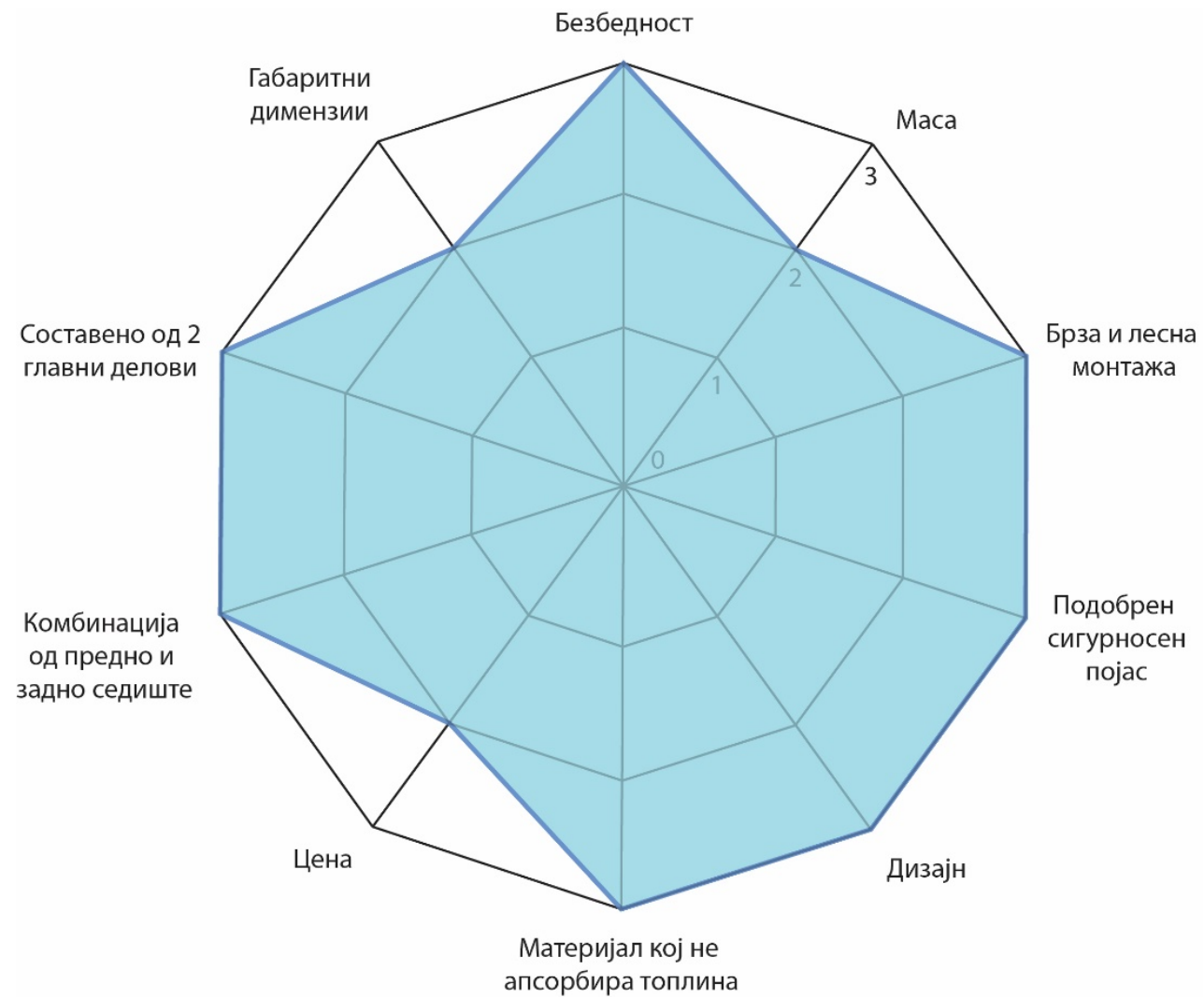

Слика 19 - Дијаграм за концепт бр. 3 
Максималната оценка која може да ја добие еден концепт е 30 , тоа би значело дека добил оценка 3 по сите критериуми. Од самите дијаграми е видливо дека споредбено, вториот концепт ги исполува барањата со поголема плоштина за разлика од првиот концепт, а тоа значи и повисока оценка- 24/30 наспроти 15/30. Третиот концепт, кој е претставен на следната слика, убедливо го зазема првото место со резултат 27/30. Тоа значи дека ова идејно решение ќе биде понатаму подетално развиено, и ќе бидат предложени дополнителни идеи за негови додатоци, како и техничка документација. 


\section{0 Детали и завршна обработка}

\subsection{CAD модел, основни составни елементи и склопен цртеж}

Избраниот концепт на велосипедско седиште за превоз на деца е дизајниран како склоп кој се состои од два главни делови: дел за седење и дел за сместување на нозе (сл. 10.1). Делот за седење има четири елементи:

1. Слој 1 - седиште за возраст од 0 до 1 година;

2. Слој 2 - седиште за возраст од 1 до 3 години;

3. Слој 3 - седиште за возраст од 3 до 5 години и

4. Подлога на седиштето.

Делот за сместување на нозете се користи за возраст над 1 година на детето, и се состои од:

5. Подлога за нозе;

6. Држачи за стапала;

7. Перниче за нозе;

8. Механизам за закопчување на појасот.

На сликата 10.1 не се поставени ремените од појасот, бидејќи се усвоени стандардни, како кај детските седишта за во автомобил.

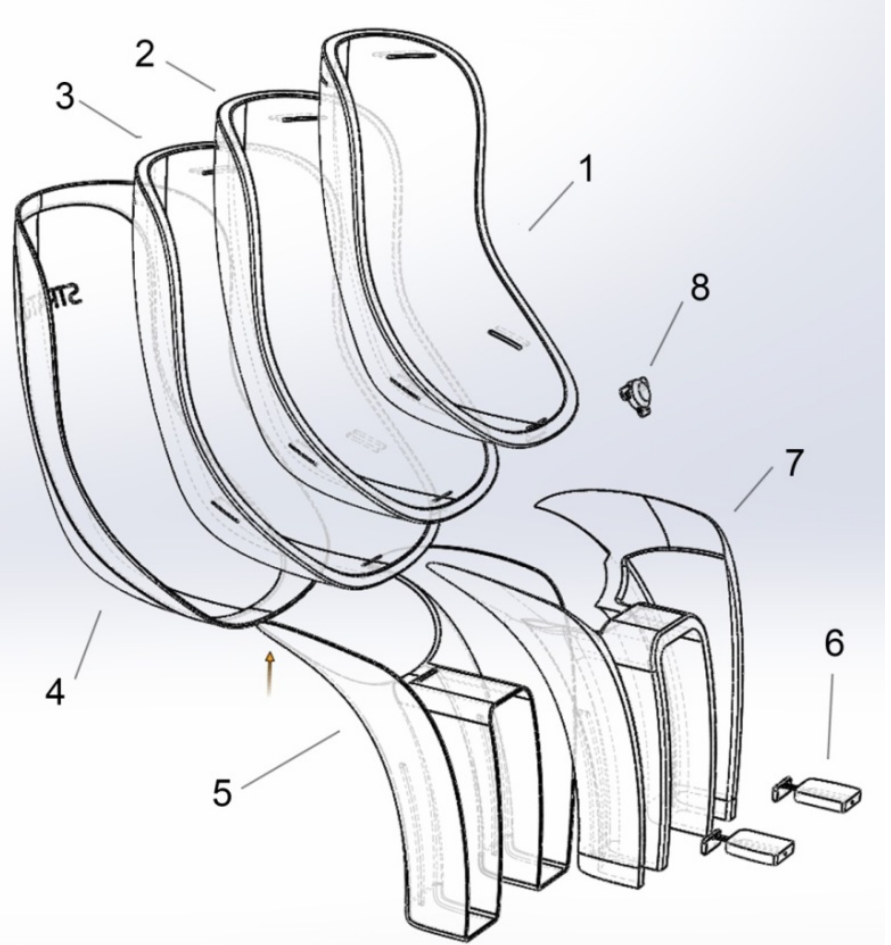

Слика 10.1 - Составни елементи на седиштето 
Редоследот на склопување е интуитивен, формите влегуваат една во друга и имаат логичен распоред (слика 10.3). Слоевите меѓу себе се лепат со велкро лента поставена на 4 места на задната страна од секој слој. Држачите за стапала се подвижни и во зависност од возраста се поместуваат горе - долу. Во крајната положба се фиксираат со помош на стега, како на слика 10.2.

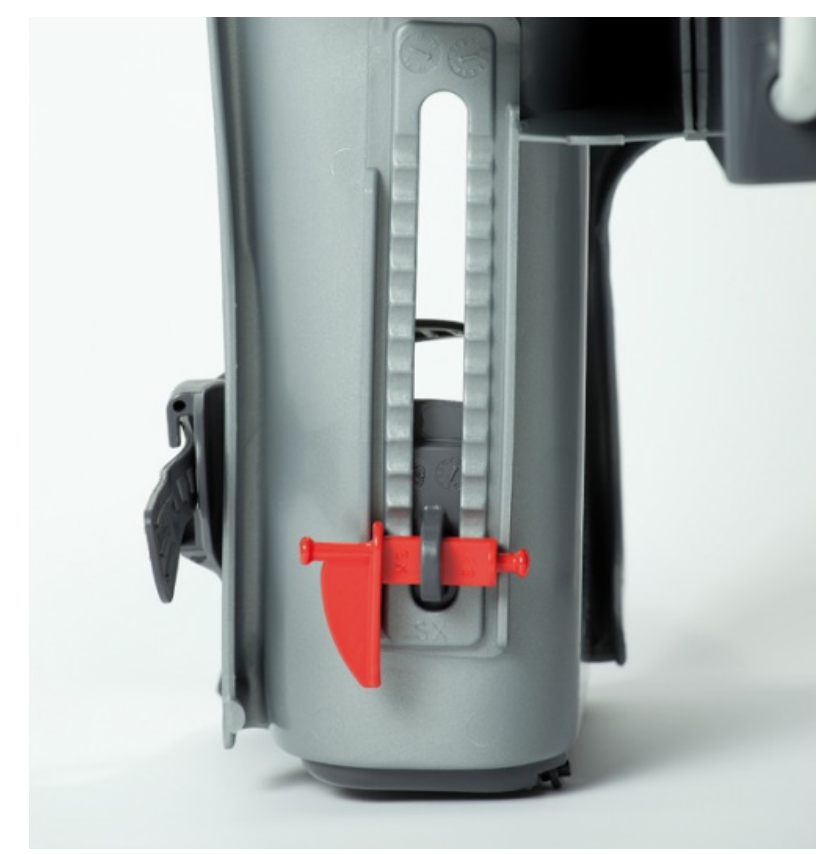

Слика 10.2 - Механизам за поместување на држачите за стапала 


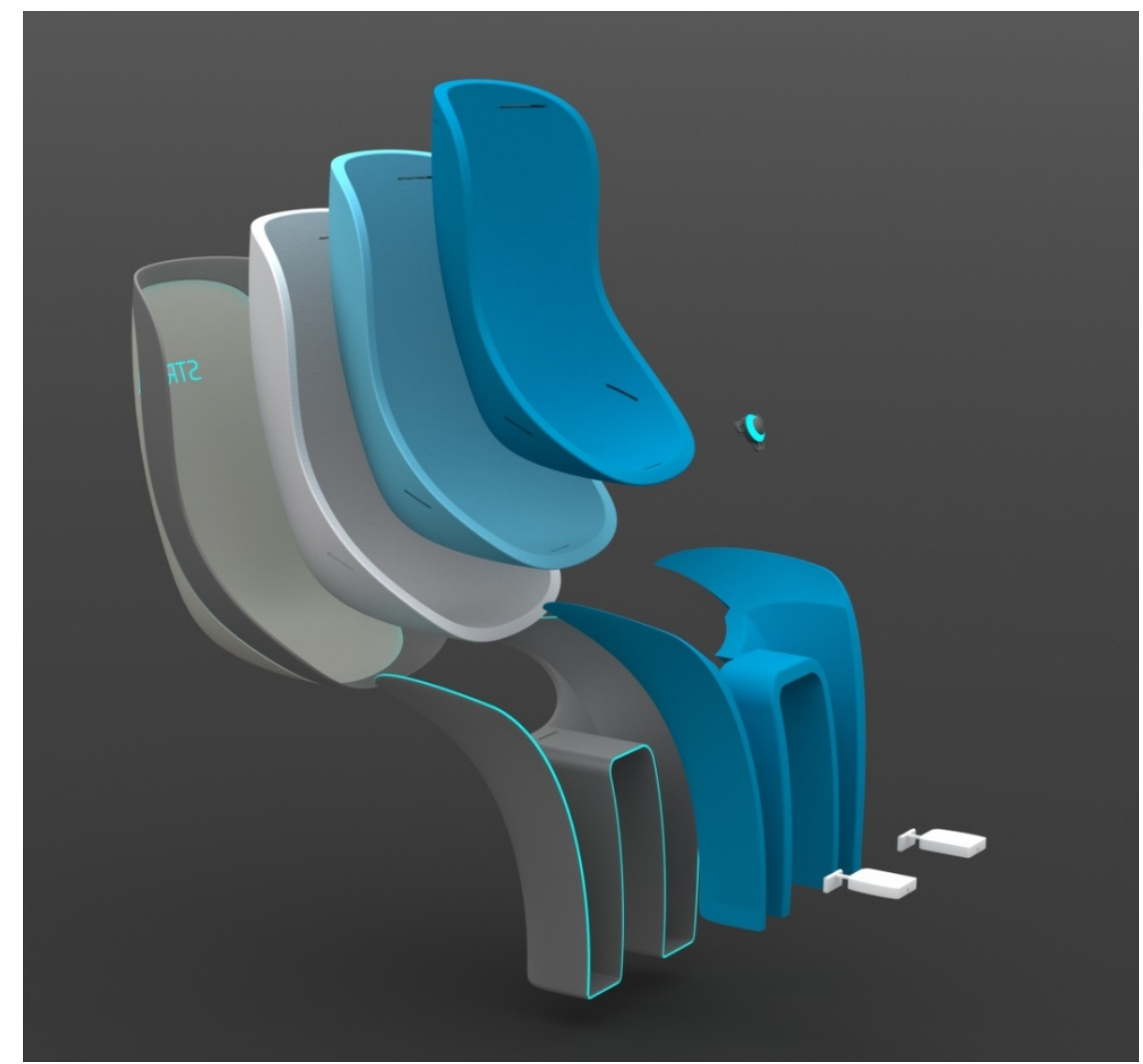

Слика 10.3 - Склопен цртеж

\section{2 Сигурносен појас со 5 точки}

Сигурносниот појас кај ова седиште е предвиден да има 5 неподвижни точки, од кои две се наоѓаат кај рамената, две кај колковите и една меѓу нозете на детето (слика 10.4). Составен е од ремен, шноли и механизам за закопчување.

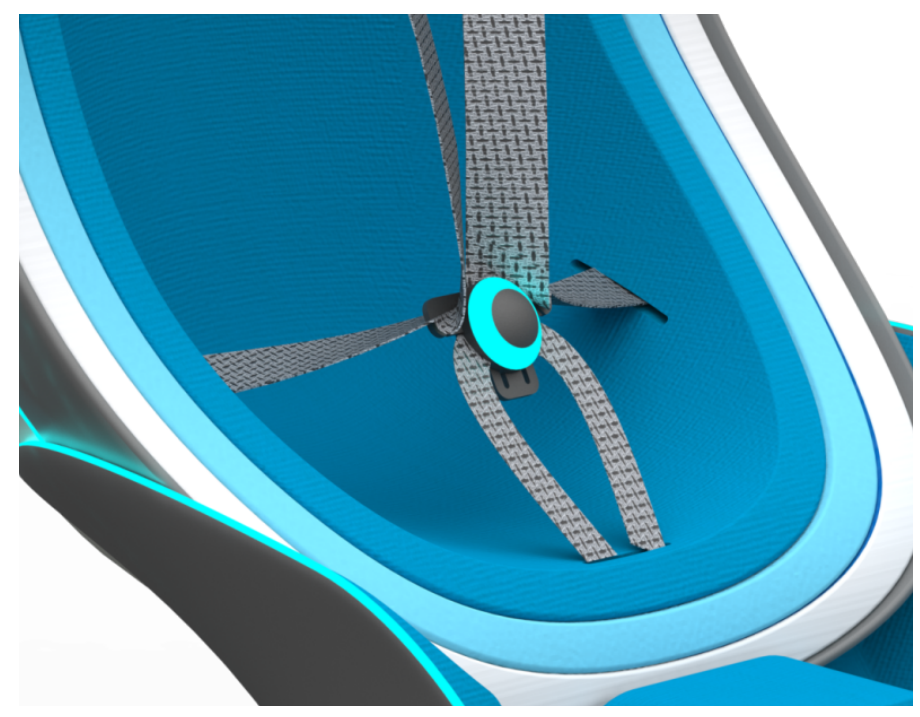

Слика 10.4 - Сигурносен појас со 5 точки 
Сивиот дел во средината претставува копче за ослободување на појасот, чија сила на притисок треба да е малку поголема, како безбедносна мерка, за детето да не може само да го откопча појасот додека велосипедот се движи. Тоа се постигнува со пружина во механизмот со поголема крутост. Во следната табела $10.1^{16}$ се дадени вредностите на силата на притисок на детскиот палец за различни возрасти, кога притиска напред и надолу.

\begin{tabular}{l|c|c|c|c|c|c|c|c|}
\hline & & & \multicolumn{3}{|c|}{ Pushing forwards, (N) } & \multicolumn{3}{c|}{ Pushing downwards (N) } \\
Age (years) & Sex & No. & Mean & SD & Range & Mean & SD & Range \\
\hline $2-5$ & $\mathrm{~m}$ & 9 & 28.07 & 9.99 & $17.30-41.60$ & 26.920 & 18.85 & $23.50-53.80$ \\
& $\mathrm{f}$ & 8 & 30.92 & 8.66 & $16.80-42.80$ & 34.40 & 14.59 & $13.60-53.90$ \\
\hline $6-10$ & $\mathrm{~m}$ & 5 & 88.80 & 28.55 & $53.40-126.60$ & 85.08 & 34.18 & $51.40-132.10$ \\
& $\mathrm{f}$ & 10 & 70.22 & 24.61 & $36.70-107.70$ & 71.14 & 33.56 & $27.80-119.50$ \\
\hline
\end{tabular}

Табела 10.1 - Ранг на силата на притисок на палецот кај деца

\section{3 Кацига со орактален обод}

Секако дека еден од одлучувачките фрактори за безбедноста при возењето на велосипед не е само детското седиште, туку и кацигата која тоа ја носи. На пазарот веќе постојат најразлични варијанти на детски кациги. Обликот, димензиите и основните елементи ги преземав од постоечки модел, бидејќи безбедноста и удобноста се проверени, и мислам дека во овој дел не треба да експериментирам со дизајнот (табела 10.2).

Најновите кациги за велосипед се прават од покрт полимер, за да се скршат при пад и со тоа да го амортизираат ударот, кој инаку би допрел до главата. За таа цел, од внатрешната страна има обод кој лежи на главата, а е одвоен од полимерниот надворешен дел со воздушен простор.

\footnotetext{
${ }^{16}$ Norris, B. J. and Wilson, J. R., 1995, CHILDATA: The Handbook of Child Measurements and Capabilities Data for Design Safety, Department of Trade and Industry, London, UK.
} 


\begin{tabular}{|c|c|}
\hline Age & $\begin{array}{c}\text { Head } \\
\text { circumference } \\
(\mathbf{c m})\end{array}$ \\
\hline At birth & $34-35$ \\
\hline 2 months & 38 \\
\hline 3 months & 40 \\
\hline 4 months & 41 \\
\hline 6 months & $42-43$ \\
\hline 1 year & $45-46$ \\
\hline 2 years & $47-48$ \\
\hline 5 years & $50-51$ \\
\hline
\end{tabular}

Табела 10.2 - Обем на глава според возраста на детето

Мојот новитет во дизајнот на кацигата е фракталниот (слоевит) обод, се состои од три обрачи: сив, син и бел, со различни дијаметри кои одговараат на различниот обем на главата на децата од трите рангови на возрасти за кои е предвидено седиштето. Слоевите се, исто како и во претходниот концепт, залепени со тенка велкро лента меѓу себе за лесно отстранување. Последниот слој е фиксен, и одговара на дете од 6 години, кога детето достигнува обем на глава на возрасен, што значи дека ако се отстранат ободите, истата кацига може да ја носат и возрасни.

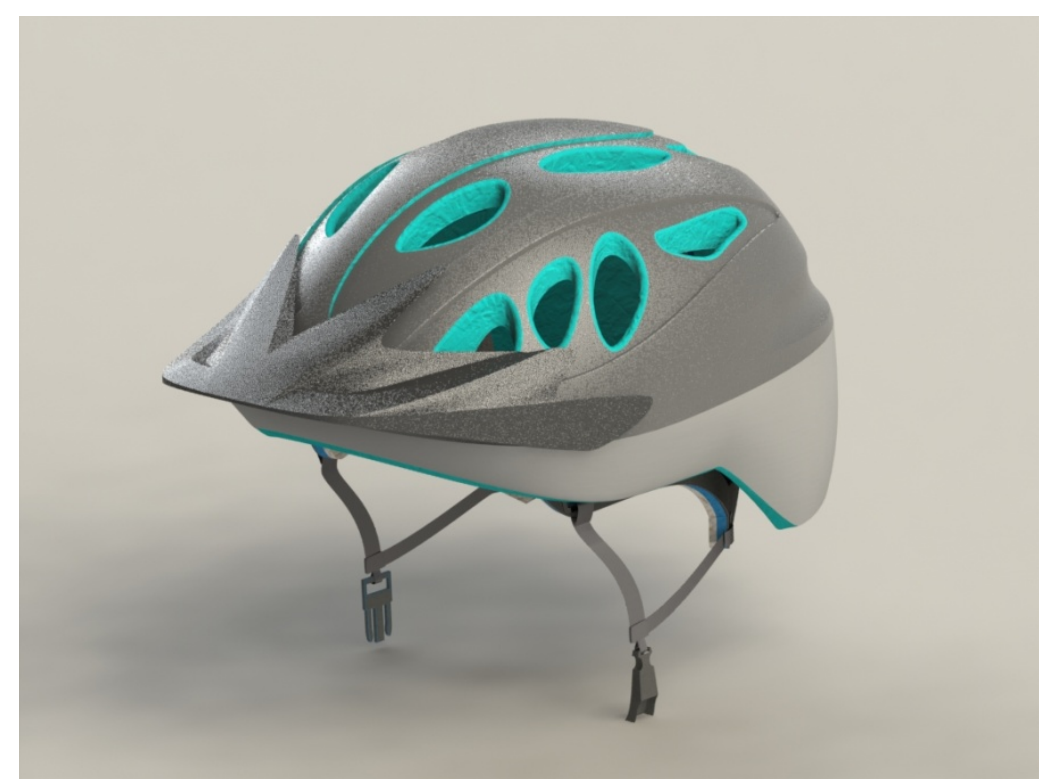



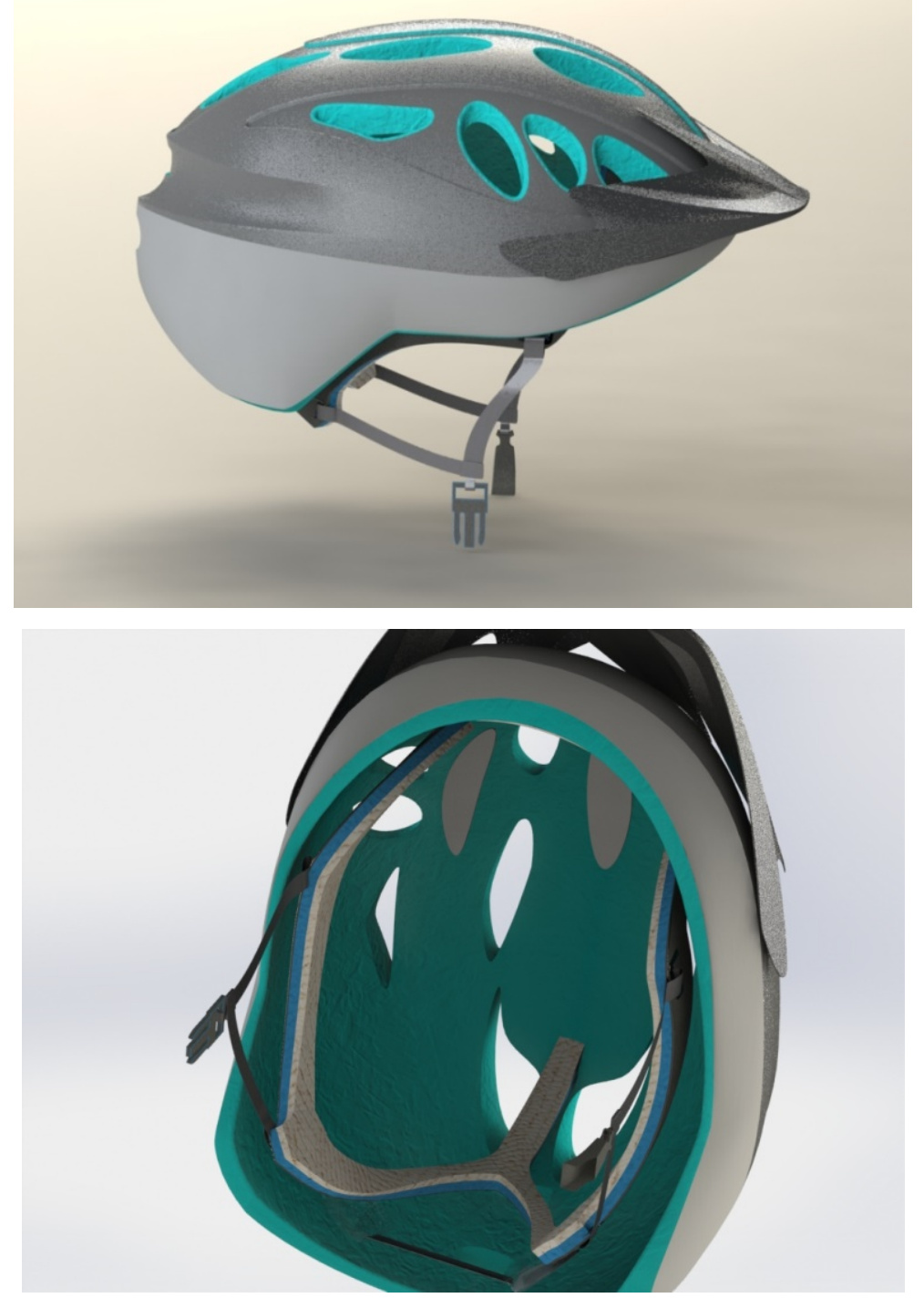

Слики 10.5-7 - CAD модел на кацигата за велосипед
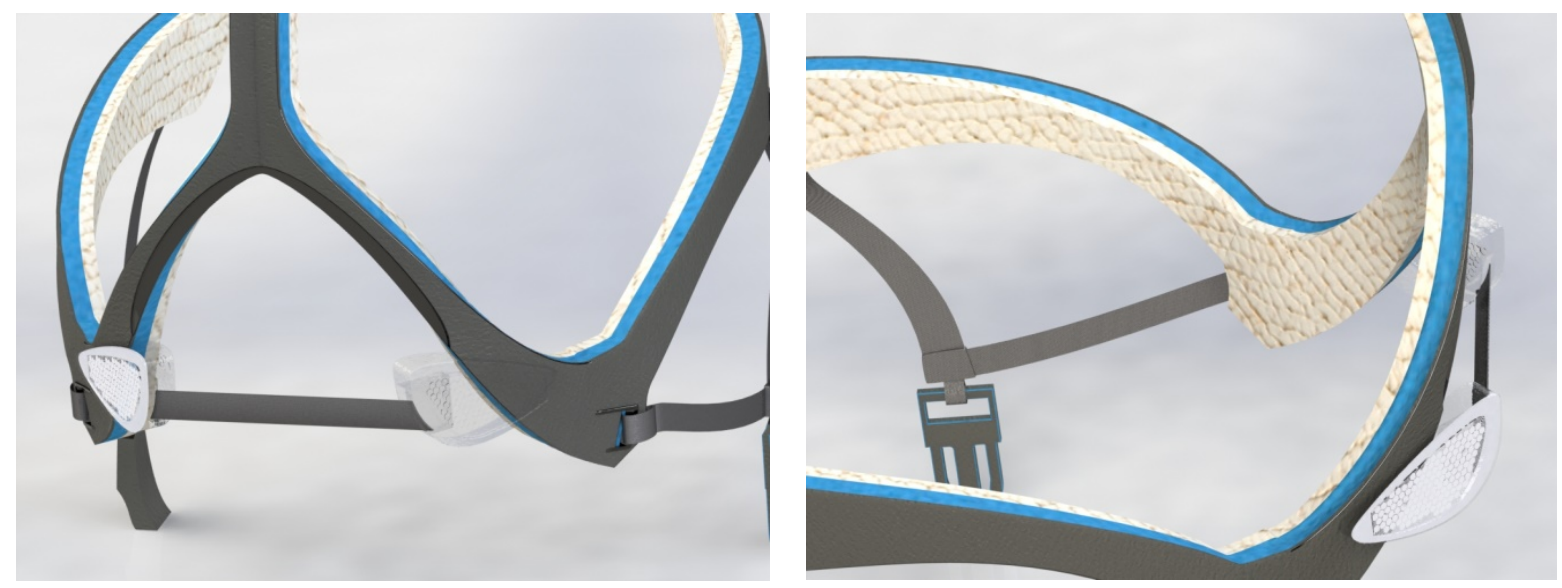

Слика 10.8 и 9 - Модел на фрракталниот слоевит обод 


\section{4 Адаптер за прицврстување на седиштето на велосипедот}

Постојат различни видови адаптери за детски седишта за велосипед. Тие ce делат на предни и задни според местото на поставување, a на road и mountain според типот на велосипедот, во зависност од тоа дали е градски или планински. За првата поделба веќе зборував во претходните поглавја.

Втората поделба е посуптилна, бидеќи разликата меѓу овие два типа на велосипеди се состои во обликот и дебелината на напречниот пресек на цевката од која е изработен рамот. Најчесто планинските велосипеди имаат подебел рам со кружен напречен пресек, додека градските значително потенок, некогаш кружен а некогаш со плоснат (елипсоиден) напречен пресек. Во продавниците кои се специјализирани за велосипеди постојат повеќе варијанти, но јас овде ќе се задржам на двата основни адаптери, кои би требало да одговараат на повеќето велосипеди.

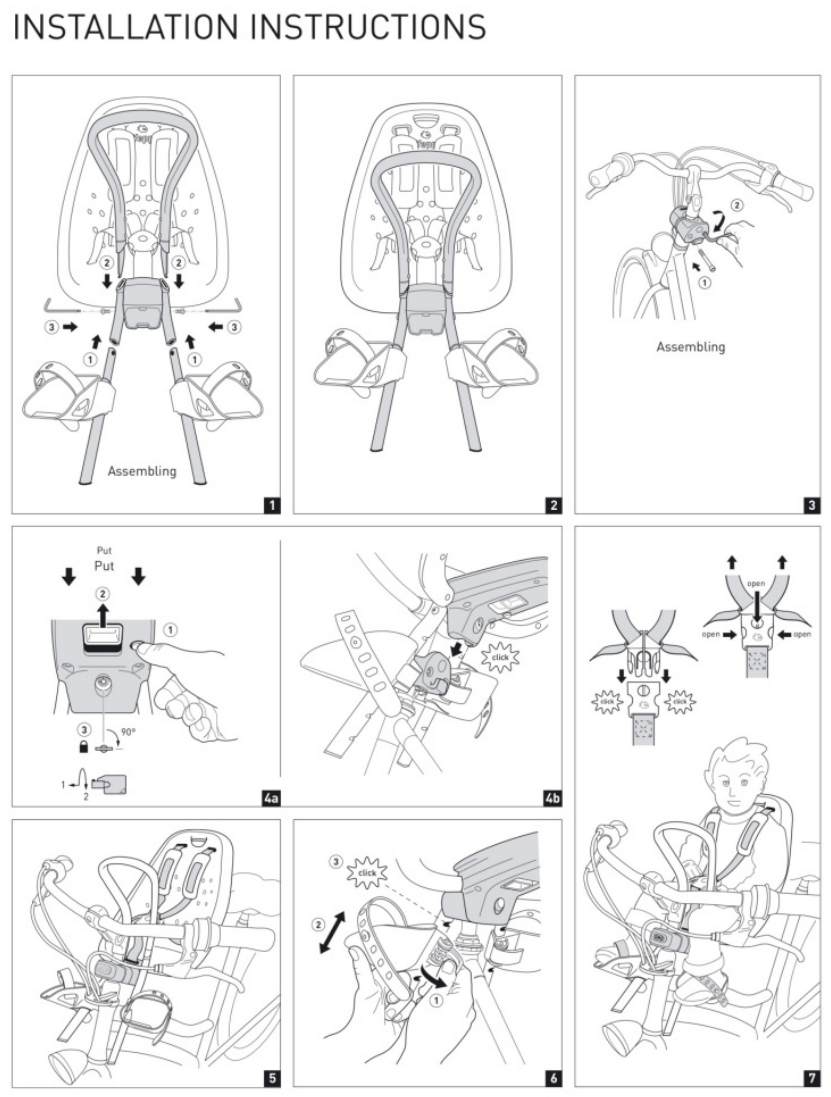

Слика 10.10 - Упатство за монтажа на преден адаптер и седиштето 


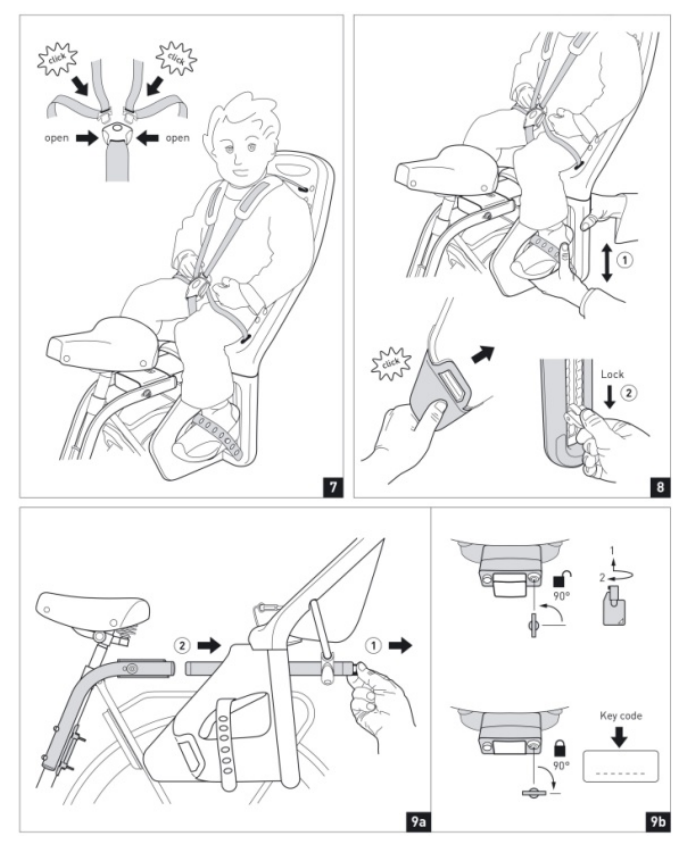

Слика 10.11 - Упатство за монтажа на седиштето на заден адаптер

\section{5 Избор на материјали}

Во поглед на ергономијата - нема компромис, таа треба да биде императив во секој модерен дизајн, со цел да се зачува здравјето на корисниците, а воедно и да се постигне успешен производ на пазарот. Никој не сака да купи столче кое е неудобно, уште помалку ако неговото дете треба да поминува подолго време во него. Освен ергономските димензии, развиените европски држави во денешно време големо внимание посветуваат на ергономските материјали, кои се подеднакво важни.

Во поглед на велосипедско седиште за превоз на деца, удобен материјал значи површина која не поти во лето, а во исто време не апсорбира топлина ако се остави на сонце, не се лади во зима, а во исто време е мек за седење, лесен за на велосипед и способен да ги амортизира ударите од нерамнините на патот. За таа намена најсоодветни се пенестите и сунѓерестите полимерни гуми. Разликата помеѓу нив е во хемискиот состав и молекуларната структура.

Материјалите имаат посебна улога во дизајнот на ова седиште, бидејќи се работи за склоп кој се очекува да биде што полесен, со оглед дека треба да биде поставен на велосипед, а во исто време и доволно јак за да ги издржи 
оптоварувањата од тежината на детето и да ги придуши вибрациите од нерамнините на патот.

Трите фррактали од седиштето и ободот на кацигата е предвидено да бидат направени од EVA полимер, спомнат во второто поглавје. Основата на делот за седење и делот за нозе, во вид на полимерна конструкција со дебелина од $2 \mathrm{~mm}$ ќе биде изработена од полипропилен со инјекционо пресување во алат. Истиот принцип би се применил и за држачите за стапала и за надворешниот дел од кацигата. Внатрешниот дел на кацигата треба да биде изработен од пенаст полимер, со специјални места предвидени за спојување со ободот. Метална конструкција би имало само под делот за седење, на местото предвидено за монтирање на седиштето со адаптерот на велосипедот.

\section{6 Бренд и лого}

Името на брендот го креирав според асоцијацијата на седиштето со фракталниот облик. Стратум на англиски значи слој, ниво. Логото е претставено на слика 10.12. Главната идеја која сакам тоа да ја претставува е минимализам, динамика, движење и брзина.

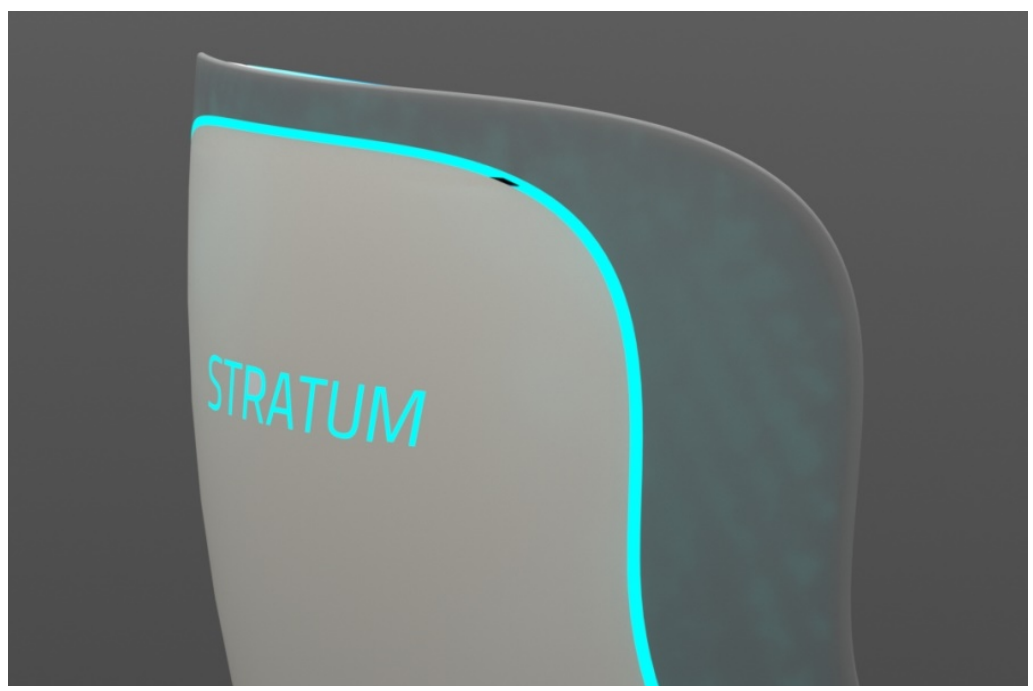

Слика 10.12 - Лого

\section{7 Стил}

Може да се каже дека дизајнот на овој производ претставува мешавина од повеќе стилови, од кои главно би се издвоиле футуризам, минимализам и органел (органски облици). Креирав седиште кое е модерно, изгледа 
футуристички, составено е од малку и едноставни елементи, и има чисти и јасни органски линии.

\section{8 Јазични фрункции (интердејс, симболички и естетски)}

Преку јазичните функции кај детското седиште е запазена комуникацијата на дизајнерот со корисникот, преку интерфејсот е овозможено лесно и достапно препознавање на главните потребни елементи, сигурносниот појас е интуитивен и лесен за употреба, копчето, логото и некои главни линии се обоени со фотосензитивна боја која преку ден се полни, а навечер свети со тиркизна неонска боја. Со нивна помош седиштето лесно може да се препознае навечер од страна на другите учесници во сообраќајот, што ја нагласува уште еднаш неговата безбедност. Секој фрактал е намерно обоен различно, за корисникот да може веднаш да распознае дека се работи за посебен слој кој и визуелно се одвојува од останатите.

Симболичката функција на дизајнот е претставена на неколку начини. Прво, преку името на седиштето - Stratum или strata на англиски значи слој, обвивка. Најчесто се однесува во контекст на слоевите кај карпите и земјината кора. Со нивно наизменично повторување природата создала прекрасни шарени колажи (слика 10.13).

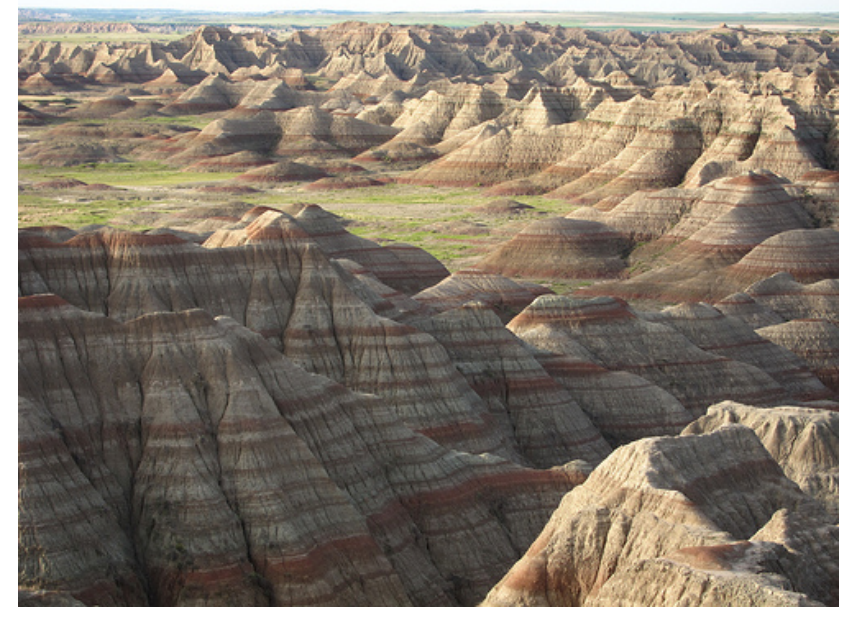

Слика 10.13- Инспирација за името, стратумите на земјината кора и карпите

Другата симболика се состои во едноставниот, но динамичен облик, кој асоцира на движење, дури и кога седиштето е во место. Тоа не е само одлика на дизајнот, туку се однесува и на мојот темперамент како дизајнер, негов креатор. Слободниот дух на велосипедот и движењето воопшто се најсликовит 
приказ на мојот темперамент. Седиштето ја симболизира и општо посветеноста на една мајка да го мотивира своето дете да ја засака природата и движењето низ неа.

Естетските функции се претставени како интегрирана целина меѓу примарниот облик, кој го претставува делот за седење и секундарниот облик оформен од делот за нозете. Заедно споени, даваат композиција која остава впечаток на една слеана фрорма. Сепак, немаше многу простор за експериментирање со формите, бидејќи ова е еден од оние дизајни каде формата мора да ја следи фрункцијата.

\section{9 Проверка на ергономијата и големината}

За крај, направена е контролна проверка на ергономијата и димензиите. На сликите 10.14 и 10.15 се претставени крајните горни возрасти на деца кои би го користеле седиштето: 1 година (), 3 години и 5 години. Може да се забележи на сл. 10.15 дека во првата варијанта монтирани се трите фрактали, додека на последната само едниот фрактал. За да се олесни визуелната споредба, седиштето на сите слики е со иста димензија.

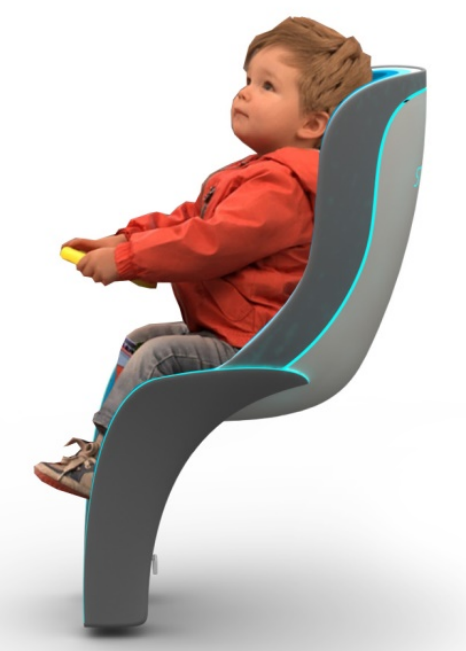

Слика 10.14 - Проверка на ергономијата и димензиите во поглед од страна (профил) 

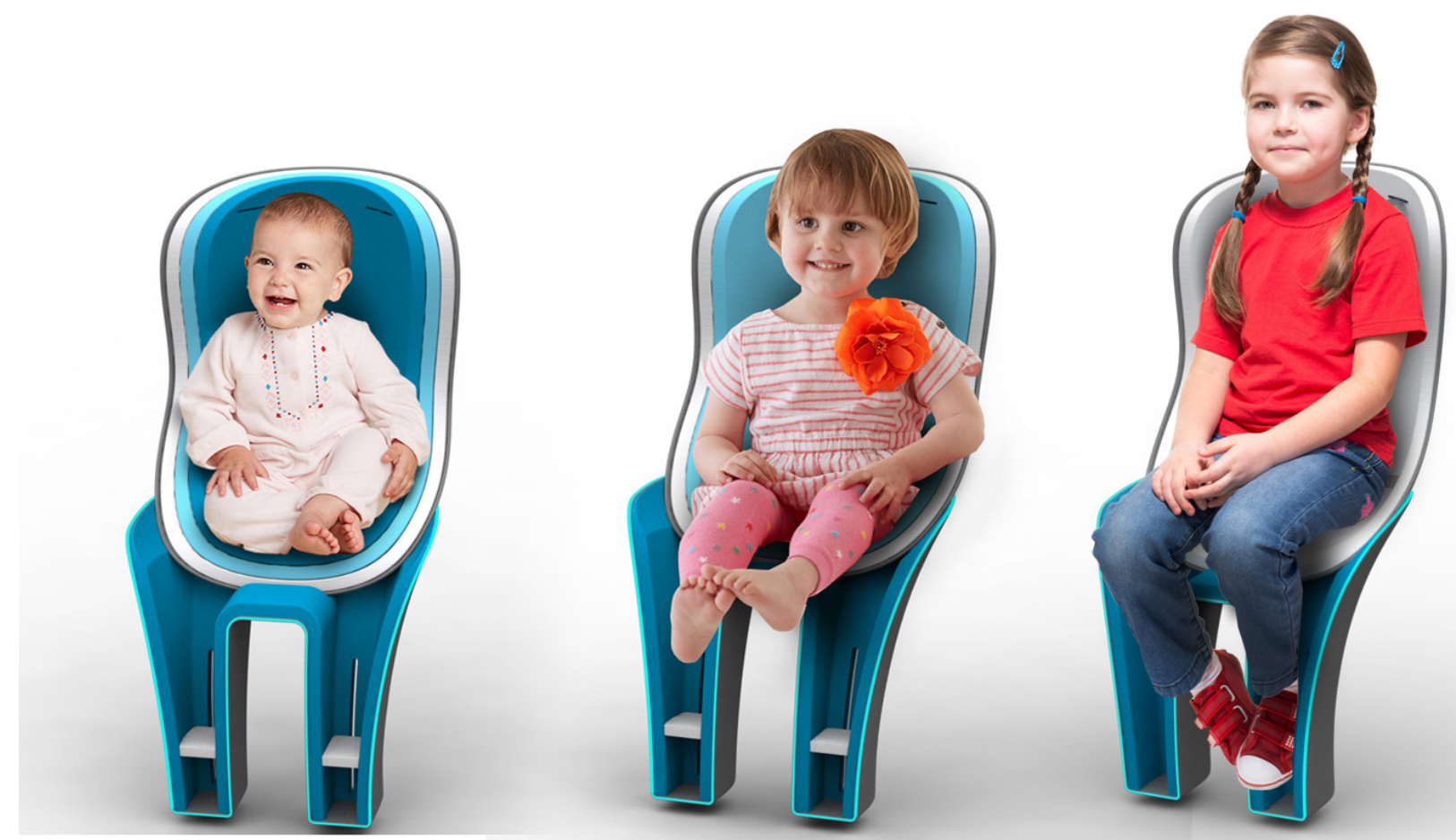

Слика 10.15 - Проверка на ергономијата на димензиите на трите слоеви одделно

Останува отворена опцијата удобноста и димензионирањето на седиштето да се провери во некој од расположивите софтвери за ергономија. Но, повеќето од нив се креирани за возрасни корисници, манекени. Како и да е, од овие слики може да се забележи дека главно се запазени клучните карактеристики во анатомскиот облик кон кој е насочен презентираниот дизајн на велосипедско седиште за превоз на деца. 


\section{1 Изработка на макета}

Детското седиште има сложен органски облик, што ја отежнува изработката на макета од глина или некој друг расположив материјал. Најдобра опција за изработка на моделот на седиштето беше примена на технологијата на 3D печатење. Дури и со овој нов компјутерски метод на принтање во простор, голем дел од деталите се изоставени, поради малите димензии на макетата. Овој модел е изработен во размер 1:5, заради ограничувањата на применетиот 3D принтер. 


\section{2 Заклучок}

Овој труд е фокусиран на интердисциплинарно истражување на можноста да се интегрираат биониката, како научна област на иднината, и ергономијата, која треба да претставува императив во секој модерен дизајн. Биониката е дефинитивно мојата омилена методологија која во последно време наоѓа голема примена во индустрискиот дизајн, бидејќ природата претставува неисцрпен извор на инспирација за мене како дизајнер. Се разбира дека антропометриските и ергономските истражувања, искуството со испитување на удобноста со сензори на притисок, истражувањето на пазарот, анкетирањето на таргет групата, беа неопходни за проучување на иновативниот пристап во адаптација на различни големини на производите во истражувачиот дел, како и за неговата проверка преку примената во редизајн на конкретен производ велосипедско седиште за превоз на деца.

Се надевам дека применетиот принцип на слоевити производи со цел постигнување адаптација на различни големини може да најде примена и кај други производи. Таков би бил примерот со сите видови седишта, особено оние кои заради безбедност треба да имаат конфигурација што поблиска на конфигурацијата на телото на корисникот. Сите тие, како и голем број производи кои се користат за различни корисници (скијачки чизми, заштитни обувки итн.) можат да бидат дизајнирани со примена на принципот на слоеви, презентиран во овој магистерски труд. 


\section{Користена литература}

[1] Carlos A. M. Versos, Denis A. Coelho, (2011) A Bi-Directional Method for Bionic Design with Examples, Universidade da Beira Interior, Portugal

[2] Jamshid Emami, Mahshid Tashakori and Zahra Tashakorina (2008), Bionic Design in Industrial Desing, Education at University of Tehran, Iran

[3] Neurohr R., Dragomirescu C., Bionics in Engineering - Defining new Goals in Engineering, University of Bucharest, Romania

[4] Carlos A. M. Versos, Denis A. Coelho, (2011) Biologically Inspired Design: Methods and Validation, Universidade da Beira Interior, Portugal

[5] Jamal Omari Wilson, (2008) A systematic approach to bio-inspired conceptual design, Dissertation at Georgia Institute of Technology, USA

[6] Arthur E. Stamps, (2002) Fractals, skylines, nature and beauty, Institute of Environmental Quality, San Francisco, USA

[7] Paul H. Carr, (2004) Does God play dice? Insights from the fractal geometry of nature, Zygon, vol 39, no.4

[8] L.P.A. Steenbekkers, (1993) Child development, design implications and accident prevention, Delft University press, Delft

[9] H. Witte, C. Schilling, Biological tissues and technical textiles:Analogies and applications via biomechatronics, IImenau University of Technology, Germany

[10] Mehdi Sadri, Mehdi Kavandi, Alireza Jozepiri, Sharareh Teimouri and Fatemeh Abbasi, (2014) Bionic Architecture, Forms and Constructions, Research Journal of Recent Sciences ,Vol. 3(3), 93-98

[11] Michael H. Dickinson, (1999) Bionics: Biological insight into mechanical design, Department of Organismal Biology, University of California, Berkeley, PNAS vol. 96, no. 25

[12] Vogel, S. (1988) Life's Devices, The Physical World of Plants and Animals (Princeton Univ. Press, Princeton, NJ) 
[13] Camila Freitas Salgueiredo, (2013) Modeling biological inspiration for innovative design, i3 Conference, University of Evry Val d'Essonne, France

[14] Colombo, B. (2008) Bionics Design as an Innovation Tool in the Product Design. World Universities Forum, Davos. Switzerland

[15] Kepler, J.A., Stokholm, M., (2004) Bionic Design Methods - A practical approach. International conference on advanced Engineering design, Glasgow, Scotland

[16] Paul van Geffen, Jasper Reenalda, Peter H. Veltink, Bart F.J.M. Koopman (2009), Decoupled pelvis adjustment to induce lumbar motion: A technique that controls low back load in sitting, International Journal of Industrial Ergonomics, 40 (2010) 47-54

[17] Haworth, (2004) The Ergonomic Seating Guide Handbook

[18] Rani Lueder, (2003) Rethinking sitting, ErgoSolutions, Humanics Ergonomics

[19] Mary Gale, An Opinion On The Theory Of Ergonomic Task Seating vs. The Facts

[20] Natalia Camprubí, Fernando Rueda, Iván Alonso, (2008) Evaluation of Foam Seats Using Realistic Simulation, Advanced Design \& Analysis Division, Centro Tecnológico Grupo CopoComfort

[21] Don B. Chaffin, (2007) Human Motion Simulation for Vehicle and Workplace Design, Human Factors and Ergonomics in Manufacturing, Vol. 17 (5) 475-484 Michigan, USA

[22] P.K. Nag, S. Pal, S.M. Kotadiya, A. Nag, K. Gosai, (2008) Humanseat interface analysis of upper and lower body weight distribution, International Journal of Industrial Ergonomics 38 539-545

[23] Norris, B. J. and Wilson, J. R., (1995), CHILDATA: The Handbook of Child Measurements and Capabilities - Data for Design Safety, Department of Trade and Industry, London, UK. 
[24] Jerom Usher, Gregory: (1997) Child's balance seat, US patent, Australia

[25] Lindbloom Betina (2014) Arrangement for adjusting the length of a carrying section of a child carrier, Babyldea OY, Helsinki, Finland

[26] R. Tilley Alvin, Dreyfuss Henry The Measure of Man and Woman: Human Factors in Design 1st edition, Associates

[27] Wiley John \& Sons Inc., edit by Salvendy Gavriel, (2012) Handbook of human factors and ergonomic, Fourth edition, Hoboken, New Jersey

\section{Користени веб - страници:}

[1] http://www.elastoproxy.com/en/blog/foam-rubber-vs-sponge-rubber-whatsdifferencel

[2] http://www.igmarston.com/rubber-product-materials.html

[3] http://www.industrialpolymers.com/products/flexible-molding-foam

[4] http://www.fastcodesign.com/1671543/an-ingenious-kids-seat-thatencourages-interaction

[5] http://www.dupont.com/products-and-services/plastics-polymersresins/thermoplastics/case-studies/flexible-plastic-in-seating.html

[6] http://www.h220430.jp/h220430 eva-chair-for-kids.html

[7] http://math.rice.edu/ lanius/frac/

[8] http://mathworld.wolfram.com/Fractal.html

[9] https://en.wikipedia.org/wiki/Fractal

[10] https://www.youtube.com/watch?v=xLgaoorsi9U

[11] https://www.pinterest.com/pin/439171401136596595/

[12] https://www.youtube.com/watch?v=-3pBuvfJseg

[13] https://www.pinterest.com/pin/214695107214427003/

[14] http://education.nationalgeographic.com/encyclopedia/bioluminescence/

[15] https://askabiologist.asu.edu/glow-dark-plankton

[16] http://www.theverge.com/2015/7/27/9045873/glowing-beach-bioluminescentplankton

[17] https://en.wikipedia.org/wiki/Luminous paint 


\section{Прилог A}

\section{Анкета за велосипедисти}

Анкета за потребите на магистерска работа по Индустриски дизајн и маркетинг за фрактален дизајн на детско седиште за велосипед

Колку често возите велосипед?

О секој ден

Неколку пати неделно

Неколку пати годишно

Не возам

Кога најчесто возите велосипед?

$\square$ Наутро

$\square$ Претпладне

$\square$ Попладне

Навечер

Дали сте возеле мало дете на велосипед?

Да

$\mathrm{OHe}$

Дали користите детско седиште за велосипед?

О да

$\mathrm{O} \mathrm{He}$

Дали мислите дека детско седиште за велосипед е исплатлива инвестиција?

Да

$\mathrm{OHe}$ 
Кој е клучниот критериум за купување на детско седиште ?

Цената

Безбедноста

Дизајнот

Носивоста

Тежината на седиштето

Лесна монтажа

Каков тип на седиште преферирате?

Предно (детето седи пред возачот)

Задно (детето седи зад возачот)

За која возраст на дете би одбрале седиште за велосипед?

до 2 години

О 2-4 години

над 4 години

Што според вас е најголемата предност на едно детско седиште за велосипед?

Можноста да се користи што е можно подолго

Атрактивен дизајн

Лесно качување и симнување со детето

Компатибилноста со различни велосипеди

Дизајн кој се монтира и како предно и како задно седиште

Што би подобриле во врска со детските седишта?

Издржливоста

Цената

Изгледот

Сигурносниот појас

Пол

О Машки

О Женски 


\section{Возраст}

О до 15 години

О 15-30 години

О 30-50 години

О над 50 години 